$1-1-1930$

\title{
Physiological Investigations on the Resistance of Peach Buds to Freezing Temperatures
}

\author{
H. L. Crane
}

Follow this and additional works at: https://researchrepository.wvu.edu/ wv_agricultural_and_forestry_experiment_station_bulletins

\section{Digital Commons Citation}

Crane, H. L., "Physiological Investigations on the Resistance of Peach Buds to Freezing Temperatures" (1930). West Virginia Agricultural and Forestry Experiment Station Bulletins. 236.

https://researchrepository.wvu.edu/wv_agricultural_and_forestry_experiment_station_bulletins/237 
West Virginia University Libraries

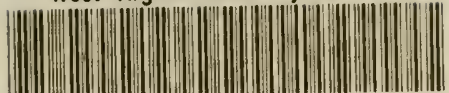

308021008961191 
West Virginia University Library

This book is due on the date indicated below.

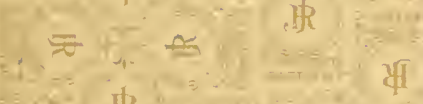

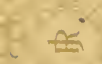


Digitized by the Internet Archive in 2010 with funding from Lyrasis Members and Sloan Foundation 


\section{Physiological Investigations on the Resistance of Peach Buds to Freezing Temperatures}

by H. L. GRANE

AGRICULTURAL EXPERIMENT STATION COLLEGE OF AGRICULTURE, WEST VIRGINIA UNIVERSITY 


\section{AGRICULTURAL EXPERIMENT STATION STAFF}

JOHN R. TURNER, Ph. D., LL. D., President of the University

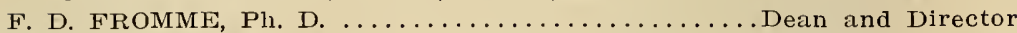
GERALD JENNY, M. S., Agricultural Editor....JOHN C. JOHNSTON, Chief Clerk

\section{AGRONOMY AND GENETICS}

R. J. Garbcr, Ph. D.

Agronomist and Geneticist

E. P. Deatrick, Ph. 1).

Associate Agronomist

W. H. Pierre, Ph. D.

Associate Agronomist

'T. C. McIlvaine, Ph. D.†

Assistant Agronomist

G. G. Pohlman, Pl. D.

Assistant Agronomist

M. M. Hoover, M. S.

Assistant Agronomist

H. K. Rowley, M. S. Agr.**

Seed Analyst

ANIMAL HUSBANDRY

E. A. Livesay, D. Sc.

Animal Husbandman

Chas. V. Wilson, M. S.

Assistant Animal Husbandman

J. H. Longwell. M. A.

Assistant Animal Husbandman

J. H. Rietz, D. V. M.

Associate Veterinarian

R. H. Tuckwiller, B. S. Agr.* Assistant Aninıar Husbandman

R. S. Glasscock, M. S.**

Assistant in Veternary Science

CHEMISTRY

R. B. Dustman, Ph. D

Agricultural Chemist

Chas. E. Weakley, Jr., M. A.

Assistant Chemist

L. P. Hansen, Ph. D.

T. B. Leith, M. S.**

Assistant Chemist

I. J. Duncan, B. S.

Assistant Chemist

Assistant in Agricultural Chenistry

DAIRY HUSBANDRY

H. O. Henderson, Ph. D.

Dairy Husbandman

I. M. Thurston, Ph. D.

Assistant Dairy Husbandman

K. S. Morrow, M. S.

Assistant Dairy Husbandman

L. F. Sutton, B. S. Agr.t

Assistant Dairy Husoandman

R. A. Ackerman, M. S. Agr.

Assistant in Dairy Husbandry

\section{ENTOMOLOGY}

I. M. Peairs, Ph. D.

W. E. Rumsey, B. S.**

State Entomologist

Edwin Gould, B. S. Agr. Assistant in Entomology

FARM ECONOMICS

A. J. Dadisman, Ph. L.

Farm Economist

F. D. Cornell, Jr., M. S.

Assistant Farm Mechanician

W. W. Armentrout, M. S.

Assistant Farm Economist

R. O. Stelzer, B. S.

Assistant in Farm Economics

HOME ECONOMICS

Rachel H. Colwell, M. A.

Home Economist

Hazel C. Cameron, M. A. Research Specialist in Nutrition HORTICULTURE

H. E. Knowlton, Ph. D.

Horticulturist

K. C. Westover, M. S. Agr.

Assistant Horticulturist

F. W. Craig, M. S. Agr.**

Assistant Horticulturist

I,eif Verner, M. S.

Assistant Horticulturist

M. B. Hoffman, M. S.

Assistant in Horticulture

E. N. McCubbin, M. A. Assistant in Horticulture

A, P. Dye, M. S. Agr.

Assistant in Horticilturc

PLANT PATHOLOGY

C. R. Orton, Ph. D.

Anthony Berg, M. S.

Plant Pathologist

Associate Plant Pathologist

L. H. Leonian, Ph. D. Associate Plant Pathologist

F. J. Schneiderhan, M. S. Associate Plant Pathologist

E. C. Sherwood, M. S. Assistant Plant Pathologist POULTRY HUSBANDRY

Horace Atwood, M. S. Agr.

Poultry Fiusbandman

T. B. Clark, B. S. Agr.

Assistant in Poultry Husbandry

*In cooperation with the U. S. Department of Agriculture, Washington, D. C.

In charge of the Lakin Sub-Station, Lakin, W. Va.

**In cooperation with the State Department of Agriculture, Charleston, W. Va,

$\ddagger$ In charge of the Reymann Memorial Farms, Wardensville, W. Va, 


\section{TABLE OF CONTENTS}

Page

Acknowledgements _...-_-

Introduction -_- - -

Theories in regard to freezing injury and resistance of plant tissue to low temperatures _..._- 6

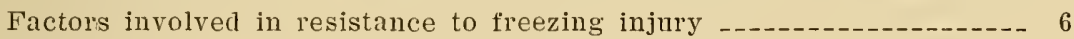

Environmental factor's that influence treezing injury _._._.

Characteristics of winters in West Virginia

Description and comparison of the varieties used _-_._._. 12

Materials and general methods _.......... 12

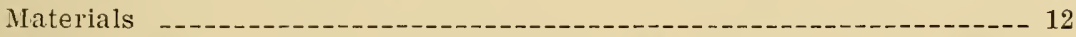

Methods used in determining the percentage of fruit-bud formation. and winter killing _..._. 13

Methods used in collecting samples for chemical analyses ............ 13

Methods used in determining dry weight and total nitrogen -.-_-_.-.-- 14

Methods used in the determination of carbohydrates _-_._._-_._._. 14

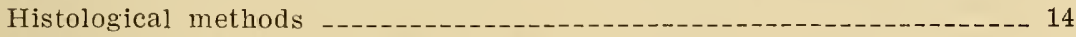

Mathematical significance of the data

PART 1.-The Influence of Pruning and Nitrogen Appiications on the Formation, Composition, and Hardiness of Peach Fruit Buds -......... 15

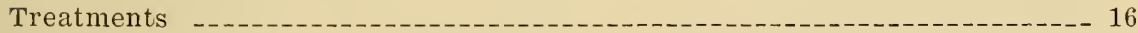

Experimental results _...

Growth response _..._-_-_._-_-_._- 18

Formation and hardiness of fruit buds _.

Formation of fruit buds _.

Hardiness of the buds -

Relation of length of shoot to the formation and hardiness of fruit buds 22

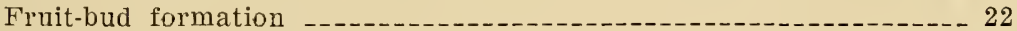

Hardiness of the buds _.

Dry weight of the fruit buds _-_-_._- 25

Bound water of the fruit buds

Size and increase in dry weight of the fruit buds _._._._._._._._._. 28

Percentage of total nitrogen in the fruit buds

Total nitrogen in one thousand fruit buds

Composition of the fruit buds

Discussion _-_.

PART II.-The Influence of Ringing and Nitrogen Applications on tire Formation, Composition, Growth, and Hardiness of Fruit Buds _...... 37 Treatments -

Experimental results _-_-_-_-_-_-_-_-_- 38

Growth response -_- 38 
Formation and hardiness of the fruit buds

Formation of fruit buds _.

Hardiness of the buds _-_._-_._- 42

Relation of length of shoot to the formation and hardiness of fruit budis 44

Dry weight of the fruit buds

Bound water of the fruit buds

Size and increase in dry weight of the fruit buds

Percentage of total nitrogen in the fruit buds

Total nitrogen in one thousand fruit buds _._.

Composition of the fruit buds _._. 51

Growth and development of the buds during the winter months _._._. 52

Increase in diameter of the naked fruit buds

Development of the pollen

Discusision -..--

PART III.-The Influence of Partial Defoliation and Nitrogen Applications on the Formation, Growth, and Hardiness of Peach Buds _._._._._. 57

Treatments _-_-_._- 57

Experimental results _._._._._- 58

Growth and blooming response of the trees following partial defoliation 58

Formation and hardiness of the fruit buds _... 60

Fruit-bud formation -

Hardiness of the buds _.

Dry weight of the fruit buds

Percentage of total nitrogen in the fruit buds _.......... 62

Total nitrogen in one thousand fruit buds

Growth and development of the fruit buds _._._. 64

Increase in diameter of the naked fruit buds

Development of pollen -

Discussion - -

General Discussion _-_-_- 71

Summary - -

Bibliography _-_.--

\section{ACKNOWLEDGMENT}

The writer wishes to acknowledge his indebtedness and to express appreciation and thanks to all who have assisted in any way in the conduct of this study; especially to Dr. Lewis Knudson, professor of plant physiology at Cornell University, under whose direction the problem has been carried out, for his most helpful and appreciated criticisms and suggestions; to the memiers of the Department of Agricultural Chemistry of West Virginia University for their cooperation and assistance, particularly to Dr. Lorenz Hansen, for making the carbohydrate analyses; to Messrs. C. E. Weakley and L. C. Shriver for making the totalnitrogen determinations. Thanks are also extended to Messrs. Allan Tenor and M. B. Hoffman, of the Department of Horticulture of the same institution, for their help in collecting samples and data. 


\section{Physiological Investigations on the Resistance of Peach Buds to Freezing Temperatures}

by H. L. CRANE $\dagger$

WHILE a considerable number of investigations have been made on the causes of injury by freezing temperatures, within more recent years attention has been devoted to the causes of resistance. The subject is not only of theoretical interest but of practical importance because of the great losses that result annually by freezing injury to the fruit buds of peach, plum, apple, cherry, and other fruit trees. The peach is particularly subject to damage by freezing and it is not uncommon to lose a season's crop because of death of the fruit buds by low temperatures. In addition to the killing of the fruit buds during those months when the plant is considered dormant, the essential floral organs may be killed by freezing temperatures when the trees are in flower. The latter may be controlled in part by heating methods. Generally speaking, loss from this late injury is less than from the killing of buds during the dormant season.

The killing of fruit buds during the dormant period varies with the variety. Experience as well as theoretical considerations also lead to the conviction that the resistance of the fruit buds to low temperature is determined in part by the character of growth of the tree during the season preceding the winter injury. It seems reasonable therefore to conclude that environmental conditions and cultural practices may influence the resistance to low temperature. While it is not possible to control the climatic factors, it is possible to control cultural practices. To a certain extent, therefore, resistance to low temperature may be increased when a fuller knowledge of the subject is available. With this purpose in mind the present investigation was undertaken.

This paper is the result of experiments conducted through a period of three years on the influence of cultural practices and other treatments on the hardiness of peach fruit buds of two varieties Salwey and Greensboro. In addition to the observations on resistance, chenical and histological studies were made in order to develop more precise knowledge concerning the growth and physiological changes related to resistance and susceptibility to low temperatures. In the main, three distinct treatments were followed. The first considers

$\doteqdot$ Resigned November, 1929. 
the influence of different kinds of pruning with and without nitrogen applications, the second considers the influence of ringing with and without nitrogen, and the third, partial defoliation with and without nitrogen. In addition, special consideration is given to the temperature relations prevailing in West Virginia during the winter months and to the bearing of these temperature conditions on freezing injury. A comparison is also made of the gross characters of the Salwey and Greensboro varieties, since the Greensboro is hardy, while the Salwey is readily injured by low temperature. Before considering the experimental work it will be desirable to consider briefly the views that have been proposed in respect to the characteristics of plants associated with resistance to freezing injury.

\section{THEORIES IN REGARD TO FREEZING INJURY AND RESISTANCE OF PLANT TISSUE TO LOW TEMPERATURES*}

\section{Factors Involved in Resistance to Freezing Injury}

Water content has been shown to affect the hardiness of plants. Working with peach buds Johnson (53) showed that the moisturedry weight ratio was an index of hardiness, as an increase in the ratio resulted in tender buds. Shutt (82) reported that twigs of hardy varieties of apples were low in moisture. The results of Beach and Allen (7), Strausbaugh (84), and Hildreth (46) agree with those of Shutt (82), although they found that shoots of hardy varieties after prolonged exposure to cold contain a higher percentage of water than the less hardy ones. This was due to the fact that tender varieties give up water more readily than hardy ones. Lott (59) found a marked correlation between the bound water and hardiness in brambles. Low moisture content is also a factor in the hardiness of wheat as reported by $\operatorname{Sinz}(83)$, Akerman and Johansson (2), Newton (69), and Martin (61), while Rosa ( $7 \%$ ) has indicated that this is true for certain. vegetable plants.

The imbibitional force of the cells was suggested by MuellerThurgau (66) as an important means of preventing the loss of water from the cells by freezing. Strausbaugh ( 84$)$, Newton (67), Dorsey and Strausbaugh (28), Dunn and Bakke (32), Lott (59), and Martin (61) hold similar views. Hooker (48) and Rosa $(y /)$ concur in this view and attribute the greater hardiness of hardened plants to a larger content of pentosans than is present in the non-hardened ones. Newton (69), Hildreth (46), Lott (59), Doyle and Clinch (29, 30), and Delong (27), however, found no consistent relation between pentosan content and hardiness.

*The literature dealing with the subjects of freezing injury and resistance of plant tissue to low temperature has been carefully reviewed by Chandler (16) Hildreth (46) Martin (61) and others. For this reason only a brief sketch of the ideas advanced which have a particular bearing on the problem at hand will be considered here. A rather complete bibliography, however, is included with this report. 
Maximow (62) and Chandler (16) studied the relation of sap) concentration to hardiness and found that the plant tissue showed a greater resistance to freezing than could be accounted for by the increased sap concentration. Ohlweiler ( $r 0)$ used a number of plant species and reported a relation between sap concentration and hardiness. These results were substantiated by Rosa (7y), Harvey (43), Carrick (11), Harris and Poponoe (42), Haas and Halma (41), and others. Winkler (93) showed that the cell sap of plants placed in cold chambers increased in osmotic concentration rather quickly. On the other hand, the work of Apelt (4), Rein (75), and Salmon and Fleming (79) showed no definite correlation between hardiness and osmotic concentration of the cell sap. Newton (68) properly points out that the osmotic concentration of the vacuolar sap contributes to the water-retaining power of the cells, but as an explanation of hardiness it is quite inadequate.

Molisch (63), was of the opinion that small cells contribute to hardiness. This view was supported by the work of D'Arsonval (25), Wiegand (92), and Rosa ( $7 y)$. Beach and Allen ( $r$ ) found no difference in the structure of apple stems of hardy and tender varieties, yet they thought hardiness was related to the hardness of the wood. On the other hand, the investigations of Rein (75), involving a large number of plant species, showed no relation between size of cells and hardiness. It should be pointed out that small, thick-walled cells are usually the result of slow growth, early maturity, and low nitrogen and high carbohydrate content which may be caused by a deficiency of water or nitrogen or by the lack of some essential element.

Schaffnit ( 80 ) concluded that as tissues are hardened, the proteins of the cells are split into simpler forms, less readily precipitated than those of non-hardened tissue. Harvey (43) found that on hardening herbaceous plants the amino nitrogen increases greatly, and that the simpler forms of proteins are not so easily precipitated by freezing or by the addition of acids as the more complex forms. Newton (69), working with wheat, and Hildreth (46), with apples, found that the ratio of amino to total nitrogen increases in the fall but that no consistent relationship exists between amino nitrogen and hardiness.

\section{Environmental Factors That Influence Freezing Injury}

Maturity has been shown to be of paramount importance in determining the degree of cold resistance of plants. Emerson (34) believed that resistance to cold in fruit trees often was due almost wholly to the habit of early maturity rather than to constitutional hardiness, and Macoun (60) came to the conclusion that trees or shrubs to survive severe winters must ripen their wood early. Emery (35) pointed out that temperatures well above $0^{\circ} \mathrm{F}$. in early winter often cause more injury than $-30^{\circ}$ or $-40^{\circ}$ later. Green and Ballou (39) report that peach trees growing in rich, moist soil or under late cul- 
tivation were more severely injured because of immaturity than similar trees growing in sod or under grass mulch. Emerson (33) found a similar relationship. Thayer (87) found that young peach trees, because of their late growth, bear more tender fruit buds than the older trees that have a shorter duration of growth. Gladwin (36) reports that severe pruning of grapes decreased the hardiness of the wood and buds by delaying maturity. Bradford and Cardinell (12) say that lack of maturity is the greatest factor in inducing winter injury, and that late cultivation or heavy fertilization have proved to be unwise practices.

Because of differences in the degree of maturity in early winter, plants normally hardy may in certain instances be more susceptible to freezing injury than less hardy ones. Such conditions have been reported by Blake and Farley (9), Greene (40), Bradford (11), Chandler (17), and others.

It has been reported by several investigators that by mid-winter the condition or state of hardiness may be lost, at least to some degree. The studies of Askenasy (5) with sweet cherry and those of Knowlton and Dorsey (56) with peaches showed that the fruit buds make a continuous growth and development from fall until spring. Whitten (90), Howard (50), Chandler (15), and Hooker (49) have pointed out that the growth of the buds during the warm weather of the winter made them particularly susceptible to injury by freezing temperatures. Blake and Connors (10) report that Elberta and other similar varieties start into growth the first warm days in the winter and later are severely injured, while such varieties as Carman and Greensboro respond less quickly and escape with slight damage. Davis (26) has shown that sour cherry buds having withstood temperatures of $-30^{\circ} \mathrm{F}$. during January without injury were killed by much higher temperatures in late February and early March. The critical temperature depends on the degree of maturity in earìy winter and on the stage of development of the buds in late winter, as has been pointed out by Howard (50) and by West and Edlefsen (89).

Another important factor in determining the injury resulting fron a certain temperature is the rate of temperature fall. Chandler (16) reports that when peach buds were cooled rapidly to $-17^{\circ} \mathrm{C}$., from 97 to 100 percent were killed, but when they were cooled slowly to $-19.5^{\circ} \mathrm{C}$., only 15 to 18 percent were killed. Similar resuits for apple roots and shoots have been shown by Carrick (13), Potter ( 73 ), and Hildreth (46). The greater injury resulting from a rapid fall in temperature is of particular significance for sections like West Virginia, which are subject to rather sudden and wide deviations in the daily minimum temperatures during the winter.

The length of the rest period has been emphasized by Strausbatigh (84) as important in determining the relative hardiness of plum varieties. Chandler (15) suggested that by prolonging the period of growth of peach trees by late cultivation, by pruning, or by fertili- 


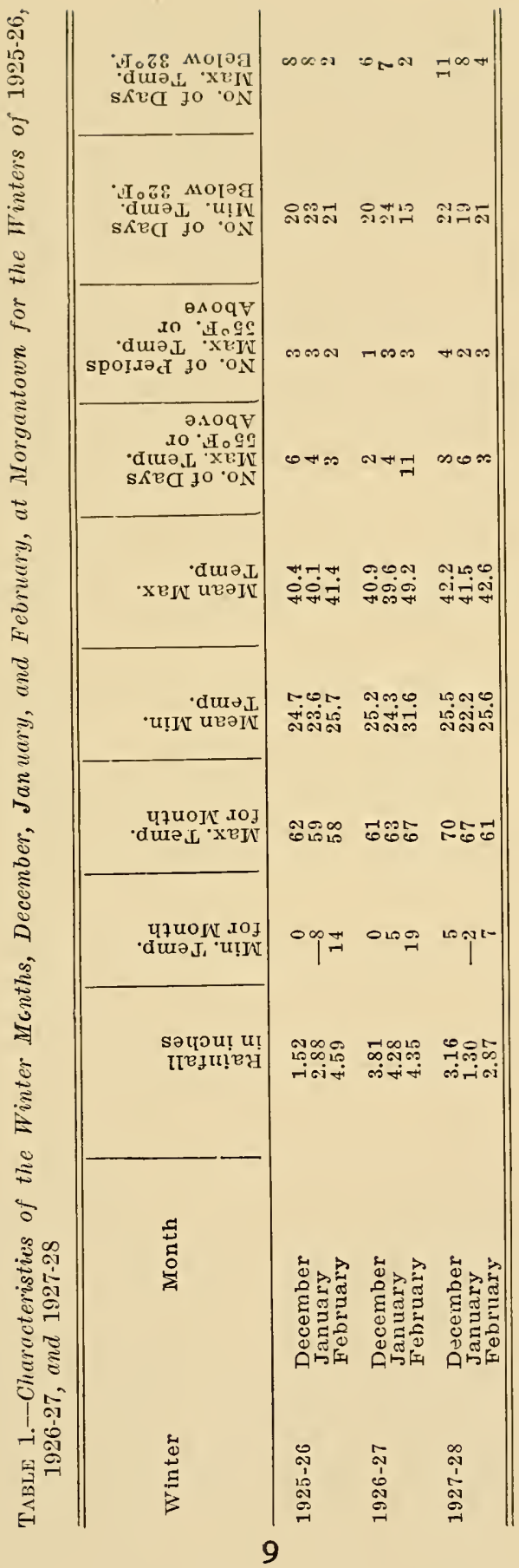


zation, the entrance of the trees into the rest condition would be delayed and consequently they would come out of it later in the winter. As a result, when the rest was initiated later, the buds would make less growth in the warm days of winter and would be more resistant to the low temperatures occurring in the spring. The evidence presented by Howard (51), Johnson (54), Hodson (47), and Knowlton and Dorsey (56) show that the rest period in peaches is over by early January, and thus it could not have a restraining influence on the growth of the buds during late winter.

A consideration of the evidence on freezing injury reveals that the state or composition of the protoplasm is the critical factor in resistance. The observations of others previously discussed reveal likewise that what is commonly termed maturity predetermines the relative resistance of the plant to freezing temperatures. Maturity of woody plants means that cellular activity in relation to growth is at a minimum point, water content is low, the reserve foods are of high molecular weight, and cell wall thickening has been entirely completed. Since these are the characteristics of the resting condition, the inference seems permissible that the plant in that condition is less susceptible to freezing temperatures.

\section{Characteristics of Winters in West Virginia}

It is apparent that other factors as well as temperature are involved. For a clearer understanding of the problem and to define certain conditions of the experiment, consideration must be given to the temperatures prevailing at Morgantown, West Virginia.

The winters in the latitude of West Virginia are mild and open. Usually there are one or more periods when the temperature may remain well above the freezing point for several days. These warm periods are followed in many instances by a rapid drop in temperature-close to $0^{\circ} \mathrm{F}$. These conditions generally cause the winter killing of the fruit buds. Knowlton and Dorsey (56) report that late in January, 1925, nearly all buds of the tender and semi-hardy peach varieties in the orchard of the Experiment Station at Morgantown were killed after a warm period followed by a sudden drop in temperature to $-9^{\circ}$. During the fall the weather is generally warm, sunny, and favorable for late growth of the trees. In an occasional winter like that of $1918-19$, serious damage may result to the trees and fruit buds if the temperature approaches $0^{\circ}$ before maturity has developed. Such occurrences are, however, infrequent.

The winter of 1925-26 caused severe winter killing of peach buds, especially those of tender varieties. In Table 1 are given the maximum and minimum temperatures from December to February inclusive. These data show that a maximum temperature of $55^{\circ} \mathrm{F}$. or higher occurred 8 times during the months of December, January, and February. The minimum temperature for the winter was $-8^{\circ}$ on Jan- 
wary 29. This temperature was sufficiently low to kill all of the Salwey buds and from one-half to three-fourths of the Greensboro buds on trees in the experinents to be reported later. On January 16 the maximum temperature reached $57^{\circ}$. The weather remained warm for a week, with the minimum temperature well above freezing for five days. This was followed by a colder period, then by a slight rise in temperature, and finally the drop to $-8^{\circ}$.

The winter of 1926-27 was mild and the minimum temperature was $0^{\circ} \mathrm{F}$. on December 18 . Temperatures of $5^{\circ}$ were recorded on Jannary 16 and 27 . Immediately preceding the fall in temperature on January 27, the maximum temperature was as high as $63^{\circ}$, with the minimum temperature well above freezing for several days. No fruit buds were killed by the $0^{\circ}$ temperature of December 18 , but the temperature of $5^{\circ}$ on January 27 caused the death of about 25 percent of the Salwey buds.

Following an exceptionally late, warm, and wet October and November, the winter months of December, January, and February of 1927-28 were drier than normally. The minimum temperature for December was $5^{\circ} \mathrm{F}$. It occurred on the night of December 9, immediately after a warm period, during which the maximum temperature was $62^{\circ}$ on the seventh. This temperature killed a small percentage of the buds of the Salwey. The minimum temperature of $-2^{\circ}$ for the winter occurred on January 2, immediately following a warm period of three days wherein the maximum temperature ranged from $54^{\circ}$ to $57^{\circ}$ and the minimum temperature from $33^{\circ}$ to $52^{\circ}$. The minimum temperature of $-2^{\circ}$ caused considerable injury to the fruit buds of both Greensboro and Salwey varieties.

February was considerably warmer and drier than usual, and was followed by a March colder than the average. It was, however, unusually warm for three days from March 11 to 13 , when the maximum temperature varied from $60^{\circ}$ to $80^{\circ} \mathrm{F}$. and the minimum temperature from $32^{\circ}$ to $50^{\circ}$. This was followed by a minimum temperature of $23^{\circ}$ on March 17 , which killed a rather large percentage of the pistils of certain fruit buds of the Salwey and a few of the Greensboro.

The fact that the greatest damage results when wide fluctuations in temperature occur, as, for example, a change from $55^{\circ}$ or $60^{\circ}$ to $0^{\circ}$ or $10^{\circ} \mathrm{F}$. within a few days, is of great significance. This implies that during the winter and early spring, protoplasmic changes are induced, at least in part, by the high temperatures, making the plant tissue particularly susceptible to injury and death by temperatures below the freezing point. A knowledge of these changes would of course contribute to a clearer understanding of the causes of death by freezing temperatures. The relation of these temperature fluctuations to freezing injury will be considered subsequently in the various experiments and discussion. 


\section{DESCRIPTION AND COMPARISON OF THE VARIETIES}

Hardiness is determined to a considerable degree by the protoplasmic activity or growth response of the tissues during the warm periods in mid-winter. For these reasons it seemed desirable to make a careful study of the growth behavior and certain chemical characteristics of two markedly different varieties of peach, both growing under the same conditions. One of these varieties, the Salwey, usually is quite susceptible to injury by freezing temperatures; the other, Greensboro, is strikingly resistant. Since low temperatures affect these varieties quite differently, it was thought that a comparison of the two would reveal data not only of theoretical importance but of practical value in formulating possible corrective cultural methods.

A comparison of Greensboro and Salwey as regards growth and fruiting characteristics is significant. Both varieties are vigorous in growth, and they produce large trees. The Greensboro has an open, spreading top, while that of the Salwey is upright, spreading and becoming drooping and dense. The Greensboro normally produces many short, thick, spur-like shoots, while the Salwey bears a much smaller number of such growths, and these usually are longer and more slender. The Greensboro makes its growth early in the season. Usually growth elongation stops, and fruit-bud initiation begins about a month before that of the Salwey. Under West Virginia conditions the fruit of the Greensboro matures from the middle to the last of July, while the Salwey does not ripen until the middle to the last of September. The fruit buds of the Greensboro are large as compared to those of the Salwey. This greater size of the Greensboro buds is due to a larger number of bud scales, heavier pubescence, and a larger bud cavity than in the case of the Salwey. Both varieties bloom at approximately the same time.

\section{MATERIALS AND GENERAL METHODS}

\section{Materials}

The orchard used in these investigations, located at Morgantown, was planted in the spring of 1916, consisting of $\delta$ rows of 15 trees planted diagonally, 16 by 26 feet apart. Cultivation usually was started about the time of bloom and was of sufficient frequency to prevent weed growth. In June soybeans were sown and an application of 300 to 400 pounds of 16-percent superphosphate was made. When the soybeans had attained their maximum developinent they were disked down, and a cover crop of rye was seeded. No nitrogencarrying fertilizers were applied until the spring of 1924, when a four-pound application of nitrate of soda was made at the time of flowering to alternate trees in each row; these same trees received the same amounts of nitrate of soda in the years following. 
Three trees of eacl variety, sclected as far as possible for uniformity of size, rigor, and growth response, were used in each treatment.

During the course of these studies the only fruit produced was in the summer of 1926, when the Greensboro bore a light crop.

\section{Methods Used in Determining the Percentage of Fruit-Bud Formation and Winter Killing}

The number of fruit buds formed and the total amount of winter killing was determined when the buds were in the pink stage.

Each winter after a particularly cold night or a hard freeze following a warm period the orchard was visited. Observations were made on the injury to the buds, - none, however, until the weather had become sufficiently warm after the cold period for the buds to have thawed completely and turned brown. Buds at this time were sectioned and examined macroscopically for injury.

In determining the percentage of fruit-bud formation and of hardiness, only unblanched shoots were used. The length of the shoot was measured, and the number of nodes and buds for the shoot counted; likewise the number of buds which from outside appearances were alive and would open normally into full bloom. In the spring of 1928 certain treatments showed a considerable number of buds with their pistils killed. In this case a separate count was made of those injured. In calculating the percentage of fruit buds formed it was considered that, as a maximum, two fruit buds should be formed at each node. Hence the number of buds was divided by two times the number of nodes and the result was multiplied by 100 . The percentage of live buds was calculated from the number formed and the number alive. To obtain these data 30 to 70 shoots from each tree were used. These shoots were taken promiscuously from all parts of the trees in an attempt to get a random sample.

\section{Methods Used in Collecting Samples for Chemical Analyses}

All samples of buds for dry weight, nitrogen, and carbohydrate analyses were collected in the morning, usually from 9 to 10 o'clock, on clear days. Representative one-year, unbranched shoots of about 10 to 15 inches in length from all parts of the tree were cut, tied in a bundle, labeled, placed in a collecting can, and taken to the laboratory as soon as all samples were collected. An attempt was made to collect the samples in the field in weighing bottles. This had to be discontinued because of the slowness of the operation. A comparison of the two methods of taking samples was made, and the laboratory method gave the more uniform results. The buds were removed from the shoots with approximately the same amount of scales, bark, and wood. The buds in each sample were counted when removed and were placed in open Petri dishes, in which they were dried. All of the fruit buds from each shoot were included in the sample. For the dry weight and nitrogen determinations, samples were taken from each of the three trees in each treatment, and the analyses made separately. 


\section{Methods Used in Determining Dry Weight and Total Nitrogen}

The fruit buds were dried just as they were removed from the shoots. For the dry weight determinations a sample of two to three $\mathrm{gm}$. or about 200 buds were used. These were first dried in a constant temperature oven at $30^{\circ} \mathrm{C}$. for $1+14$ hours. It was found by trial that at this temperature and for this time the samples reached constant weight. To determine the amount of bound water or that held tenaciously by the buds, the samples were again dried for 72 hours in vacuo at $70^{\circ} \mathrm{C}$. with a vacuum of 26 to 27 inches of mercury. The entire samples were then used for the total nitrogen determinations which were made by the official Kjeldahl-Gunning-Arnold method.

\section{Methods Used in the Determination of Carbohydrates}

Because of the nature of the material the samples were small, and from 6 to $14 \mathrm{gm}$. green weight were used for the carbohydrate analyses. Each sample of buds was placed in a jar thoroughly mixed by shaking, and about two gm. of the material was removed for dry weight and total nitrogen determinations. The remaining 4 to $12 \mathrm{gm}$. of buds were weighed, giving total green weight. The samples were prepared as quickly as possible, covered with 95 percent alcohol, a small quantity of calcium carbonate added, and heated at $70^{\circ} \mathrm{C}$. for one hour. The methods of analysis were as follows: the alcohol was evaporated off the samples in vacuo at $75^{\circ} \mathrm{C}$. The dry material was then extracted with ether in a Soxhlet extraction apparatus for approximately 12 hours, giving the ether soluble material. The residue was then extracted with 80 percent alcohol in a manner similar to the ether extraction. The alcohol solution was made up to volume and an aliquot portion taken for (a) determination of reducing sugars and (b) total sugars. The residue from the alcohol extraction was dried in an oven in vacuo at $75^{\circ} \mathrm{C}$. for approximately 12 hours. Samples were taken for starch determinations and the residue from this was analyzed for acid hydrolyzable materials. Methods used for the analysis of reducing sugars, total sugars, starch, and acid hydrolyzable (hemi-cellulose) were those of the Association of Official Agricultural Chemists.

\section{Histological Methods}

During the winter of 1927-28 the development of the buds was followed by histological methods. Two collections of buds were made, the first on November 29, the second on February 6. Samples were killed and fixed from eight different treatments of each of the two varieties. In collecting the material, uniform shoots of 12 to 15 inches long were cut from various locations on two of the three trees in each treatment. The buds from these shoots were separated into two samples: basal and terminal buds. In taking the sample of the basal buds those borne on the first three or four nodes were dis- 
carded because of the small leaves ustually borne at these nodes. The buds used in the basal sample were taken from the fourth to seventh nodes from the base of the shoot. The buds comprising the terminal samples were taken from the last five or six nodes on each shoot, none being discarded. Schaffner's chrom-acetic fixative and the paraffin method of embedding were used. The material was sectioned from five to ten microns thick and stained with Fleming's triple stain. In all over $S 00$ slides were made for these studies. 'Two measures of growth were used in following the growth of the buds during the winter months: the diameter increase of the buds measured through the ovule case, and the development of the pollen. In all instances the most advanced degree of pollen development found in the various anthers of each bud was used as the stage of development for that butcl.

\section{Mathematical Significance of the Data}

In some cases in which the mean of a series of results is given the probable error has been calculated, using Bessel's formula.

It is realized that in most groups the population was small and not distributed normally. The error as calculated, therefore, is not a true error, but it is included in the cases where it seemed warranted in order to call attention to the probable significance of the data and to prevent the drawing of conclusions not justified. Where comparisons are made the odds as to the significance of a difference have been calculated by the use of Pearson's (71) tables, from the ratio of the observed differences to the error of the difference as calculated by the usual formula. In some cases the correlation coefficient has been calculated to show the relationship between characters by the ustual formula as applied to the short method.

\section{PART I}

\section{The Influence of Pruning and Nitrogen Applications on the Formation, Composition, and Hardiness of Peach Fruit Buds}

Hardiness is related to maturity of the tissue. It is probable, therefore, that cultural practices which delay or hasten the maturation of tissues have an influence on their resistance to freezing temperatures. For this reason experiments were made to determine the influence on hardiness of two practical procedures: namely, pruning and the use of nitrate of soda. Numerous experiments have shown that these practices, within limits, stimulate the growth of the trees somewhat in proportion to the severity of the pruning or to the amount of nitrate of soda applied. The growth response following such treatments is determined to some extent by the vigor of the trees. For this reason every precaution was taken to use trees of uniform size and vigor. 


\section{Treatments}

The object of the treatments employed was to alter the carbohydrate-nitrogen relationships and the growth of the trees so that their effects on the hardiness of the fruit buds could be determined. In the spring of 1925 the trees of every other row in the orchard already described were headed back so that the main scaffold limbs were four feet long, and those of the alternate rows were cut back to two feet. Certain rows received one, two, and three summer prunings. The first summer pruning was made June 18, when the new shoots were about one foot long. It consisted of removing the excess shoots. The second summer pruning was given July 20. As before, the excess shoots were removed, and those which had grown beyond the general contour of the tree were headed back. The third summer pruning was given August 14, of the same nature as the second. The effects of these treatments on the growth of the trees has been reported (21).

The following spring (1926) all of the trees, excepting those of Row 31, which were used as checks, and the Salwey trees of Row 27 , were very lightly pruned in late winter (corrective pruning). Very little wood was removed, as only interfering shoots or those which had grown beyond the general contour of the tree were removed or cut back. The Salwey trees of Row 27 again were pruned twice during the early summer, at approximately the same time and in the same manner as the first two summer prunings of the previous year. A four-pound application of nitrate of soda was made each spring at the time of blooming to alternate trees in each row as already mentioned. Briefly, the above and subsequent treatments were as follows :

Row 25. Greensboro: 1925, Light dormant and one summer pruning not used after the spring of 1926.

Row 27. Greensboro: 1925, Light dormant and two summer prunings. 1926 and 1927, Corrective pruning.

Salwey: 1925, Light dormant and two summer prunings. 1926, Corrective and two summer prunings. 1927, Corrective pruning.

Row 29. Greensboro: 1925, Light dormant and three summer prunings; 1926, Corrective pruning and every other tree received 16 pounds of nitrate of soda applied in four equal applications on April 30, June 9, June 24 , and July 15. These trees were not used after the spring of 1927.

Row 31. Greensboro: 1925, Light dormant pruning; 1926 and 1927, no treatment. These trees were used as the checks. Salwey: Same as the Greensboro.

Row 32. Greensboro: 1925, Heavy dormant pruning. These trees were not used after the spring of 1926. 


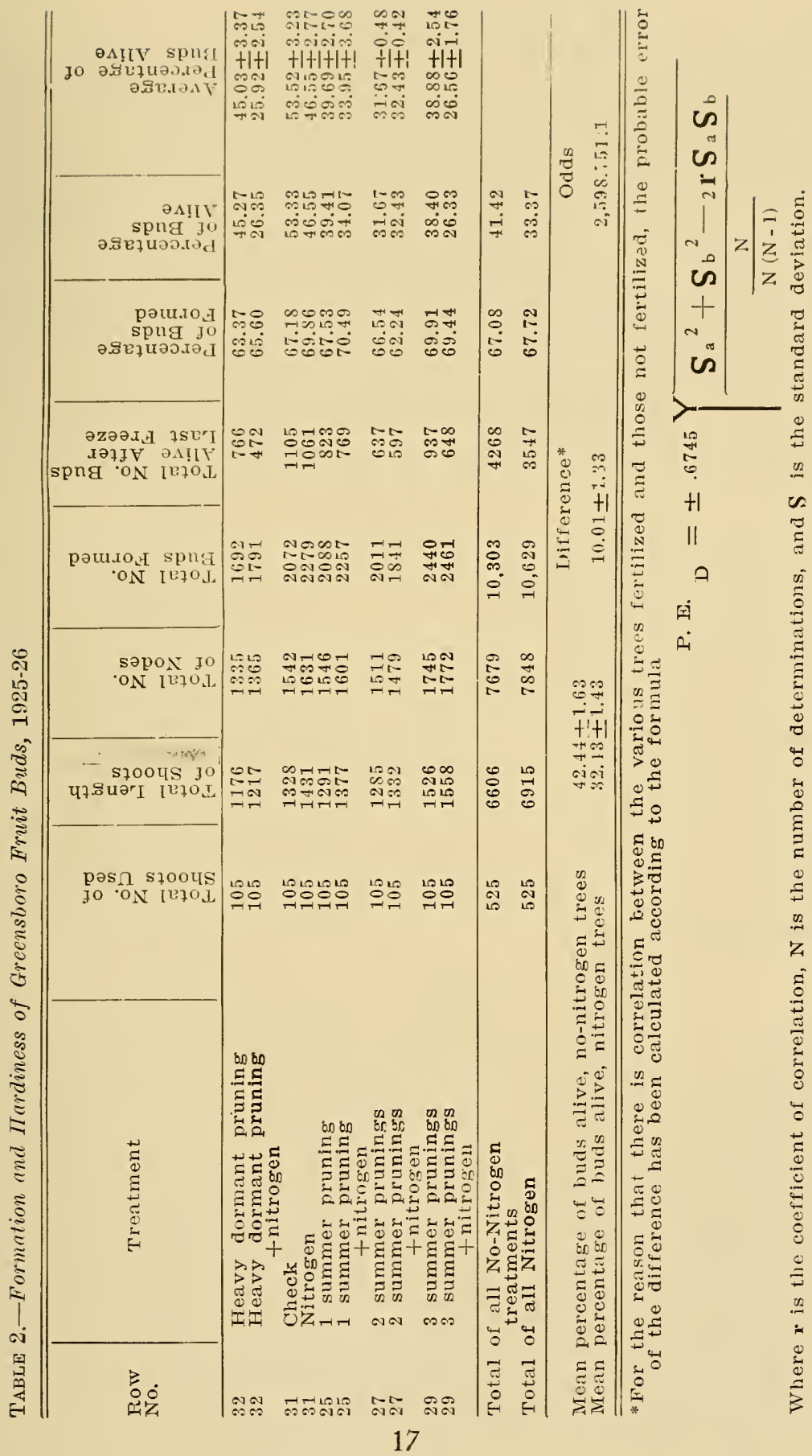




\section{EXPERIMENTAL RESULTS}

Since pruning or the application of nitrogen influences the growth of the trees it was expected that not only the hardiness but the formation of fruit buds would be affected by these practices. For this reason the percentage of buds formed as well as those killed was deternined by the methods already described. The peach produces the fruit buds on wood of the current season. For this reason emphasis has been placed on the relation of the length of the shoot on which the buds are borne to their formation and hardiness.

To determine whether the growth made by the trees in the season the fruit buds were formed had any influence on the composition and hardiness of the buds, determinations were made of the dry weight, bound water, total nitrogen, seasonal changes of these factors, and the carbohydrate content of the buds. The increase in dry weight of 100 buds and the gain in total nitrogen have been used as measures of the development of the buds during the winter months.

\section{Growth Response}

Following the pruning or nitrogen treatments of the spring of 1925, the growth of new shoots was greatly stimulated. In the case of the trees which received two or three summer prunings the growth response was not proportional to the severity of the pruning or to the amount of nitrogen available to the trees. The length of the shoots of the trees that were summer-pruned two or three times was little different from those summer-pruned once. However, the continued pruning reduced the leaf area so that carbohydrates were probably limiting. This is indicated by the long and slender roots produced which formed few secondary branches. The application of nitrate of soda greatly stimulated the growth of the trees, causing more and longer shoots to be formed and the leaves to be darker green in color and to be retained longer than those of similar trees not fertilized.

\section{Formation and Hardiness of Fruit Buds}

In Tables 2 and 3 are given the results on the formation and hardiness of the fruit buds for the seasons of 1925-26 and 1926-27, respectively. As regards the formation of fruit buds or, as it is commonly termed, the setting of fruit buds, the data are not wholly in agreement.

\section{Formation of Fruit Buds}

The formation of fruit buds on the Greensboro was not influenced by pruning or nitrogen applications to any appreciable extent during the season of 1925-26. (See Table 2.) This was rather surprising in view of the wide vegetative difference of the trees in the various treatments. The data for the season of 1926-27 (Table 3) show that the application of nitrogen seemed to increase fruit-bud formation on the Salwey but to decrease it on the Greensboro. When the Salwey trees were summer-pruned the formation of fruit buds 


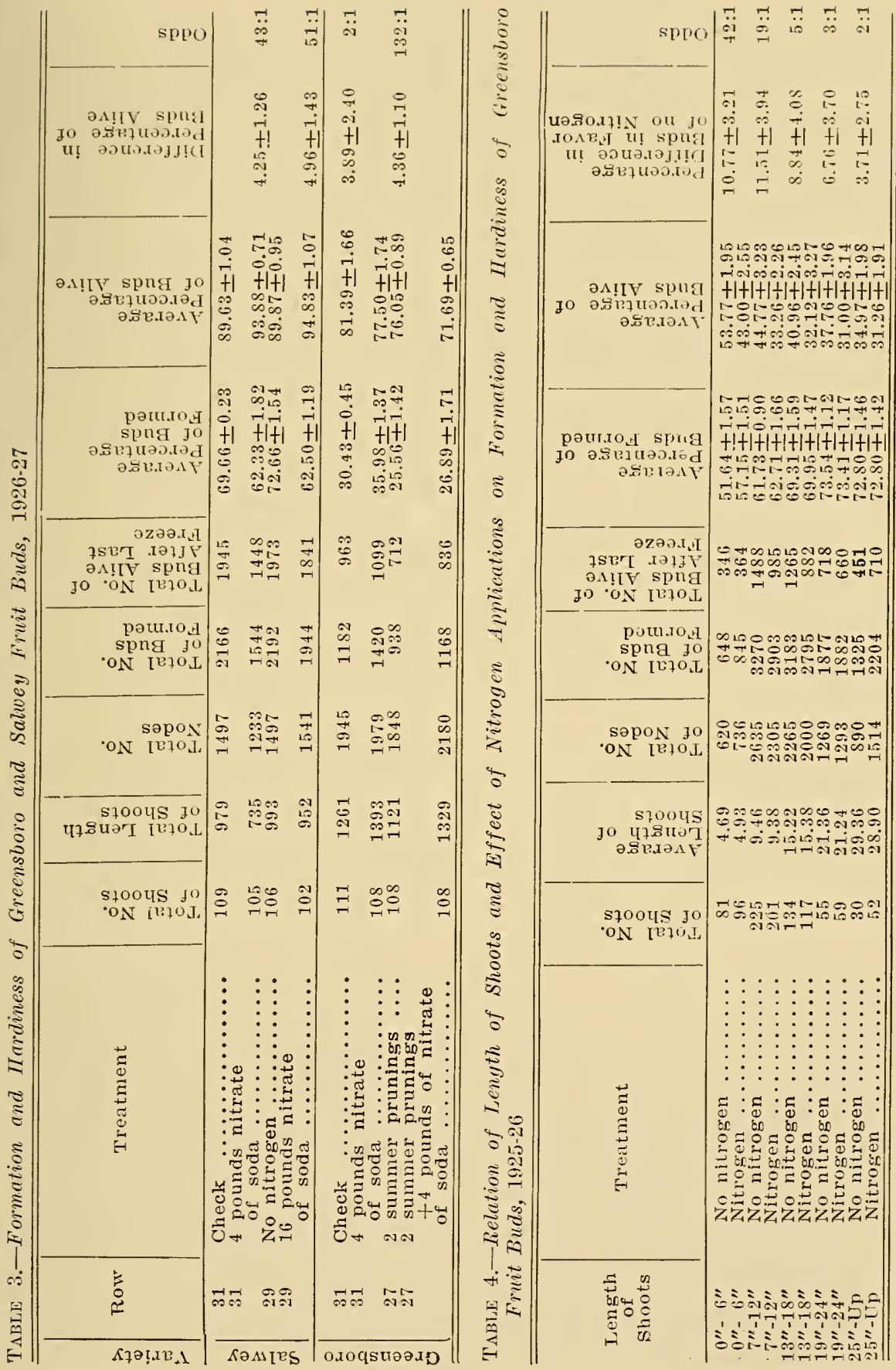


was reduced on the shoots of all lengths as compared with the checks. Nitrogen applications had no effect on the formation of fruit buds when applied to summer-pruned trees. It is believed that summerpruning stimulated tree growth and reduced the leaf area to such an extent that carbohydrates limited the formation of buds by the Salwey trees.

\section{Hardiness of the Buds}

The extent of winter-killing of the Greensboro fruit buds during the winter of 1925-26 seemed to be related to the growth of the trees during the previous growing season (Table 2). It appears that the conditions which promoted the growth of the trees caused the buds to be susceptible to winter-killing. The data of Table 2 show some striking relations between the severity of the pruning or nitrogen applications and the ability of the buds to withstand winter conditions. The trees producing the hardiest buds were the checks. When a four-pound application of nitrate of soda was made to similar trees the hardiness of the buds slightly decreased.

The trees pruned severely in the dormant season produced buds about as susceptible to injury from low temperatures as those which had received the lighter pruning and nitrate of soda. When nitrate of soda was applied to similarly heavily-pruned trees the buds were still more tender. One summer-pruning reduced the hardiness of the buds more than the heavy dormant pruning, and when nitrate of soda was applied they were less hardy. Continued summer pruning caused the buds to be very tender.

The degree of severity or the time of pruning apparently had a greater effect on the hardiness of the buds than the application of nitrogen. In some instances the differences in hardiness of the buds of the trees which did and did not receive nitrogen are not significant; in others, however, they are. When the hardiness of the buds of all the fertilized trees is compared with those not fertilized, the former were significantly more tender.

During the winter of 1926-27 studies on the hardiness of the Greensboro buds were confined to the effects of nitrogen applications. Very little injury to the buds occurred during the vinter. Table 3 shows that the nitrogen applications caused the buds to be hardier than those on trees not fertilized. The differences are small and they are the exact opposite of what was found the previous winter. It would seem that this disagreement may be accounted for through the effects of the crop of fruit produced by the trees in the summer when the buds were formed.

The trees fertilized the previous year (1925) were larger in size and had darker green and healthier foliage than those not nitrated. The fertilized trees suffered greater injury to the fruit buds in the winter of 1925-26, with the result that there were less flowers to open and less fruit to set and mature per unit of wood than on the unfertilized trees. 


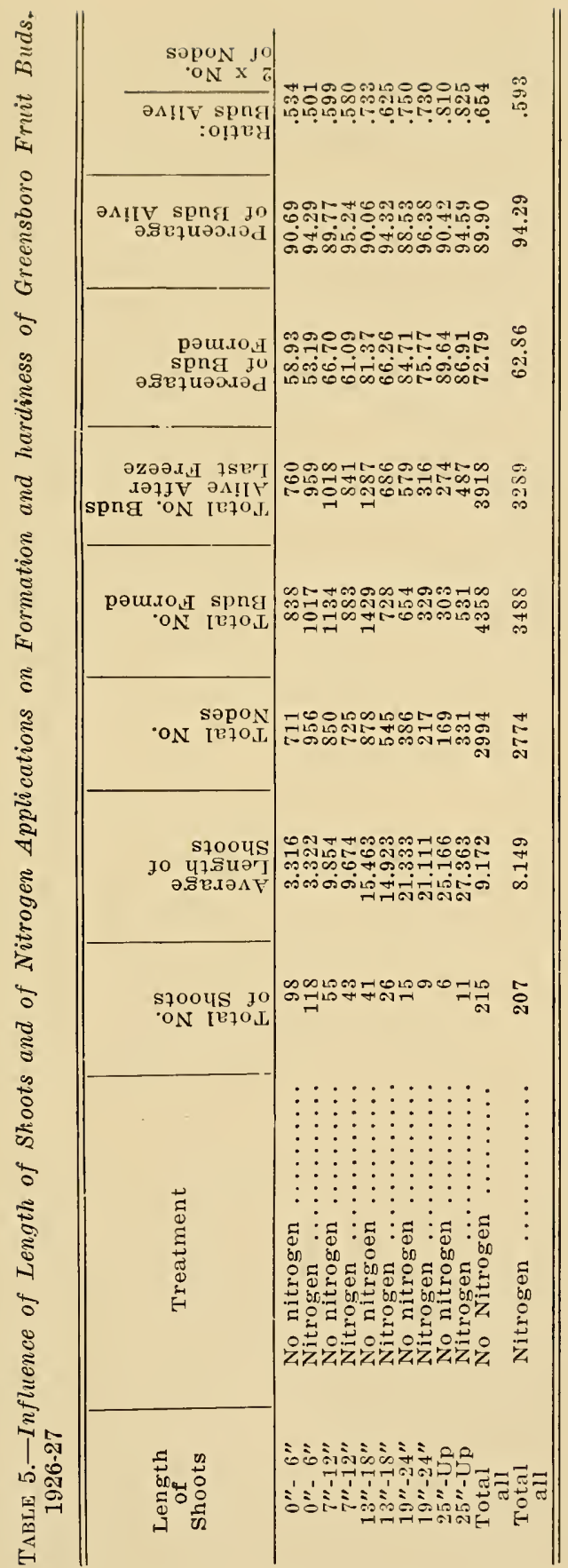


Little difference was indicated between the trees that received four or 16 pounds of nitrate of soda in the formation or hardiness of the fruit buds. The large amount of nitrate applied probably caused some root injury so that the nitrogen was not absorbed. This view is supported by the data for the total nitrogen and moisture content of the fruit buds, which will be considered later.

The response of the Salwey to pruning and applications of nitrogen was quite different from that of the Greensboro (Table 3 ). The check trees produced the hardiest buds, and when nitrogen was applied to similar trees there was an indication that the hardiness was slighty decreased. The buds of the trees that had been summer pruned were significantly more tender than those of the checks, and when nitrogen was applied to similar trees the buds were still less resistant. This is in agreement with the results for the Greensboro for the previous winter. The conditions that increased or prolonged the growth of the trees resulted in less hardy buds.

From the data presented it would seem that the conditions which promoted the growth of the trees either by a more rapid rate of growth or by a longer growing period caused the fruit buds to be susceptible to winter injury. The apparent exception of the Greensboro during the winter of 1926-27, following a crop, indicates that the production of fruit is an important factor in determining the hardiness of the buds.

\section{Relation of Length of Shoot to the Formation and Hardiness of Fruit Buds}

It may be deduced theoretically that the formation and the hardiness of the fruit buds should decrease with increasing length of the shoot on which they are borne. Casual field observations indicated this to be true. Accordingly studies were made as regards the number of fruit buds formed per node and the hardiness of these buds as affected by the conditions influencing the length of the shoot. For these studies the shoots were divided into the following classes: 0 to 6,7 to 12,13 to 18,19 to 24 , and 25 to 36 inches.

\section{Fruit Bud Formation}

The data for the winter of 1925-26 for Greensboro show that the short shoots, 0 to 6 inches, formed the smallest percentage of fruit buds, and the longest shoots, 25 to 36 inches, the highest (Table 4). There was little, if any, difference in the percentage of buds formed on shoots of the same length from trees that received nitrate of soda and from those that did not. The interesting fact brought out by the data is that in the case of the Greensboro, fruitbud formation increased as the length of the shoots became longer, while the behavior of the Salwey, as will be shown later, was the opposite in this respect.

The percentage of fruit-bud formation on the Greensboro during the season of 1926-27 was again related to the length of the shoots on which they were borne (Table 5). When the node is taken as the 


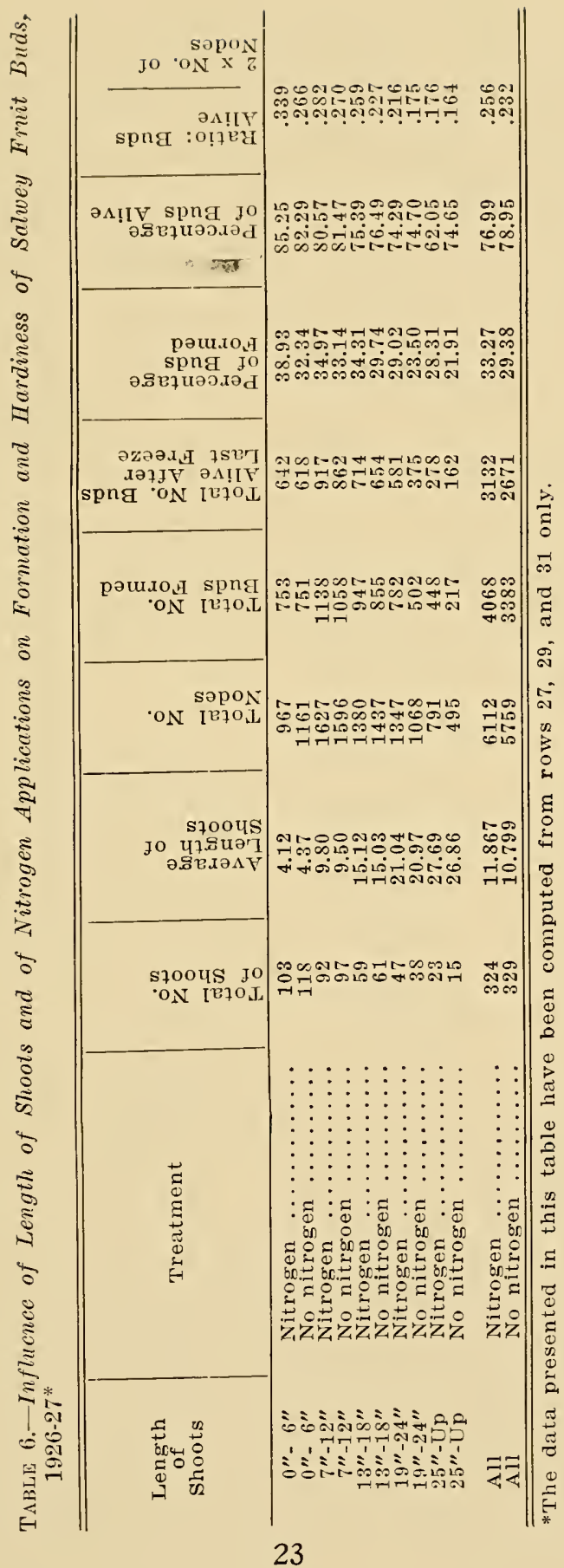


unit of comparison the short shoots formed the least and the longest shoots the most buds. Applications of nitrogen to the trees had a tendency to reduce the percentage of buds formed. In this connection it is well to point out that with a variety like Greensboro, the effect of nitrogen applications on the potential fruit-bearing of the trees is through its influence on the length of the shoots rather than by greater fruit-bud formation. This is true because the production of a large number of long shoots increases not only the bearing area of the trees but also the number of buds formed at each node.

TABLE 7.-Coefficients of Correlation Between Length of Shoot and Formation and Burdiness of Greensboro Fruit Buds, 1925-26

\begin{tabular}{lrl}
\hline \hline Characters Correlated & \multicolumn{2}{c}{$\begin{array}{c}\text { Coefficients of Correlation } \\
\text { No Nitrogen }\end{array}$} \\
\hline $\begin{array}{l}\text { Percentage of buds formed with length of shoot...... } \\
\text { Percentage of buds alive with length of shoot } \ldots \ldots \ldots\end{array}$ \\
\hline \hline
\end{tabular}

The short shoots of the Salwey formed the highest percentage of buds, and as the length of the shoots increased the percentage of fruit-bud formation became smaller (Table 6). "This is the opposite of what was found to be true of the Greensboro, and shows a marked difference in these relationships between shoots of the same length of the two varieties under study.

\section{Hardiness of the Buds}

The buds on the short shoots of the Greensboro were significantly more resistant to freezing temperatures during the winter of 192526 than those borne on the long shoots (Table 5). Hardiness varier inversely with the length of the shoots on which the buds were borne. The effect of nitrogen applications was to reduce the hardiness of the buds on shoots of the same length. This was particularly true for buds of the short shoots but in the case of the long ones there was little difference in their resistance.

The data for the Greensboro for the winter of 1926-27 show no difference in the hardiness of the buds borne on long or short shoots (Table 6). The shoots of all lengths on trees that had been fertilized with nitrate of soda had a higher percentage of buds which survived the winter than similar classes of shoots from trees not fertilized. This circumstance may have been due to a iarger crop of fruit borne per unit of bearing area on the trees not fertilized as compared to the ones that had received nitrogen.

The fruit buds borne on the short shoots of the Salwey were hardier than those on the long ones. From the data in Table 6 there is an indication that the tenderness of the buds was proportional to the length of the shoot on which they were borne. Nitrogen applicatinns had little, if any, effect on the hardiness of the buds, as the differences in resistance of the buds borne on shoots of the same length, with or without nitrogen, are within the limits of experimental error.

These relations for the Greensboro during the winter of 192526 are more clearly brought out by Table 7 , in which are given the 
coefficients of correlation for the fruit-bud formation and hardiness of the buds as correlated with the length of the shoots on which they were produced. The percentage of fruit-bud formation was highly correlated with the length of the shoot on which the buds were borne; the coefficient of correlation without nitrogen was $+.808 \pm .047$, and with nitrogen applications, $+.784 \pm .052$. Hardiness of the buds was negatively correlated with the length of the shoots, the coefficients of correlation being $-.6+5 \pm .079$ and $-.319 \pm .121$, without and with nitrogen, respectively. The data given above and that to be presented later for the Salwey show that both fruit-bud formation and hardiness were negatively correlated with the length of the shoot.

\section{Dry Weight of the Fruit Buds}

Several investigations have shown that hardiness is related to a low water content of the tissue. From this and other considerations it was thought that pruning or nitrate of soda applications through stimulation of the growth of the trees would increase the water content of the buds and thus decrease their resistance to injury from freezing temperatures. To study the relations existing between the dry weight of the buds to the growth conditions under which the buds were formed, as well as the relation of their moisture content to their hardiness, the percentage of dry weight of the buds was determined at intervals throughout the winter: by methods already described.

TABLE 9.-Percentage of Dry Weight of Fruit Buds, 1926-27

\begin{tabular}{|c|c|c|c|c|c|}
\hline & & & Percentage & of Dry & Weight on \\
\hline & Row & Treatment & Nov. 15 & Dec. 17 & Jan. 28 \\
\hline ¿̊ & 31 & Check & 49.930 & 51.743 & 49.244 \\
\hline है & 31 & 4 pounds of nitrate of soda ... & 50.526 & 51.239 & 48.752 \\
\hline ¿ّ & 29 & No nitrogen $\ldots \ldots \ldots \ldots \ldots \ldots \ldots$ & 50.657 & 50.434 & 47.826 \\
\hline 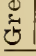 & 29 & 16 pounds of nitrate of soda .... & 51.068 & 50.070 & 48.361 \\
\hline is & 31 & 4 pounds of nitrate of soda ..... & 45.839 & 46.220 & 44.174 \\
\hline 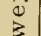 & 31 & Check $\quad \ldots \ldots \ldots \ldots \ldots \ldots \ldots$ & 46.332 & 46.577 & 45.199 \\
\hline$\underbrace{\circ}_{\pi}$ & 27 & Two summer prunings $+\ldots \ldots$ & 44.797 & 45.220 & 43.944 \\
\hline & 27 & $\begin{array}{l}4 \text { pounds of nitrate of soda } \\
\text { Two summer prunings ....... }\end{array}$ & 44.894 & 45.226 & 44.753 \\
\hline
\end{tabular}

Samples were taken three times during the winter of 1925-26 for dry weight determinations (See Table 8). The check trees had the highest percentage of dry weight on November 20 and retained this position throughout the winter. The summer-pruned trees had the lowest percentage of dry weight. For several days previous to December 17 , the time of collecting the second lot of samples, the weather had been cold with the maximum temperatures ranging from $21^{\circ}$ to $37^{\circ} \mathrm{F}$. Samples taken at this time were lower in inoisture than earlier. The buds with the lowest percentage of dry weight on November 20 made the greatest gain in dry matter, while the check or similar trees which had been fertilized and which had the highest 
percentage of dry weight on the earlier date, lost the least water during the cold period.

The samples collected on January 19 were taken during another warm period. At this time the buds had increased in moisture so that their percentage of dry weight was approximately six percent less than that on December 17. The buds with the highest percentage of dry weight earlier in the season still maintained their relative position, and those from the summer-pruned trees which had the lowest dry weight still contained the most water. Nitrogen applications did not have any marked effect on the percentage of dry weights of the buds.

The differences in the percentage of dry weight of the buds from the various treatments of the Greensboro or Salwey were small during the winter of 1926-27 (Table 9). These small differences, not significant in some instances, indicate that the practices which promoted the growth of the trees during the previous growing season reduced the percentage of dry weight of the buds. There was a very significant difference between the buds of the two varieties in the percentage of dry weight as it was much higher throughout the winter in the hardy Greensboro than in the tender Salwey.

It would seem that the practices which accelerated the growth of the trees, or reduced the leaf area, or both, decreased the percentage of dry weight of the fruit buds of both varieties. These and other data to be presented show a fairly close relation between percentage of dry weight and hardiness of the buds.

\section{Bound Water of the Fruit Buds}

During the winter of 1925-26 the moisture content of the Greensboro fruit buds was found to be related to the vegetative vigor of the trees. In view of this relation it was thought that perhaps more of the water of the hardy buds was held tenaciously during freczing weather and was not given up to form ice so readily as with the more tender buds. This relation was studied during the winter of 1926-27, and the data are given in Table 10.

The Salwey fruit buds had not only a lower percentage of dry weight than those of the Greensboro (Table 9), but also a smaller percentage of water held tenaciously (Table 10). There was a smaller difference between the various treatments of the Greensboro in the amount of bound water than in those of the Salwey. The applications of nitrogen to the Salwey trees decreased the percentage of bound water of the buds, in some way, presumably through prolonged growth and carbohydrate utilization. Summer pruning apparently had little or no effect on the bound water of the buds.

It is not possible to draw conclusions regarding the relation of the water held tenaciously by the buds and their hardiness, on account of the small differences between treatments. There is some indication that the hardy buds contained more water which was less easily given up than from the tender buds. 


\section{Size and Increase in the Dry Weight of the Fruit Buds}

Since each bud is a unit, composed of the floral parts enclosed in a number of bud scales, the dry weight of 100 buds has been calculated for the samples taken at the different times during the winter. This was done to study: (a) the relation of the vegetative growth of the trees to the size or weight of the buds; (b) the relation of the growth of the trees to that of the buds as measured by their increase in dry weight during the winter months. These data for the winter of 1925-26 are given in Table 11. There is an indication that the treatments which promoted the growth of the trees caused the buds to be smaller at the time the first samples were taken than those not forced to grow so late. The check trees had the largest buds on November 20, and remained so to January 19 . The heavy dormant pruning, summer-pruning, or nitrate of soda applications had reduced the size of the buds at the time the first samples were taken.

There was an appreciable increase in the dry weight of the buds from November 20 to January 19 (Table 11). The buds from the trees that had received the application of nitrate of soda made the greatest growth with the exception of the trees that had been pruned two or three times during the preceding summer. In the latter case the fruit buds from the trees not fertilized made the greatest growth. The summer-pruning reduced considerably the leaf area and at the same time stimulated the growth of the trees. Applications of nitrogen to these trees caused increased vegetative growth, and apparently the carbohydrates had been utilized during the summer and fall at the expense of the fruit buds.

In the fall of 1926 the Greensboro fruit buds borne on the trees fertilized with nitrate of soda were larger on November 15 than those from similar trees not fertilized (Table 12). By January 28, 1927, the fruit buds of the latter had grown until they were practically as large as those of the former, with the exception of the buds of the trees of Row 29. In this case apparently there has been cross feeding of the root systems of the trees not fertilized and probably root injury to those that received the 16 pounds of nitrate of soda, as is indicated by the moisture and nitrogen content of the buds. The results with the Greensboro are different from those of the previous winter in that the trees fertilized with nitrate of soda had the smallest buds at the beginning of winter and these grew more rapidly than those of the trees not fertilized.

The probable explanation for this difference in the growth of the buds is that the crop of fruit produced in the summer of 1926 altered the nutritional conditions so that the nitrogen trees with the larger leaf area were able to produce the crop and at the same time store more carbohydrates than those not fertilized. This difference in the growth of the buds during the winter apparently accounts for the greater hardiness of those borne on the trees that had been fertilized. 

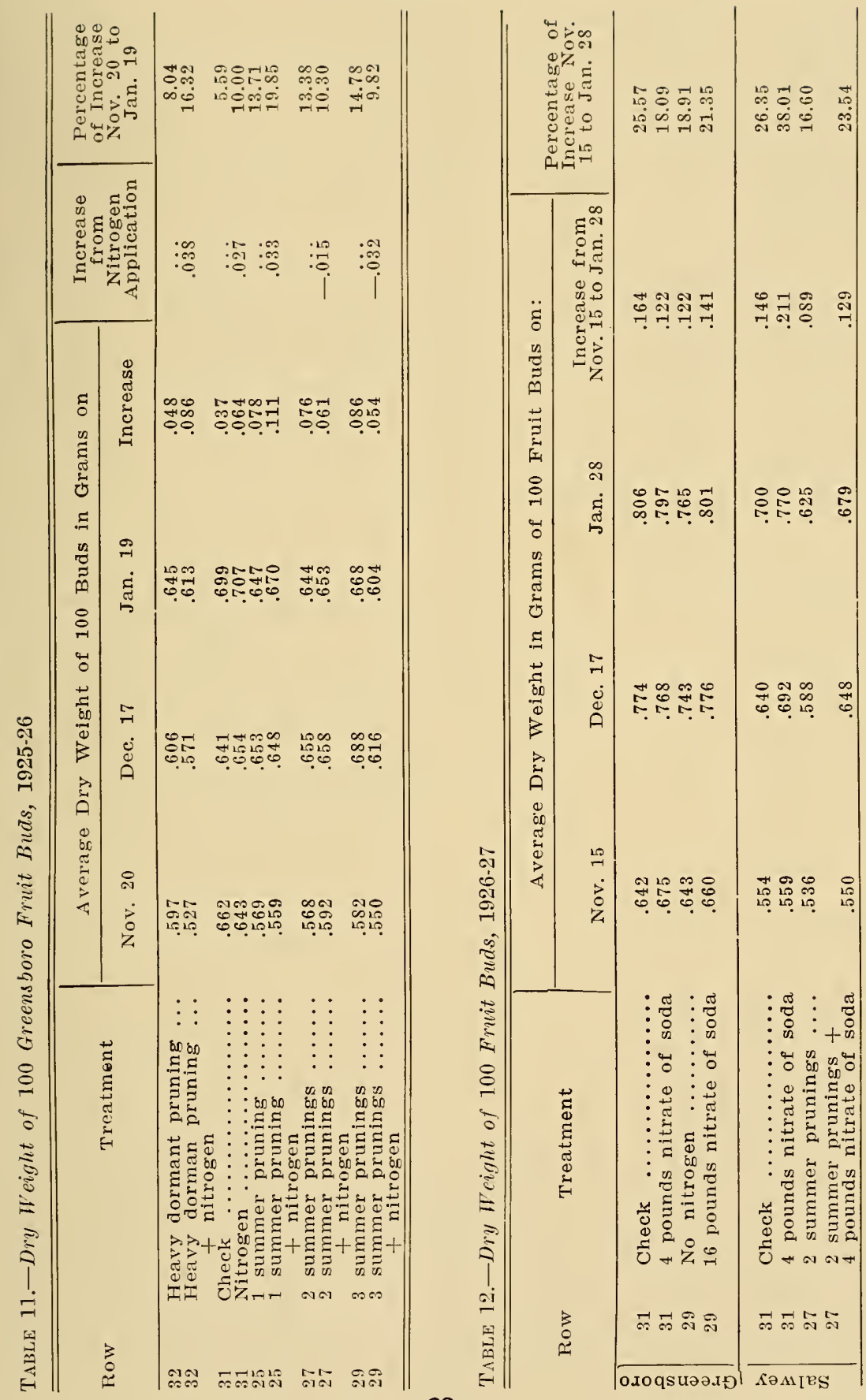
There was little difference in the size of the Salwey buds from the trees of the various treatments on November 15 (Table 12). It would seem that the two summer prunings reduced the size of the buds and retarded their growth during the winter. Nitrogen applications caused the buds to be larger and increased the amount of growth they made from November 15 to January 28 . The buds of the Salwey were considerably smaller than those of similar Greensboro trees.

It appears that the practices, pruning or nitrate applications, which stimulated the growth of the trees or prevented the accumulation of food materials, through growth or production of fruit, reduced the weight of the buds at the approach of winter. There is a strong indication that the buds on the more vegetative trees which made greater gains in dry weight during the winter months than the buds on the less vegetative trees were due, in part, to the relatively high water content of the vigorous buds. The data presented show that there was a negative correlation between the increase in dry weight of the buds and their hardiness.

\section{Percentage of Total Nitrogen in the Fruit Buds}

In some earlier work (20) on the influence of nitrate of soda on peach trees it was shown that application of nitrate decreases the hardiness of the fruit buds. It was also shown that there are residual effects from the nitrogen the following year. These results give weight to the idea that buds high in nitrogen are susceptible to injury from freezing temperatures. To study the effect of pruning and nitrate of soda applications on the nitrogen content of the buds and the relation of the latter to hardiness, total nitrogen determinations were made of the buds from the various treatments during the winters of 1925-26 and 1926-27. These data are given in Tables 13 and 14.

In general, the buds that were high in percentage of dry weight were low in percentage of total nitrogen, while those low in dry weight were high in total nitrogen. In other words, there seems to be a close relation between the moisture and nitrogen content of the buds. The data for the total nitrogen content of the buds at intervals through the winter of 1925-26, expressed in percentage of the dry weight of the fruit buds, are given in Table 13. These data show that during the winter there is a steady increase in the percentage of total nitrogen of the buds, as it was the lowest in November and the highest in January.

Pruning was a more important factor in determining the nitrogen content of the buds than was the application of nitrate of soda. The check trees had the lowest percentage of nitrogen in the buds at the time the first samples were taken and retained this position through the winter. The trees which were pruned heavily in the dormant season or which were summer-pruned had a high percentage of total nitrogen content of the buds. However, the buds from the trees which had been summer-pruned two or three times and had been fertilized were little different from those of similar trees not fertilized. A con- 


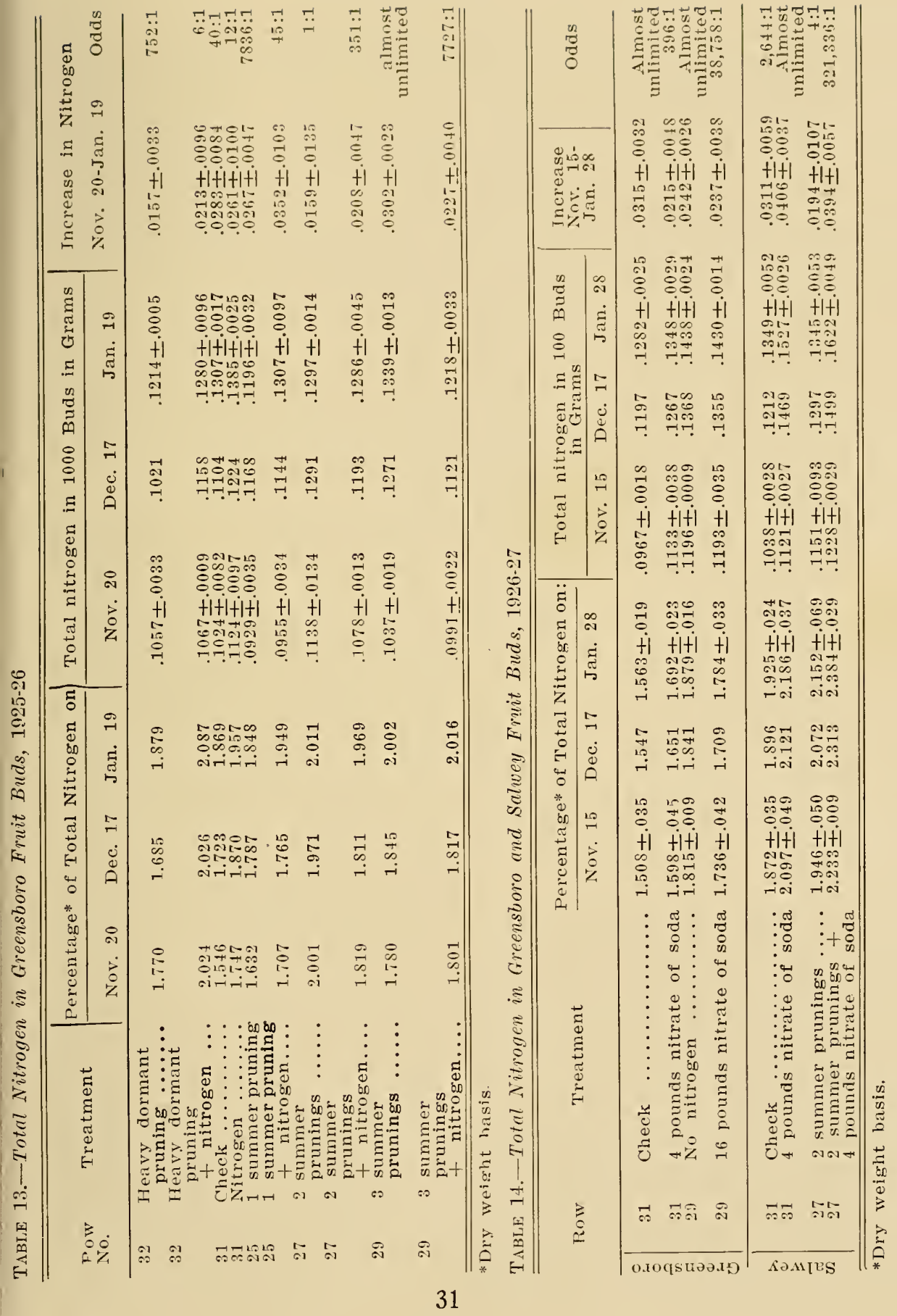


siderable part of the nitrogen that was available to the fertilized trees probably had been used up in the growth of the trees, so that at the beginning of dormancy less of this material was stored than in the case of the trees not fertilized.

During the winter 1926-27 it was again found that applications of nitrate of soda made at the beginning of the previous growing season increased the percentage of total nitrogen in the buds as compared to similar ones not fertilized. The data of Table 14 would suggest that the unfertilized trees of Row 29 had been cross-feeding in the fertilized areas, as the buds of these trees had a higher nitrogen content than those from the fertilized trees.

TABLE 15.-Coeffieients of Correlation Between Moisture, Total Nitrogen, and IIardiness of Greensboro Fruit Buds, 1925-26

Characters Correlated

Coefficients of Correlation

Total moisture of the buds with their total nitrogen content . . . $+.408 \pm .106$ Increase in dry weight of the buds from Nov. 20 to Jan. 19 with the percentage of total nitrogen ............. $+.616 \pm .079$

Increase in dry weight of the buds from Nov. 20 to Jan. 19

with the percentage of total moisture ................386 .108

Increase in dry weight of the buds from Nov. 20 to Jan. 19

with the precentage of buds alive ...............

Percentage of buds alive with their total moisture content ......

Percentage of buds alive with their total nitrogen content ...... -

Summer-pruning increased the percentage of total nitrogen in the buds of the Salwey. The buds of these trees were the highest in nitrogen at the beginning of dormancy and remained so throughout the winter. The buds of both varieties increased in total nitrogen during the winter, as they were lowest in nitrogen in the fall and the percentage became greater as the winter advanced. The fruit buds of the Salwey contained a significantly larger percentage of total nitrogen than those of the Greensboro. The buds of the Salwey contained about three percent more water than those of the Greensboro, and in total nitrogen there is still a greater difference between the varieties.

To show more clearly the relations existing between moisture, nitrogen, increase in dry weight, and hardiness of the buds of Greensboro, coefficients of correlation have been calculated and are given in Table 15 for the winter of 1925-26. The moisture content of the buds was positively correlated with the percentage of total nitrogen. Likewise, the growth of the buds as measured by the increase in dry weight was significantly and positively correlated with their total nitrogen and moisture content. The percentage of buds that came through the winter uninjured was found to be negatively correlated with their gain in dry weight, with the total nitrogen content, and with the total moisture content of the buds. The coefficients of correlation are $-.511 \pm .094,-.679 \pm .068$, and $-.864 \pm .032$, respectively. The data for the Salwey indicated that these relations also hold for this variety. The wide differences in dry weight and total nitrogen between the Greensboro and Salwey are closely related to the hardiness of the buds of these two varieties. 


\section{Total Nitrogen in One Thousand Fruit Buds}

It has been demonstrated that nitrates influence the growth and hardiness of peach buds and theoretically there are good reasons for expecting such results. Since few data are available on this aspect of the problem the actual nitrogen content of the buds was determined. Furthermore, the gain in total nitrogen of the buds during the winter months would be a measure of their growth or of the movement of nitrogen into them. For these reasons the total nitrogen contained in 1,000 fruit buds has been calculated, and the data are given in Tables 13 and 14. There is an indication that during the winter of 1925-26 the buds from the trees not fertilized with nitrate contained less total nitrogen, although they were larger in size, than the ones from the fertilized trees (Table 13). All of the buds increased in total nitrogen from November 20 to January 19. The buds from the unfertilized trees made the most significant increase in total nitrogen cluring this period, excepting those from the trees which had been summer-pruned two or three times.

The increase in total nitrogen in the fruit buds was much more significant for the winter of 1926-27 than for the previous one (Table 14). These data show that the treatments which promoted the growth of the trees increased the amounts of total nitrogen in the buds. The buds from the checks or from trees that had not been fertilized were lower in total nitrogen from November 15 to January 28 than those from similar trees which had received nitrate of soda. During this period there was a very significant increase in the amounts of total nitrogen in the buds of the trees of all treatments, excepting one, which was probably due to error. The buds from the Greensboro trees not fertilized made the most significant increase in total nitrogen, while the opposite was true of similar trees of the Salwey.

It seems that the increase in total nitrogen was associated with the growth of the fruit buds, as the gain in dry weight follows closely that of nitrogen. It should be pointed out that the Salwey buds, although of smaller weight, contained as much or more total nitrogen than those of the hardy Greensboro.

\section{Composition of the Fruit Buds}

The data presented have shown that hardiness is associated with a low water and total nitrogen content of the fruit buds. 'The growth of the buds as measured by the increase in dry weight and gain in total nitrogen was found to be related to the vegetative conditions of the trees. The practices that stimulate the growth of the trees influence not only the amounts of carbohydrates used in growth but also the quantities stored. In view of these facts and in the belief that there might be some relation between carbohydrate storage and the growth and hardiness of the buds, analyses were made of samples collected from trees under the various treatments, on January 28,1927 . These data are given in Table 16.

Summer-pruning or nitrogen applications had little effect on altering the composition of the fruit buds within the variety. It is 
expected that greater differences would have been found had analysis been made of the bark or wood on which the buds were borne, since these serve as storage tissues. The data of Table 16 show a wide difference between the buds of the two varieties, Greensboro and Salwey, in the percentage of reducing sugars, total sugar and starch, as well as moisture and total nitrogen. It seems reasonable to assume that the larger amounts of reducing and total sugars of the Salwey buds were associated with the greater growth response of this variety. The Salwey fruit buds contained approximately twice the percentage of starch as those of the Greensboro.

Applications of nitrate of soda or summer-pruning had no effect on the percentage of sugars or starch found in the buds. There was considerable difference between the two varieties in the percentage of alcohol-soluble non-sugars present, and the larger amounts were found in the buds of the hardy Greensboro. Applications of nitrate of soda seemed to have some effect on the percentage of alcoholsoiuble non-sugars, as a comparison between these materials and the percentage of total nitrogen shows that the buds with a low nitrogen content had a larger amount of the former present. It seems that nitrogen applications caused a greater reduction in the percentage of alcohol-soluble non-sugars in the buds of the Salwey than in those of the Greensboro.

It would seem that the reserve food materials of the Greensboro are largely in forms not readily available for growth. The Salwey buds contained the largest quantities of soluble food materials and the smallest amounts of alcohol-soluble non-sugars and made the greatest response, as will be shown later. The growth of the buds was, apparently, the result of the nutritional conditions-a high sugar, water, and total-nitrogen content.

\section{DISCUSSION}

Greensboro and Salwey have been shown to differ greatly in respect to the formation of fruit buds. With the former variety there was a high and positive correlation between the percentage of fruitbud formation and the length of the shoots on which they were borne, while with Salwey the opposite was true. It follows then that the practices that cause the production of long shoots increase fruitbud formation on the Greensboro and reduce it on the Salwey. When shoots of the same length are considered, dormant or summer-pruning had no effect on the formation of fruit buds on the Greensboro. Fertilization with nitrate of soda had effects similar to that of pruning, except in the year that a crop of fruit was borne, when the percentage of buds formed was reduced on the shoots of all lengths of this variety. Summer-pruning decreases and nitrogen applications increase fruit-bud formation on the shoots of all lengths of the Salwey.

Dormant or summer-pruning has been shown to reduce the resistance of peach buds to low temperatures. Applications of nitrate 


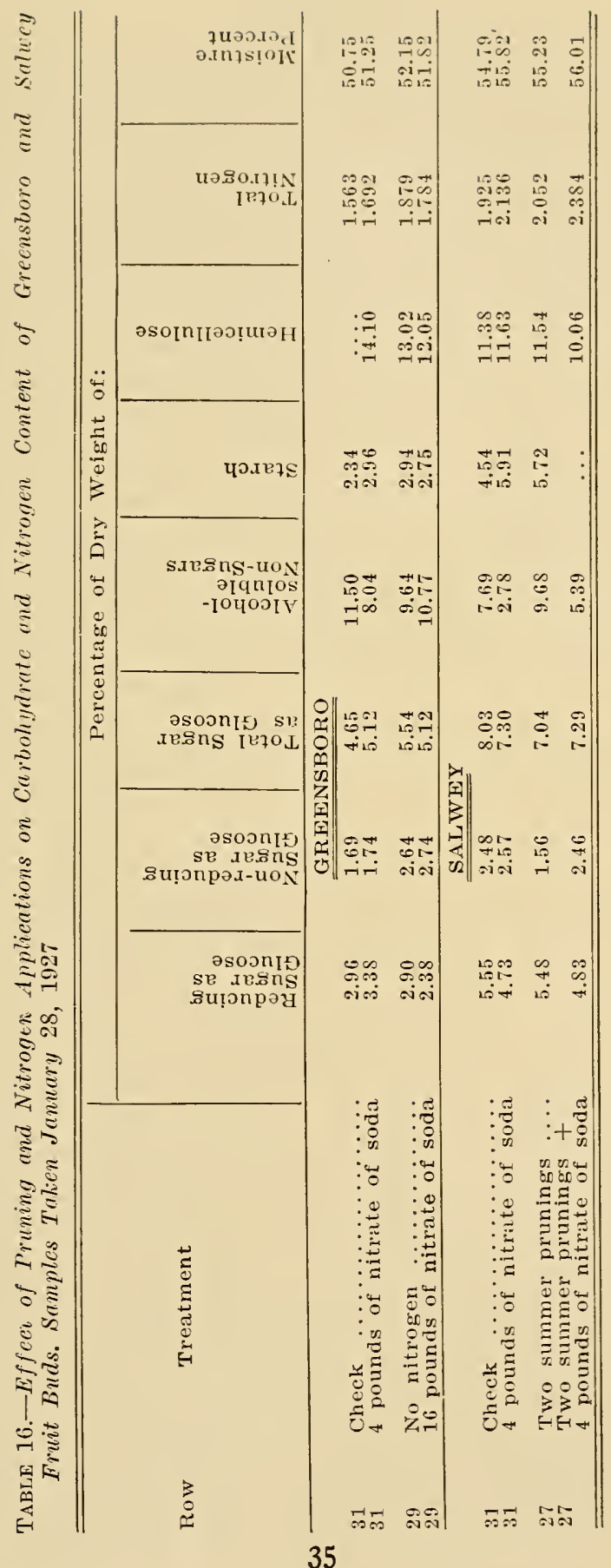


of soda had effects similar to that of pruning on the hardiness of the buds, except during the winter of 1926-27, when the buds on the nitrated Greensboro trees were more resistant than the unfertilized ones. This was due probably to the crop of fruit produced the previous summer. The writer (20) has reported that fertilization with nitrate of soda causes the fruit buds to be tender and that the degree of susceptibility to injury is in relation to the amounts applied. These horticultural practices stimulate tree growth in two ways: by increasing the rate of growth, and by prolonging the growing period. As a result of the more vegetative condition of the trees, longer shoots and more of them are produced. The buds borne on the long shoots are more tender than those of the short ones. A fairly high degree of negative correlation exists between the length of the shoots and the hardening of the buds of both varieties.

It has been observed by growers in years of severe winter injury to peach buds that the bulk of the crop is produced on the short shoots which resemble spurs, and the balance by the buds borne at the base of the longer shoots. Craig (19) has reported that in Canada some varieties of peaches may have their terminal shoots killed back each year, yet will produce fruit generally upon the spurs situated on the older wood. It follows that the more the trees are forced to grow, the more tender the buds will be because of the longer shoots if for no other reason. It seems permissible then to draw the conclusion that the conditions which cause some shoots to grow long and others to grow short have an effect on the hardiness of the buds.

The nutritional conditions that have been associated with growth are a high moisture and nitrogen content in proportion to the carbohydrates, or a narrow carbohydrate-nitrogen ratio. Pruning or nitrogen application increases the percentage of moisture and nitrogen contained in the buds. There is a fairly high degree of negative correlation which exists between hardiness and moisture and the nitrogen content of the buds.

The amount of injury to the buds would appear to be related to the growth made the previous growing season by the trees and this is associated with the water and nitrogen made available by pruning or nitrogen applications, or both. Not only is the production of wood by the trees increased by these practices, but also the growth of the buds as measured by their gain in total nitrogen and dry matter during the winter months. It has been shown that there is a significant positive correlation between the nitrogen or moisture content of the buds and their growth during the winter, and that the increase in the dry weight of the buds is negatively correlated with hardiness.

The buds of the Salwey have been found to contain a larger percentage of reducing sugars, total sugar, and starch than those of the Greensboro, while the buds of the Greensboro are high in alcohotsoluble non-sugars and hemicellulose. It appears that the food reserves of the Greensboro are less available for growth than are those of the Salwey, and this, in a measure, may account for the difference in growth and hardiness of the buds of the two varieties. 


\section{PAR'T II}

The Influence of Ringing and Nitrogen Applications on the Formation, Composition, Growth, and Hardiness of Fruit Buds

Ringing has been shown by many experiments to reduce growth and to increase fruit-bud formation. Chandler (16) has pointed out that the sap concentration of the roots of ringed peach trees was less than that of similar ones not girdled. The work of Curtis (24) and Harvey (44) showed that ringing reduced the nitrogen and caused an accumulation of carbohydrates above the ring. As the growth and nitrogen content are reduced by ringing and as carbohydrates acaccumulate, these conditions theoretically should result in increased fruit bud formation and hardiness.

The hardiness of the buds may be influenced in two ways: due to the accumulation of carbohydrates the sap concentration would be increased as shown by Chandler (16) and Curtis (24) and as a result there would be a greater quantity of complex carbohydrates and hydrophyllic colloids, causing greater retention of water against the drying forces of freezing than would be true of more vegetative tissue; (b) the accumulation of carbohydrates would perhaps increase the length of the rest period as suggested by Howard (52) and Abbott (1).

In order to study the effects of ringing on the formation, composition, growth, and hardiness of peach fruit buds the following treatments were used.

\section{Treatments}

In these experiments the main scaffold limbs were ringed by removing a strip of bark about one-fourth inch wide from around the limb. Care was taken to see that all of the phloem was removed at the time of ringing. After the bark was removed the wound was immediately covered with grafting wax. The previous and subsequent treatments of the trees used as well as the time of ringing may be summarized as follows:

Row 27. Greensboro: 1925, Light dormant and two summer prunings. 1926, Corrective pruning. 1927, Corrective pruning and all of the main limbs on each tree ringed on June 20.

Row 28. Greensboro: 1925, Heavy dormant pruning. 1926, Corrective pruning. 1927, Corrective pruning and one main limb on each tree ringed on June 20.

Row 29. Salwey: 1925, Light dormant and three summer prunings. 1926 and 1927, Corrective pruning and all limbs on each tree ringed on June 11, 1926, and June 21, 1927. 
Row 30. Salwey: 1925, Heavy dormant pruning. 1926 and 1927, Corrective pruning and half of all of the limbs on each tree ringed on June 11, 1926, and June 21, 1927.

Row 31. Greensboro and Salwey: 1925, Light dormant pruning. 1926 and 1927, no treatment. These trees were used as the checks.

The severity and type of pruning given was the same as that described in Part I. Each spring a standard 4-pound application of nitrate of soda was applied at the time of blooming to every other tree in all rows.

\section{EXPERIMENTAL RESULTS}

In these studies the effects of ringing and the application of nitrate of soda on the growth response of the trees has been observed. The influence of these practices on the dry weight, bound water, total nitrogen, and carbohydrate content of the buds has been determined. The changes in dry weight and total nitrogen content of the buds have been followed through one winter. The growth of the buds as measured by their increase in dry weight, gain in total nitrogen, gain in diameter of the naked buds and the development of the pollen during the winter months has been followed. These various phases of the problem will be considered in detail.

\section{Growth Response}

Within a short time, one to two weeks, after the limbs had been ringed, all terminal growth ceased, and terminal buds were formed. By the end of a month the leaves had taken on a yellow color which became leeper and finally, in late fall, changed to a deep reddishorange. The bark likewise changed color and in late fall the shoots of the ringed limbs were a bright to a deep red. This was particularly noticeable with the shoots of the Salwey which are normally a brownish-green color. The development of bright pigments in the leaves and bark indicates the accumulation of sugar and the formation of complex compounds of high molecular weight. Not only was the change in color evident but the shoots produced on the girdled limbs were much more stocky: i. e., they were larger in diameter in proportion to their length than those borne on similar limbs not ringed. Leaf fall took place on the girdled Salwey and the normal Greensboro trees at about the same time. The leaves on the ringed limbs were shed in advance of those of the normal trees of the same variety.

Marked differences were observed in the time of blooming ofthe trees in the various treatments in the spring of 1928. The check trees of the Salwey bloomed about two days earlier than similar ones of the Greensboro. Of the treatments under consideration the blossoms first to open were on the trees that had received only nitrate of 
soda; then in order of blooming were the checks and finally the trees that had been ringed.

The ringed trees bloomed about a week to ten days later than the check trees. The development of the flower and leaf buds was retarded in all cases by the ringing. At bloom the normal order of the opening of the flowers of both varieties was reversed: i. e., the buds at the base of the shoots on the ringed limbs opened first, and blooming proceeded toward the terminals. The check and fertilized trees of both varieties bloomed normally. No explanation for this reversal in the normal activities of the ringed trees can be given. The explanation will probably be found in a change in the normal distribution of water, nitrogen, and food materials to the buds on the different parts of the shoot.

\section{Formation and Hardiness of the Fruit Buds}

In Tables 17 and 18 are given the data for the formation and hardiness of the fruit buds as influenced by ringing and nitrate of soda applications. In both years the trees probably were ringed too late in the growing season for this practice to have much effect on the formation of fruit buds.

\section{Formation of Fruit Buds}

The data for the winter of 1926-27 show that nitrogen applications increased the percentage of fruit buds formed (Table 17). In some instances the increase in fruit-bud formation following the nitrogen applications was small but significant. In no case did ringing increase the formation of fruit buds over that of the checks. Perhaps the most striking results from the different treatments on the formation of fruit buds were those obtained when half of the limbs of the trees were ringed and the others left normal (Row 30). Nitrogen applications had no effect on the percentage of buds formed or the ringed halves of these trees; neither did it have any influence on the normal limbs of the same trees.

The percentage of fruit-bud formation on the normal limbs was greatly reduced when some of the limbs on the same trees were ringed. Girdling half of the limbs on a tree not only disturbed the nutritional conditions above the ring but affected the limbs not girdled, as fewer buds were formed, and these were more tender than those of the checks. These and other data to be presented later indicate that ringing half of the main limbs of a tree and leaving the others normal affects both sides of the tree.

There would seem to be little question but that ringing half of the branches of the trees prevented to some extent the upward movement of nitrogen, and as a result the limbs not girdled received that which normally would have been used throughout the entire tree tops. This increased nitrogen that was available to the limbs not ringed apparently produced nutritional conditions very similar to that caused by two summer prunings (Part I), which resulted in reduced fruit bud formation. In this case it would seem that there had been 


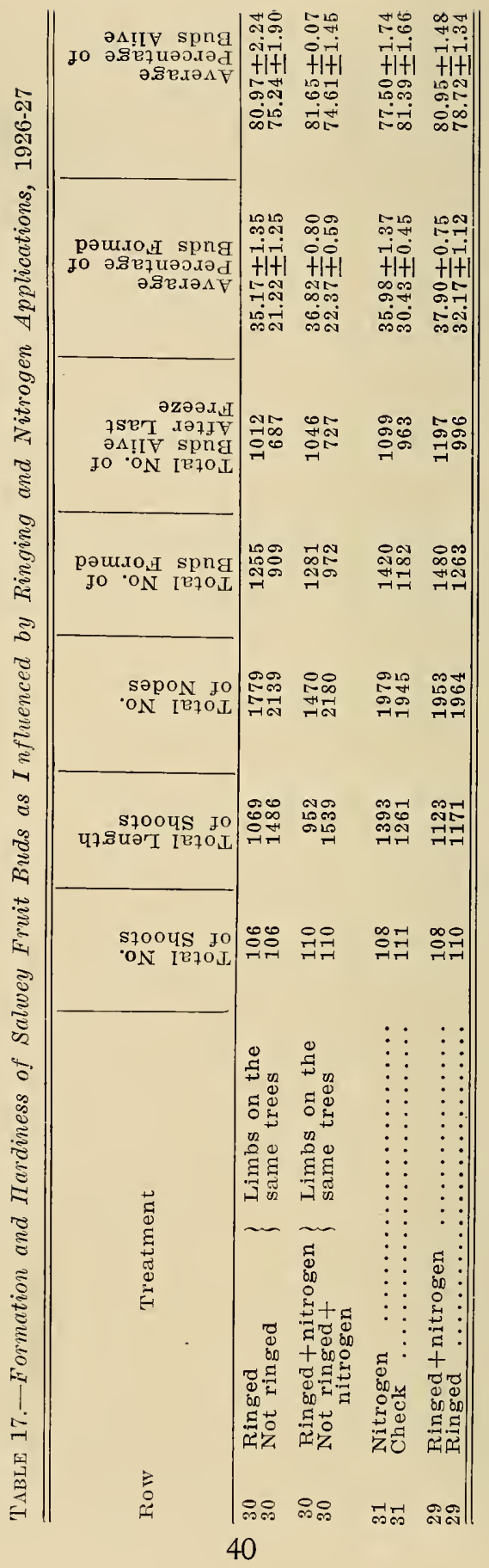




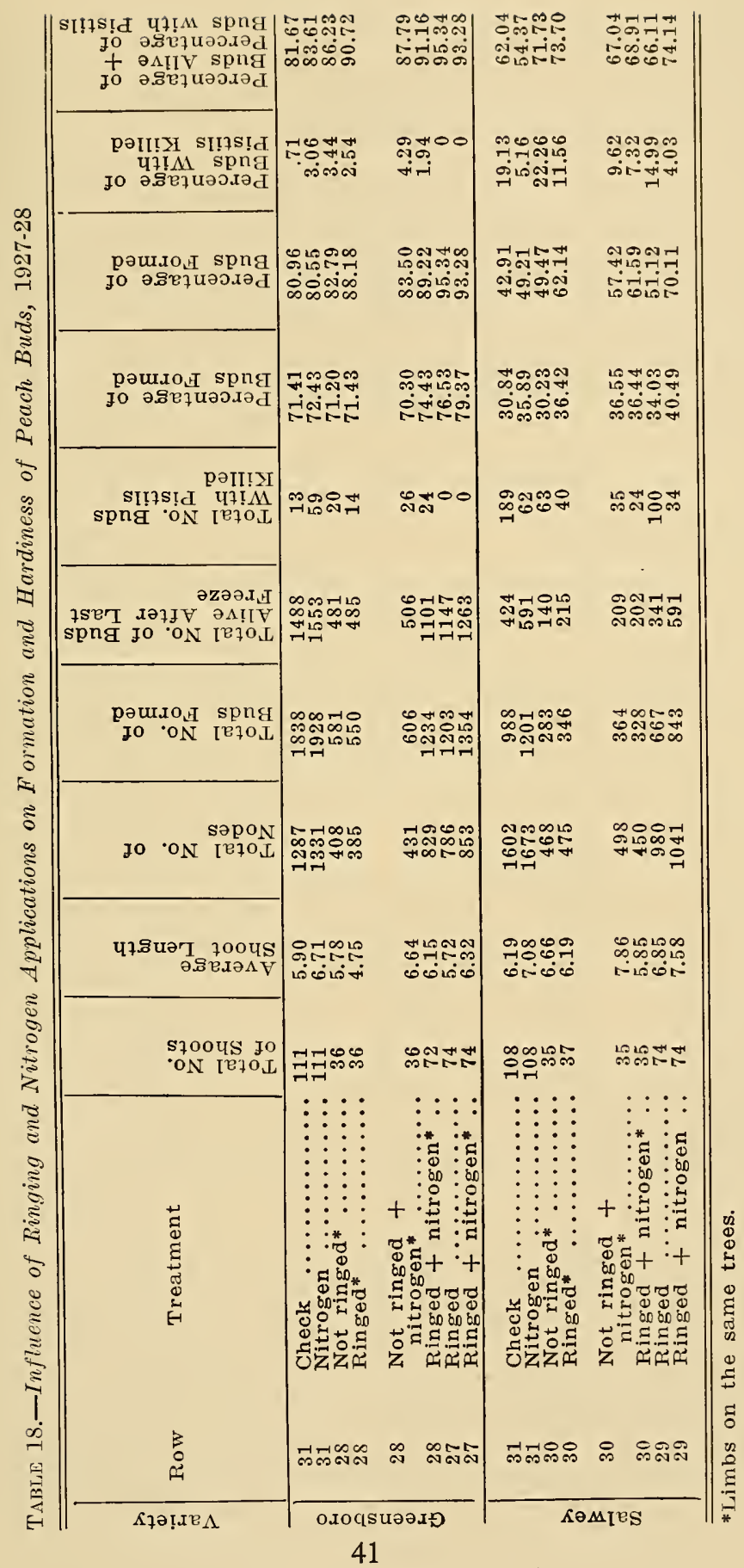


radial translocation of some of the nitrogen at least, and in this respect these results do not agree with those of Auchter (6), who found that nitrogen taken up by the roots on one side of the tree goes to the corresponding side of the tree top.

The results for the year 1927-28 were very little different from those of the previous one (Table 18). When all of the limbs on the trees were ringed, fruit-bud formation was slightly increased on both varieties. Ringing certain limbs on a tree had little or no effect on the formation of fruit buds on either the ringed or normal branches of either variety. Nitrogen applications likewise had little or no effect on fruit-bud formation. The slight effect of ringing on the formation of the fruit bud may be explained in one of two ways: either it had probably been initiated before the trees were ringed, or it was done too late to affect sufficiently the carbohydrate-nitrogen relations before fruit-bud initiation.

\section{Hardiness of the Buds}

The fruit buds borne on branches ringed during the previous June were no hardier during the winter of 1926-27 than were those of the checks, except when nitrogen was applied (Table 17). It has been pointed out previously that in the winter of 1927-28 a minimum temperature of $23^{\circ} \mathrm{F}$. on March 17 killed a rather large percentage of the pistils of the fruit buds of the Salwey and a few of the Greensboro. It is not known whether only pistils or, in some cases, the entire buds were killed at this time. The data are unusual and to the writer's knowledge no similar case has been reported.

The effect of the nitrogen applications made at the time of blooming in the spring of 1927 on the hardiness of the Salwey buds during the winter of 1927-28 is clear in so far as the fertilized trees had the largest percentage of live buds (Table 18). Ringing a part of the entire tree increased the percentage of buds of both varieties which came through the winter uninjured. The application of nitrogen to the girdled trees also resulted in still greater hardiness of the buds. Ringing all of the branches of a tree was more effective in increasing the hardiness of the buds than when only a part of the limbs were girdled. This difference probably was due to the low moisture and nitrogen content of the buds of the ringed limbs, as will be "shown later.

An examination of the data reveals that applications of nitrogen to the Salwey trees resulted in injury from cold to the pistils of the buds. It has been shown that fertilization with nitrogen or pruning increases the nitrogen content of the buds and that this is negatively correlated with hardiness. The lack of hardiness in the buds of high nitrogen content has been shown to be due to the growth of the buds as measured by the gain in dry weight and total nitrogen during the winter months. Then the explanation for the resistance of the buds which received nitrate of soda seems to be that they were ad- 


\section{Relation of Length of Shoot to the Formation and Hardiness of Fruit Buds}

In order to study certain relationships, the data of Row 30 have been separated into four groups according to treatment: ringed plus nitrogen, not ringed plus nitrogen, ringed and no nitrogen, and, not ringed and ro nitrogen. The data have been further divided into five classes, according to the length of the shoots. These data for the Salwey for the winter of 1926-27 are given in Table 19. Ringing half of the main limbs of the trees during June was found to increase the percentage of fruit buds formed on the shoots of all lengths as compared to the formation of buds on the same trees but on branches that had not been girdled.

TABLE 20.-Coefficients of Correlation for Formation and Hardiness of Fruit Buds as Correlated with Length of Shoot on Which the Buds were Borne, 1927-2S

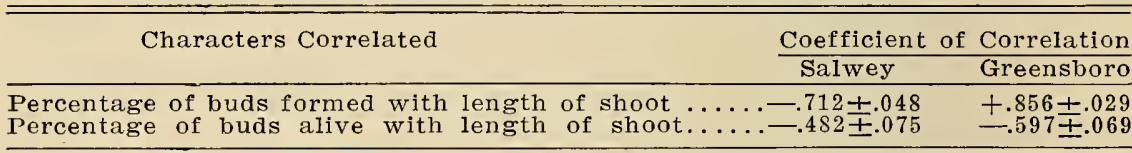

The striking relation brought out by the data of Table 19 is that ringing increased fruit-bud formation on the long shoots so that they formed approximately the same percentage of buds as did the short ones. The hardiness of the buds on shoots of the same length was not influenced by ringing or nitrate of soda applications. Hardiness was related to the length of the shoot on which the buds were borne, as the hardiness of the buds decreased as the length of the shoot increased.

Detailed data for the winter of $1927-28$ are not included for the reason that they are little different from that given in Part 1 . The trees were probably ringed too late in the summer of 1927 for the ringing to have any appreciable influence on the formation of fruit buds. Cciefficients of correlation have been calculated for the formation and hardiness of the buds with the length of the shoot on which they were produced, and these are given in Table 20 . In calculating the coefficients of correlation all of the data for the season, for each variety, have been included. Thus the data do not show the difference in truit-bud formation or hardiness of the buds due to treatment but simply the general behavior of the varieties. 'This has been done because it was thought unnecessary to distinguish between treatments, since the growth conditions that produced long shoots caused the buds to be tender.

The hardiness of the buds of both varieties was negatively correlated with the length of the shoots. The coefficients of correlation between the length of the shoots and the percentage of buds alive for the Salwey and Greensboro are: $-.482 \pm .075$ and $-.597 \pm .069$, respectively. The formation of fruit buds on the Salwey was negatively, and on the Greensboro positively, correlated with the length of the shoot. These coefficients are $-.712 \pm .048$ and $+.856 \pm .029$, respectively. 


\section{Dry Weight of the Fruit Buds}

It has been shown that the practices which increased the growth of the trees decreased the percentage of dry weight of the fruit buds (Part I). To study the effects of ringing and of nitrate of soda applications on the percentage of dry weight of the fruit buds, samples of buds from the various treatments were taken three times during the winter of 1926-27 and once in the winter of 1927-28. These data are given in Tables 21 and 22. Ringing slightly increased the percentage of dry weight of the Salwey buds during the winter of 192627 (Table 21). There is an indication that when half of the branches of a tree were ringed, the buds borne on the girdled limbs had a slightly higher percentage of dry weight than those on the normal ones. These differences are too small in some instances to be mathematically significant. Fertilization with nitrate of soda may have increased the percentage of moisture in the buds as is indicated in the data, but the differences are too small in most instances to be significant. This probably was due to the early healing of the ringing wounds, so that the normal food movements were reestablished before cessation of growth.

TABLE 21.-Influence of Ringing and Nitrogen dpplications on Percentage of Dry

Weight of Salwey Fruit Buds, 1926-27

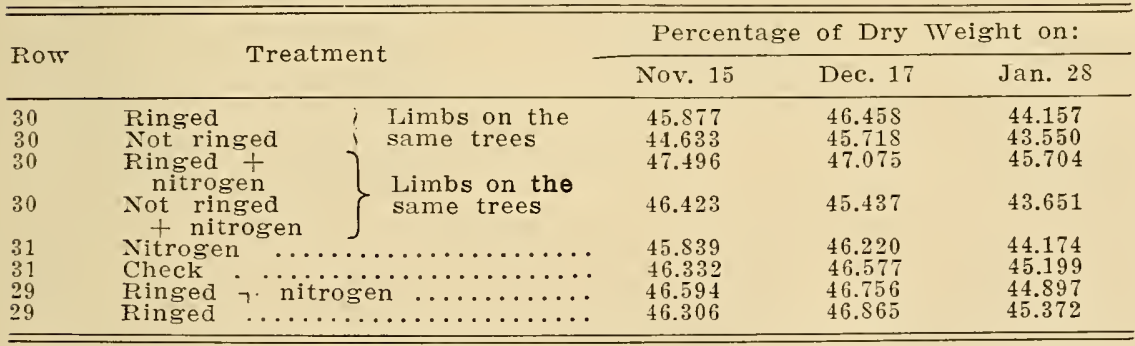

Rather wide differences in the percentage of dry weight of the buds existed on January 17, 1928 (Table 22). The percentage of dry weight of the buds was significantly increased by the ringing in all cases. Applications of nitrate of soda had very little effect on the percentage of dry weight of the buds regardless of whether they had been ringed or not. The large difference in the percentage of dry weight of the buds of the Salwey and Greensboro should be pointed out, since the buds of the Greensboro contained from five to eight percent less water than the Salwey. Not all of this difference was in the floral parts of the buds, and the data would be misleading without an explanation.

Examination of the buds of the two varieties showed that those of the Greensboro differed in character from those of the Salwey. The scales of the former variety were not only larger, but there were more around each bud than in the case of the Salwey. Although the fruit buds of the Greensboro as they existed on the shoots were 
larger in size and when removed weighed more than similar ones of the Salwey, yet when freed from scales they were considerably larger, as will be shown later. Since some of the scales were dead it is reasonable to assume that their water content was less than that of the floral organs. For this reason it would seem that the water content of the floral organs of the Greensboro buds was higher than the data indicate.

\section{Eound Water of the Fruit Buds}

The water held by the buds after drying for 144 hours at $30^{\circ} \mathrm{C}$. has been termed bound water. Ringing by causing an accumulation of carbohydrates would, perhaps, increase the colloids of the cells which would be able to retain water against drying forces. To study this relation, determinations of the bound water in the buds were made during the winters of 1926-27 and 1927-28. These data are given in Tables 23 and 24 . The treatments employed in these studies had very little effect on the percentage of bound water of the fruit buds, as the differences are small and not significant for either of the two years.

TABLE 22.-Influence of Ringing and Nitrogen Applications on Percentage of Dry Weight of Greensboro and Salwey Fruit Buds on January 17, 1928

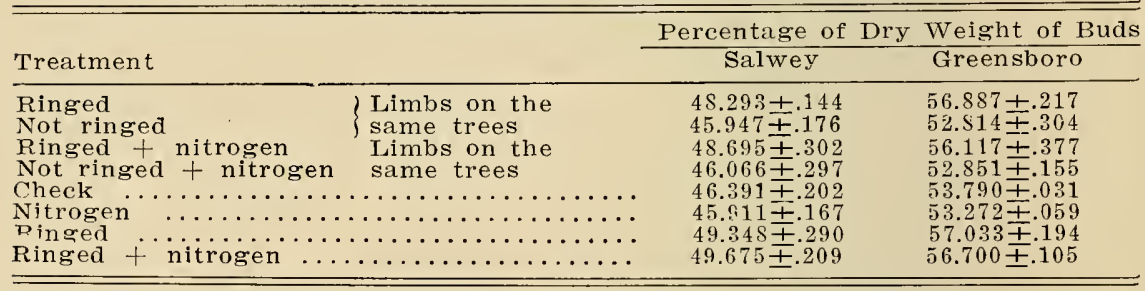

There is an indication that ringing increased and that applications of nitrate of soda decreased the percentage of bound water of the buds. The differences between the various treatments although small are consistent and indicate that the conditions that caused accumulation of carbohydrates increased the percentage of bound water and hardiness of the buds. In both seasons the buds collected late in the winter had in most instances a smaller percentage of bound water than earlier. This was especially true during the winter of 1927-28. The decrease in bound water from early to late winter probably was due to the growth and other metabolic processes of the buds.

\section{Size and Increase in Dry Weight of the Fruit Buds}

As a measure of the growth of the buds during the winter months of 1926-27, the dry weight of 100 buds was calculated. Data are given in Table 25. These data show that the buds produced on ringed limbs or trees were larger on November 15, 1926, than those borne on similar ones not girdled. Fertilization had practically no influence on the size of the buds. During the winter months the buds of the fertilized trees made the most and the ones on the girdled limbs the 


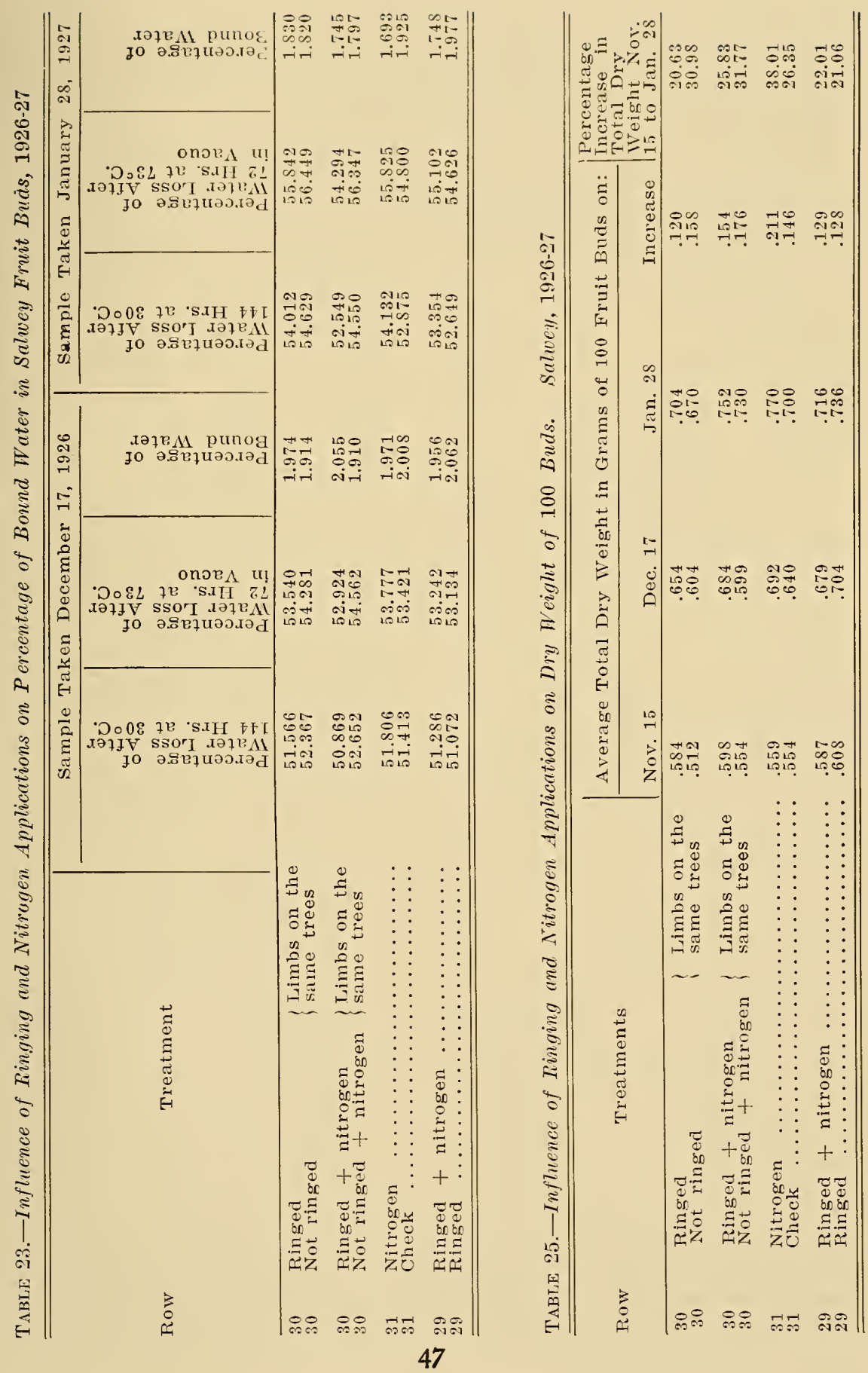


least increase in dry matter. It has been shown (Part I) that a high degree of negative correlation exists between the increase in dry weight of the buds during the winter and their susceptibility to winter injury. Data on the size and growth of the buds for the winter of 192728 will be considered later.

TABLE 24.-Influence of Ringing and Nitrogen Applications on Percentage of Bound Water in Peach Buds, 1927-28

Treatment

Percentare of Bound Water

\begin{tabular}{|c|c|c|c|c|c|}
\hline & & \\
\hline & & Jan. 17 & Feb. 28 & Jan. 17 & Feb. 28 \\
\hline Ringed & Limbs on the & 1.974 & $\ldots$. & 2.309 & \\
\hline Not ringed & same trees & 3.771 & $\ldots$ & 2.121 & $\ldots$ \\
\hline Ringed + nitrogen & Limbs on the & 1.932 & & 1.909 & $\cdots$ \\
\hline Not ringed + nitrogen & sarne trees & 1.768 & & 1.829 & \\
\hline Check $\ldots \ldots \ldots \ldots \ldots \ldots$ & $\ldots \ldots \ldots \ldots$ & 1.771 & 1.580 & 2.011 & $1 . \dot{6} \dot{58}$ \\
\hline Nitrogen $\quad \ldots \ldots \ldots \ldots$ & ( & 1.823 & 1.421 & 1.769 & 1.528 \\
\hline Ringed $\quad \ldots \ldots \ldots \ldots$ & - & 2.067 & 1.552 & 1.948 & 1.684 \\
\hline Ringed + nitrogen ... & & 1.904 & 1.408 & 1.847 & 1.579 \\
\hline
\end{tabular}

\section{Percentage of Total Nitrogen in the Fruit Buds}

The work of Curtis (24) and Harvey (44) showed that ringing reduces the percentage of nitrogen in the tissue above the ring. To study this relation in peach fruit buds the total nitrogen in samples of buds from the various treatments was determined three times during the winter of 1926-27, and twice in the winter of 1927-28. These data are given in Tables 26 and 27. Fruit buds produced on the trees that had received nitrate of soda contained a higher percentage of total nitrogen during the winter of $1926-27$ than did those from similar ones not fertilized (Table 26). Ringing half of the main limbs of a tree reduced the percentage of total nitrogen in the buds above the rings. When all of the branches on a tree were ringed, fertilization increased the percentage of nitrogen in the buds.

TABLE 26.-Influence of Ringing and Nitrogen Applications on Pcrcentage of Total

Nitrogen of Salwey Fruit Buds. Dry Weight Basis, 1926-27

\begin{tabular}{|c|c|c|c|c|c|}
\hline \multirow{2}{*}{ Row } & \multirow{2}{*}{ Treatment } & & \multicolumn{3}{|c|}{$\begin{array}{c}\text { Percentage of Total Nitrogen in } \\
\text { Fruit Buds on: }\end{array}$} \\
\hline & & & Nov. 15 & Dec. 17 & Jan. 28 \\
\hline $\begin{array}{l}30 \\
30\end{array}$ & $\begin{array}{l}\text { Ringed } \\
\text { Not ringed }\end{array}$ & $\left\{\begin{array}{l}\text { Limbs on the } \\
\text { same trees }\end{array}\right.$ & $\begin{array}{l}1.890 \pm .063 \\
2.072 \pm .039\end{array}$ & $\begin{array}{l}1.930 \\
2.002\end{array}$ & $\begin{array}{l}1.983 \pm .044 \\
2.097 \pm .035\end{array}$ \\
\hline $\begin{array}{l}20 \\
30\end{array}$ & $\begin{array}{l}\text { Ringed }+ \text { nitrogen } \\
\text { Not ringed }+ \text { nitrogen }\end{array}$ & $\begin{array}{l}\text { Limbs on the } \\
\text { same trees }\end{array}$ & $\begin{array}{l}1.926 \pm .063 \\
2.193 \pm .019\end{array}$ & $\begin{array}{l}1.999 \\
2.233\end{array}$ & $\begin{array}{l}2.066 \pm .082 \\
2.227 \pm .061\end{array}$ \\
\hline $\begin{array}{l}31 \\
31\end{array}$ & $\begin{array}{l}\text { Nitrogen } \\
\text { Check }\end{array}$ & & $\begin{array}{l}2.097+.049 \\
1.872 \pm .035\end{array}$ & $\begin{array}{l}2.121 \\
1.896\end{array}$ & $\begin{array}{l}2.136 \pm .037 \\
1.925 \pm .024\end{array}$ \\
\hline $\begin{array}{l}29 \\
29\end{array}$ & $\begin{array}{l}\text { Ringed }+ \text { nitrogen } \\
\text { Ringed } \quad \ldots \ldots \ldots\end{array}$ & 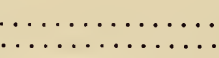 & $\begin{array}{l}2.119 \pm .067 \\
1.899 \pm .037\end{array}$ & $\begin{array}{l}2.164 \\
1.905\end{array}$ & $\begin{array}{l}2.237 \pm .046 \\
2.009 \pm .027\end{array}$ \\
\hline
\end{tabular}

In no case was there a reduction in the percentage of total nitrogen in the buds when all of the limbs were ringed as compared to those of the check trees. Apparently the ringing wounds had healed and sufficient time had elapsed for equilibrium between the nitrogen content of the root and top to have been reestablished. There is 
some indication that the percentage of total nitrogen was slightly greater on Jannary 28, 1927, than on November 15, 1926. Although the clifferences are small and not significant, they are all in that direction.

TabLE 27.-Infuence of Ringing and Nitrogen Applieations on Total Nitrogen Content of Peach Fruit Buels, 1927-2S

\begin{tabular}{|c|c|c|c|c|c|c|}
\hline \multirow{3}{*}{\multicolumn{2}{|c|}{ 'reatment }} & & \multicolumn{4}{|c|}{$\begin{array}{c}\text { Percentage of Total Nitrogen, Dry } \\
\text { Weight Basis }\end{array}$} \\
\hline & & & \multicolumn{2}{|c|}{ Salwey } & \multicolumn{2}{|c|}{ Greensboro } \\
\hline & & & $\overline{\operatorname{Jan} .17}$ & Feb. 28 & Jan. 17 & Feb. 28 \\
\hline $\begin{array}{l}\text { Ringea } \\
\text { Not Finged }\end{array}$ & $\xi$ & $\begin{array}{l}\text { Limbs on the } \\
\text { same trees }\end{array}$ & $\begin{array}{l}1.617 \\
1.798\end{array}$ & $\ldots$ & $\begin{array}{l}1.291 \\
1.572\end{array}$ & $\ldots$ \\
\hline $\begin{array}{l}\text { Ringed }+ \text { nitrogen } \\
\text { Not ringred }+ \text { nitrogen }\end{array}$ & \} & $\begin{array}{l}\text { Limibs on the } \\
\text { same trees }\end{array}$ & $\begin{array}{l}1.658 \\
2.079\end{array}$ & $\cdots$ & $\begin{array}{l}1.328 \\
1.722\end{array}$ & $\cdots$ \\
\hline $\begin{array}{l}\text { Check } \ldots \ldots \ldots \ldots \ldots \ldots \\
\text { Nitrogen } \quad \ldots \ldots \ldots \ldots \ldots\end{array}$ & & $\ldots \ldots \ldots \ldots \ldots \ldots$ & $\begin{array}{l}1.714 \\
1.942\end{array}$ & $\begin{array}{l}1.915 \\
2.081\end{array}$ & $\begin{array}{l}1.440 \\
1.609\end{array}$ & $\begin{array}{l}1.598 \\
1.703\end{array}$ \\
\hline $\begin{array}{l}\text { Ringed } \ldots \text { mitrogen } \cdots \\
\text { F noed }\end{array}$ & & $\ldots \ldots \ldots \ldots \ldots \ldots$ & $\begin{array}{r}1.639 \\
1.874 \\
\end{array}$ & $\begin{array}{l}1.748 \\
1.936\end{array}$ & $\begin{array}{l}1.209 \\
1.236 \\
\end{array}$ & $\begin{array}{l}1.248 \\
1.301\end{array}$ \\
\hline
\end{tabular}

The fruit buds borne on the main scaffold branches that had been ringed in late June, 1927, were found to contain significantly less total nitrogen during the winter of 1927-28 than the buds from similar normal limbs (Table 27). Ringing was more effective in reducing the nitrogen contained in the buds during the winter of 192728 than in the previous one. This probably was due to the difference in time of ringing. When all the branches were ringed and fertilized with nitrate the fruit buds contained significantly more total nitrogen than those of similar limbs that had been ringed but not fertilized. The data show that the Salwey buds contained a much higher percentage of total nitrogen than similar ones of the Greensboro. It should be pointed out that the water content of the buds was in the same relation as that of the total nitrogen during both winters.

TABLE 29.-Influence of Ringing and Nitrogen Applications on Total Nitrogen in 1000 Fruit Buds, January 17, $192 \mathrm{~S}$

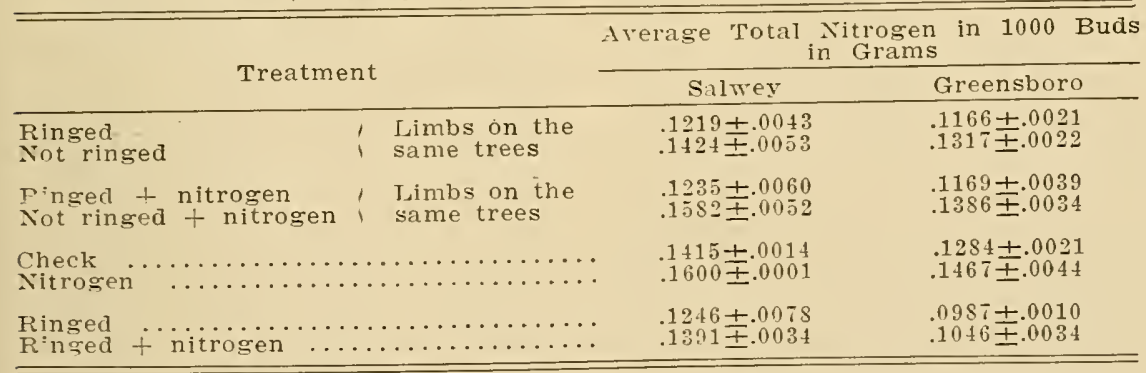

\section{Total Nitrogen in One Thousand Fruit Buds}

The total nitrogen contained in 1,000 fruit buds from the various treatments has been calculated for each of the two winters involved in the experiments. These data are given in Tables 28 and 29. Ringing had very little effect on the nitrogen content of the Salwey fruit 


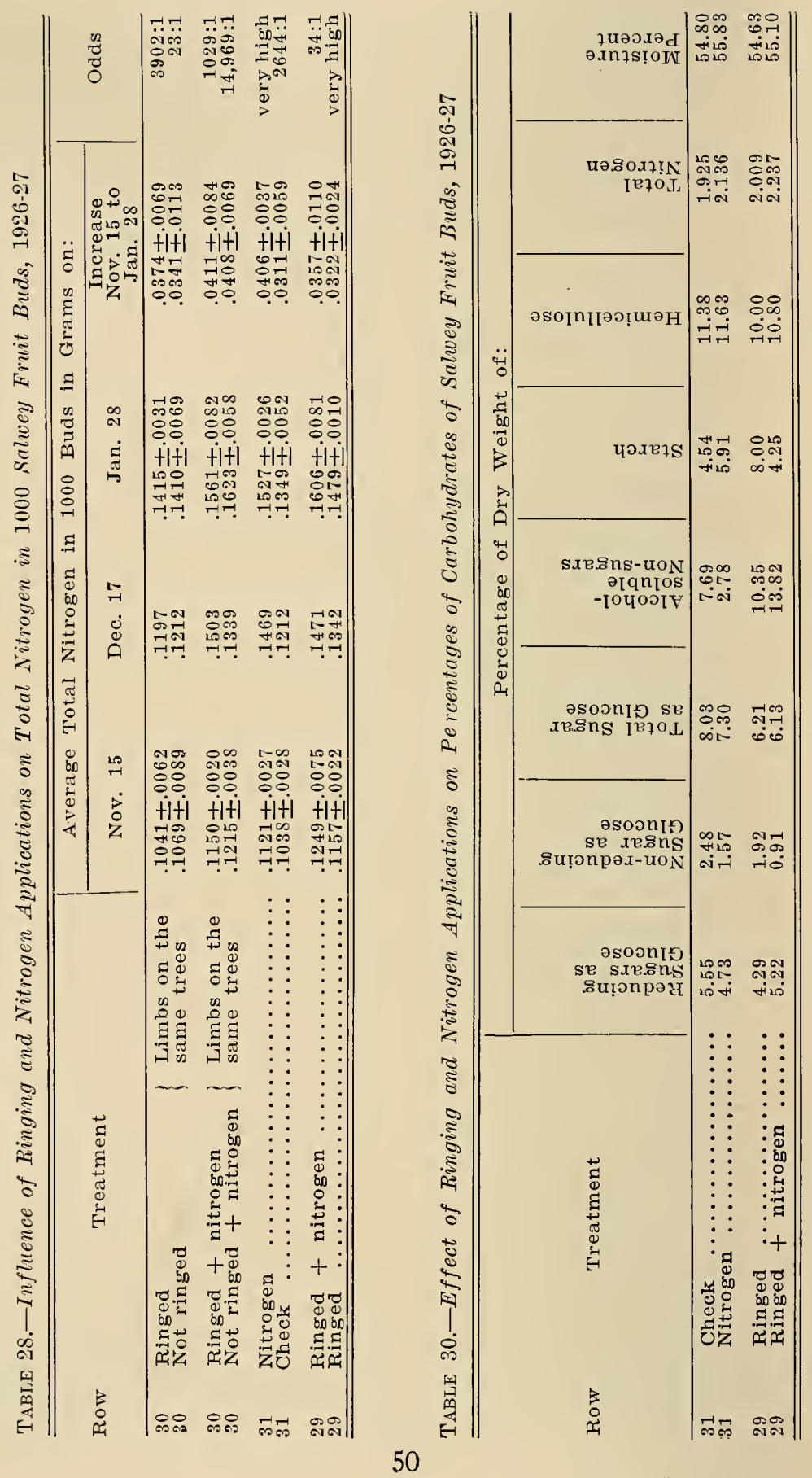


buds during the winter of 1926-27 (Table 2S). The nitrogen content of the fruit buds was very largely determined by the amount of this material available to the trees, for in every instance buds produced on fertilized trees contained more total nitrogen than similar ones not fertilized. These differences are not great enough to be mathematically significant in some cases, but in view of the data it would seem that such a conclusion is justified. There was a significant increase in the nitrogen of the buds from November 15, 1926, to January 28, 1927. However, there was very little difference between the buds from the ringed limbs and the ones not girdled in this respect. The slight increase in the percentage of total nitrogen from November to the last of January would not account for the large gain found.

It has been shown that the fruit buds increased in dry weight from 20 to 38 percent. Thus, the larger amounts of total nitrogen in the buds in late January were largely due to their growth during this period. It should be mentioned not only that there was an increase in the amounts of nitrogen in the buds from November 15 to December 17 , but also that they gained in dry weight. This is significant, since the trees are supposed to be in their deepest rest at this time of the winter. The increase in dry weight and total nitrogen of the buds from November 15 to December 17 was approximately the same as that for the slightly longer period from December 17 to January 28.

Samples were taken for moisture and nitrogen determination only on January 17, 1928, and for this reason the changes in the nitrogen content of the buds cannot be followed for the winter of 1927-28. Ringing decreased the amount of nitrogen of the buds regardless of whether all or only a part of the limbs were ringed (Table 29). The nitrogen content of the buds borne on ringed limbs was less than those of similar normal limbs or trees. Applications of nitrate of soda increased the total nitrogen content of the buds over that of similar trees not fertilized. Wide differences existed in the content of nitrogen in the buds of the Greensboro and Salwey. The Greensboro contained less moisture and nitrogen and, as will be shown later, made less growth during the winter months than the buds of the tender variety, Salwey.

\section{Composition of the Fruit Buds}

The preceding data have shown that the moisture, nitrogen, and growth relations of the fruit buds under certain conditions were materially altered by ringing and by the application of nitrate of soda. It has long been known that ringing interrupts the normal movement of carbohydrates (Curtis (24), Harvey (44), and others). In order to study the effects of ringing and nitrogen applications on the carbohydrate content of the buds, samples were taken for analysis from certain treatments on January 28,1927 . These data are given in Table 30 . Ringing had considerable influence in altering the 
carbohydrate composition of the Salwey fruit buds. This treatment reduced the percentage of total sugars present largely through its effect on the non-reducing sugars which occurred in smaller amounts.

The most striking result of the ringing was to increase greatly the percentage of alcohol-soluble non-sugars present. In this respect the composition of the buds of the ringed Salwey trees was similar to that of the hardy Greensboro (Table 16). The buds from the ringed trees were particularly high in starch, but when similar trees were fertilized the percentage of starch was greatly reduced. From this and other data already presented it is evident that the growth of the buds was determined, to some extent at least, by the amount of sugar present.

The variation in the carbohydrate composition of the buds was not as great as would be expected, considering the wide differences in growth and general behavior of the ringed trees as compared to similar ones not girdled. Each bud is composed of tissue of rapid growth and contains relatively little tissue that serves as storage organs. The growth and development of the bud is largely dependent upon the movement of food materials from the adjacent bark and wood as Curtis $(22,23)$ has shown for leaf buds. For these reasons, had analysis been made of the bark or wood adjacent to the buds, it is believed, greater differences in carbohydrates would have been found between the various treatments. The change in the general response of the trees after ringing indicates that this was true.

\section{Growth and Development of the Buds During the Winter Months}

It has been shown in the preceding pages that the fruit buds of the peach grow during the winter months and that the growth of the buds, as measured by their increase in dry matter and gain in total nitrogen, is influenced, in a measure, by the nutritional conditions of the trees during the season in which the buds are formed. To study this relation more carefully the increase in the diameter of the naked fruit buds and the development of the pollen, as influenced by the previous treatment, have been determined.

Increase in Diameter of the Naked Fruit Buds

In Table 31 are given the mean diameters and their probable errors of the naked fruit buds of the two varieties, Greensboro and Salwey, for the two periods during the winter of 1927-28. The probable errors are quite large, considering the nature of the material and the number of buds measured.

Buds produced on the basal portions of the shoots were as variable in size as those borne toward the terminals. The Salwey buds freed from scales were considerably larger than those of the Greensboro, and more variable in size. There is some indication that the buds borne on the terminal portions of the shoots were larger than those of the basal regions. However, the differences are not great enough to be significant. The basal buds were initiated first but in blooming they opened last. Thus it would seem that in early fall the 


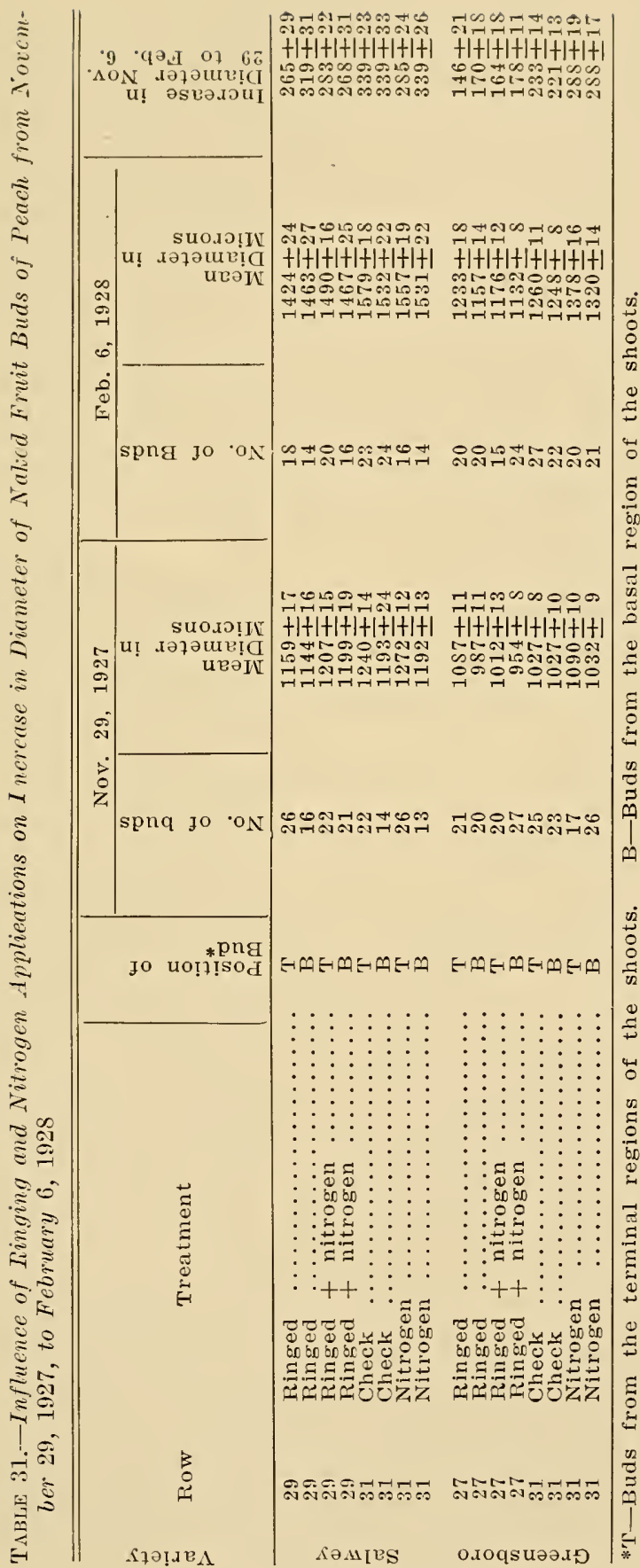


basal buds were the largest and due to the more rapid growth of the terminal buds they later exceed the former in size and development.

Practically no difference in the diameter of the buds from the various treatments within a variety was evident on November 29. By February 6 the buds of all treatments had made a significant increase in diameter. The buds of the Salwey made a greater gain in diameter than those of the Greensboro. Certain treatments caused more rapid growth than others. Ringing significantly retarded the gain in diameter of the Greensboro buds regardless of whether nitrogen was applied or not. The effect of the ringing on the Salwey was not so marked, although the buds of the ringed trees made a smaller gain in diameter than those of the checks.

When nitrate of soda was applied to Greensboro trees similar to the checks, the buds produced on the fertilized trees made the greatest growth. Similar results do not follow for the Salwey, as the buds of the checks made as large a gain in diameter as they did on the trees which received nitrate of soda.

\section{Development of the Pollen}

Fruit buds on the same tree vary considerably in the stage of pollen development. There is a marked difference between the ones borne on the terminal and basal portions of the same shoots (Table 32). This is particularly true when the observations are made in late winter. It should be pointed out that even within the same bud there is considerable variation in the development of the pollen in the various anthers. For this reason the most advanced condition found in the bud has been taken as the stage of development for the particular bud.

Very marked differences were found between the two varieties in that the range of pollen development in the Salwey was much wider than in the Greensboro. The buds of the Salwey, although initiated later in the summer than those of the Greensboro, were the most advanced on November 29. The buds of the Salwey were mostly in the late archesporial stage while the ones of the Greensboro were largely in the early archesporial stage of development. The buds borne on the terminal portions of the shoots were more advanced than those of the basal regions. The buds from the terminal region of the shoots of the Salwey from the checks and from the trees that had been ringed and supplied with nitrogen were the most advanced on November 29. The buds from the trees that had only been ringed or fertilized were retarded in development.

From this time to February 6 there was a marked change in the pollen mother cells of the Salivey buds, no matter what treatment had been given the trees. By February 6 there were wide variations in the stage of pollen development of the buds of certain treatments. The pollen of the basal buds of the ringed trees ranged in development from pollen mother cell to that of the late tetrad stage, and the terminal buds of the check trees presented similar conditions. At this time the basal buds of the ringed Salwey trees were more 


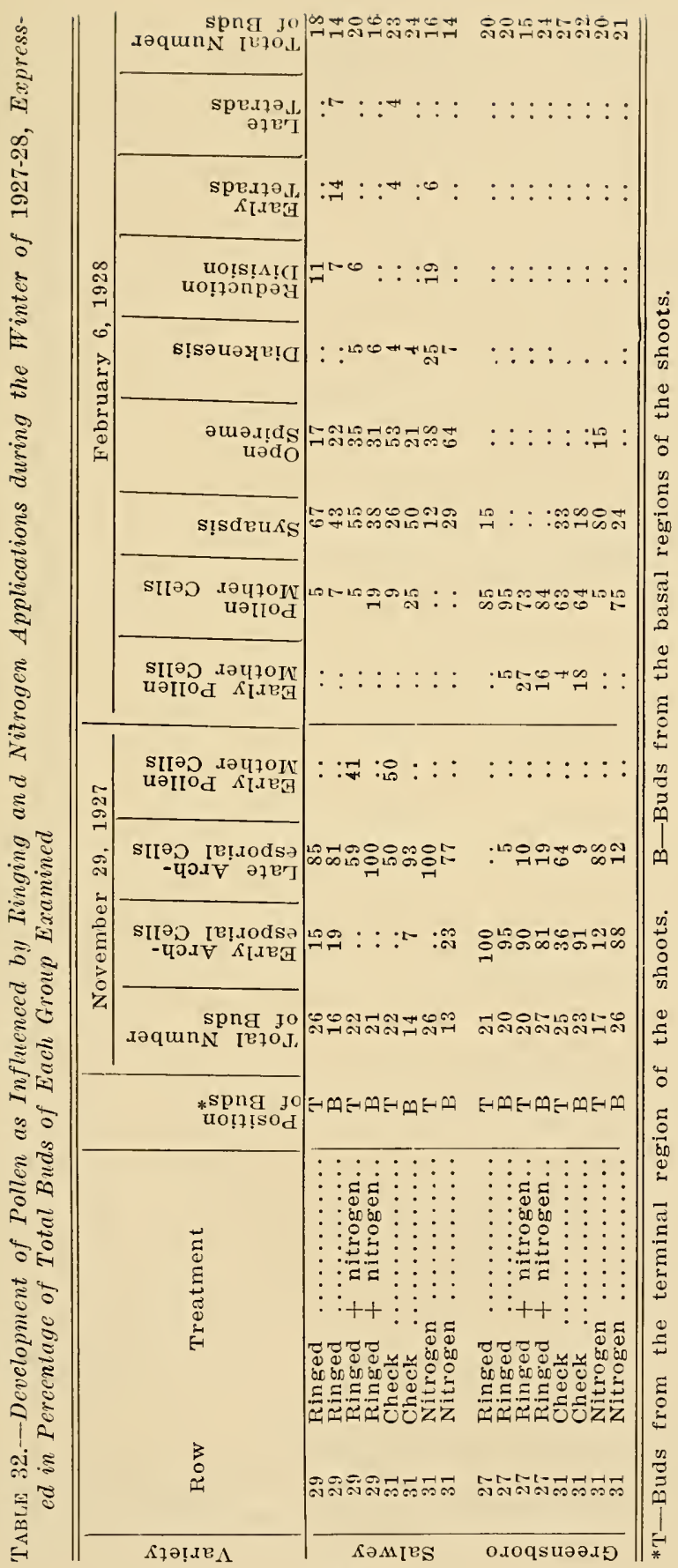


advanced than the ones borne on the terminal portions of the shoots. The terminal buds of the checks and the trees that received nitrogen were the most advanced. Although the data are not entirely clear it appears that the buds of the ringed trees, taken as a whole, as measured by pollen development were less advanced, and the ones receiving only nitrogen were, generally, more advanced than those of the check trees.

Taken as a whole, the buds of the fertilized Greensboro trees were more advanced on November 29 than those of the checks. The effect of ringing was to retard pollen development. By February 6 the pollen had developed materially and the growth of the buds had continued in about the same order as that found on the earlier date. That is, the buds of the fertilized trees were the most advanced, followed by the ones from the checks. When the trees were ringed and fertilized, the buds were less advanced than when they were only girdled. No explanation is available for this at present.

It would seem that, in general, fertilization with nitrate hastened and ringing retarded the development of pollen. The wide difference in the stages of pollen development between the two varieties should be pointed out. In every instance the pollen of the Salwey fruit buds was much more advanced than that of the Greensboro. This is very significant and lends emphasis to the view that the hardiness of the Greensboro is due, at least in part, to the slow growth of the buds during the winter months.

\section{DISCUSSION}

In these experiments ringing the main limbs of the trees about the middle of June did not have any material effect on the formation of fruit buds. The Salwey trees that received an application of nitrate of soda at bloom set a greater percentage of fruit buds in both years than similar trees not fertilized. In general, the fertilized Salwey trees formed as large a percentage of fruit buds as did those that were ringed and nitrated. It would appear then that ringing did not prevent the movement of nitrogen to the shoots, or that the trees were ringed too late to influence the formation of buds. It would seem that the latter view is the more probable.

These results lend emphasis to the view that fruit-bud formation is determined earlier in the growing season than has been evident from microscopical examination of the buds. The Salwey trees ringed on June 11, 1926, formed the same percentage of buds on the long shoots as on the short ones. The number of fruit buds on the normal trees decreased as the length of the shoots increased. It appears that ringing done at that time was sufficiently early to influence the formation of buds toward the apex of the long shoots but was without effect on the short ones.

Due to favorable weather conditions during both winters the injury to the fruit buds was not sufficiently severe to bring out the differences in the hardiness of the buds of the various treatments. The 
data presented seem to show that the conditions that caused an accumulation of carbohydrates increased the hardiness of the buds. The hardiness of the buds of both varieties was significantly and negatively correlated with the length of the shoot on which the buds were produced. Then the nutritional conditions that cause some shoots to grow long and others short have an effect on the hardiness of the buds. It has been shown that the tender buds were high in moisture and nitrogen.

Ringing the trees in June materially reduced the percentage of water and nitrogen in the buds as well as the percentage of total sugars present, and increased the amounts of alcohol-soluble nonsugars. It would seem that the food reserves of the ringed trees were less readily available for growth than those of the checks. The buds on ringed limbs made less growth as measured by the increase in dry matter, less gain in diameter of the naked buds, and slower development of the pollen during the winter months than the ones produced on similar trees or limbs not ringed. This is in agreement with the results reported by Summers (85), that the buds on ringed shoots of the cherry, apple, and pear are retarded in their development above the ring and accelerated for some distance below it.

\section{PART III}

\section{The Influence of Partial Defoliation and Nitrogen Applications on the Formation, Growth, and Hardiness of Peach Buds}

Under field conditions partial defoliation of peach trees occurs as the result of insect, disease, or spray injury. In some instances this partial defoliation has been considered to influence the susceptibility of the fruit buds to winter injury. On the other hand, Roberts (76) has reported that partial defoliation of cherry trees under certain conditions resulted in hardy buds. Conditions that prematurely remove the leaves usually reduce the amount of carbohydrates available to the trees. This may result not only through decreased photosynthesis but also from increased or prolonged growth of the trees, which may follow the defoliation, as has been shown by Harvey (44). Prolonged or late growth involves the utilization of food materials and at the approach of winter less carbohydrates would be stored than in the case of trees making a normal growth. From this it could be deduced that tender buds would result from defoliation, since the tissues would be immature at the approach of winter, and the tissues probably would be relatively high in water and nitrogen and low in carbohydrates. In order to determine the effects of partial defoliation on the hardiness of peach fruit buds the following treatments were used.

\section{Treatments}

Experiments on partial defoliation were made only during one year. In order to insure the formation of fruit buds the trees were not defoliated until the very young buds were visible. Approximately 
three-fourths of each leaf on one-half of each Salwey tree and on one of the four main scaffold limbs of each Greensboro tree were removed by cutting the leaf blade at right angles to the mid rib. The Greensboro trees were partially defoliated on July 21 and 22, and the Salwey on August 18 and 19, 1927. Following this partial defoliation the branches so treated started growth and put out new leaves at the terminals, which were removed from time to time. The previous treatments as well as the ones employed are given below.

Row 27. Salwey: 1925, Light dormant and two summer prunings. 1926, Corrective and two summer prunings. 1927, Corrective pruning and one-half of the main branches of each tree partially defoliated on August 17 and 18.

Row 28. Greensboro: 1925, Heavy dormant pruning. 1926, Corrective pruning. 1927, Corrective pruning and one main branch on each tree partially defoliated on July 21 and 22.

Row 31. Greensboro: 1925, Light dormant pruning. 1926 and 1927, no treatment. These trees were used as checks.

Salwey: Same as the Greensboro.

A standard 4-pound application of nitrate of soda was made at the time of blooming to every other tree in all rows.

\section{EXPERIMENTAL RESULTS}

The effects of the partial defoliation and nitrate applications on the growth of the trees and the formation and hardiness of the buds have been determined. Consideration has also been given to the effects of the treatments on the dry weight and total nitrogen content of the buds, as well as on the growth of the buds and pollen.

\section{Growth and Blooming Response of the Trees Following Partial Defoliation}

Soon after the branches were partially defoliated they started into growth and produced new leaves at the terminals, which were removed from time to time. The parts of the trees not defoliated were influenced by the partial defoliation of the limbs on the same tree to some extent, as the leaves became darker green in color and were retained later in the fall than leaves on similar trees not defoliated. Terminal growth on the partially defoliated branches continued late in the fall with the result that the shoots were very slender. The bark of these shoots was a brownish-green color entirely free of any bright pigments.

The following observations on leaf fall of the two varieties were made on November 7, 1927: Practically all the leaves of the Greensboro trees had fallen. What few leaves remained on the trees were on the branches that had been partially defoliated. The leaves on the partially defoliated branches of the Salwey trees were still dark green, and none or very few had fallen, while limbs on the same trees not defoliated retained about half their leaves which were still green. 
The foliage of the untreated Salwey trees was yellow and about twothirds or more had fallen, while similar trees that had been fertilized with nitrate of soda retained from one-half to two-thirds of the leaves. During the winter many of the tips of the shoots of the partially defoliated branches of the Salwey trees were killed, and usually about one-third of the shoot was injured, but on the defoliated and fertilized trees the injury was more severe.

From the data and from observations in the field it seems that the terminal portion of the shoots of the defoliated branches are more tender than the fruit buds. Because of this injury to the shoots the data to be presented later do not show the real differences that exist between the treatments, since in making the observations on injury only shoots that did not show injury were used.

The various treatments markedly influenced the time of blooming. As previously stated the Salwey trees left as controls blooned about two days earlier than similar Greensboro trees. Blossoms appeared first on the branches of the partially defoliated trees. In this connection it is well to point out that some small branches below the rings on the ringed limbs bloomed at about the same time as the partially defoliated ones. The buds on the defoliated limbs opened from two to three days earlier than those on branches of the same trees which had not been defoliated. The latter bloomed slightly in advance of the trees that had been fertilized and these were closely followed by the checks.

These observations do not agree with those reported by Cooper and Wiggans (18), since they found that the untreated trees came into bloom from one to three days earlier than the trees treated with nitrate. They also report that the buds of the untreated trees because of their advancement were more readily injured by the early spring freezes than the buds of treated trees. Chandler (15) also reports that late cultivation caused delayed blooming of peaches. The delayed flowering of the treated trees reported by Cooper and Wiggans and by Chandler may be due to a larger food storage than in the case of the untreated ones. The untreated trees may have had more wood and fruit to be supported per unit of leaf area, which resulted in storage of less food than in the case of the treated trees.

In view of the results reported in this paper it is to be expected that the buds on trees relatively low in soluble carbohydrates would make the least growth during the winter and bloom late in the spring. It would seem that this is the explanation rather than that fertilization or cultivation delays the inception and the breaking of the rest period. The treatments used in this study were designed to delay maturity and the entrance into the rest period. Nevertheless the buds from such trees made a greater growth and development during the winter than those of similar trees which are assumed to have entered the rest period earlier. It has been the writer's experience that such practices as summer pruning hasten the blooming of the trees in the following spring. This is probably due to a smaller carbohydrate storage than is, the case in dormant pruned trees. 


\section{Formation and Hardiness of the Fruit Buds}

In Table 33 are given the data for the formation and hardiness of the fruit buds as influenced by partial defoliation and nitrogen applications.

\section{Fruit-Bud Formation}

Partial defoliation had no effect on the percentage of fruit bud formation on the Salwey, but slightly decreased it on the Greensboro. Fruit bud initiation had probably proceeded farther at the time the Salwey trees were defoliated than with the Greensboro, since the trees of the latter variety were defoliated almost a month before those of the Salwey. Ringing the main branches on June 20 to 21 resulted in only a slight increase in fruit-bud formation in some cases, and it was suggested that this practice was done too late to influence the setting of buds except perhaps on the long shoots (Part II). The slight decrease in fruit-bud formation on the Greensboro following partial defoliation would seem to be a contradiction to the explanation offered for the effects of ringing. In the case of partial defoliation it is reasonable to assume that, even though fruit-bud formation had been initiated at the time of defoliation, the subsequent lack of carbohydrates limited the percentage of Greensboro buds that developed.

\section{Hardiness of the Buds}

It was unfortunate, as far as this study is concerned, that severe weather conditions were not experienced during the winter of 192728. The data of Table 33 show that partial defoliation had no effect on the percentage of the buds of either variety tinat came through the winter uninjured. The striking difference brought out by the data is the great amount of pistil killing of the buds of the Salwey that did not receive nitrate of soda. This injury was caused by low temperature in March following a warm period, as already pointed out. In every instance the pistils of the buds of nitrated trees suffered less injury than those not nitrated.

Limbs that had been partially defoliated had a lower percentage of buds with their pistils killed than similar ones not defoliated on the same trees. In this respect partial defoliation caused the buds to be more resistant to injury than the ones produced by a normal leaf area. When the percentage of the buds that were alive is added to the percentage of buds with the pistils killed the data show that defoliation caused the buds to be more tender than the ones borne on normal branches of the same trees.

The buds on the partially defoliated limbs were as hardy as those of the checks. Very little difference in hardiness or in the amount of pistil injury to the buds of the Greensboro was evident. There is some indication that the nitrate of soda applications or the partial defoliation by accelerating the development of the buds caused 


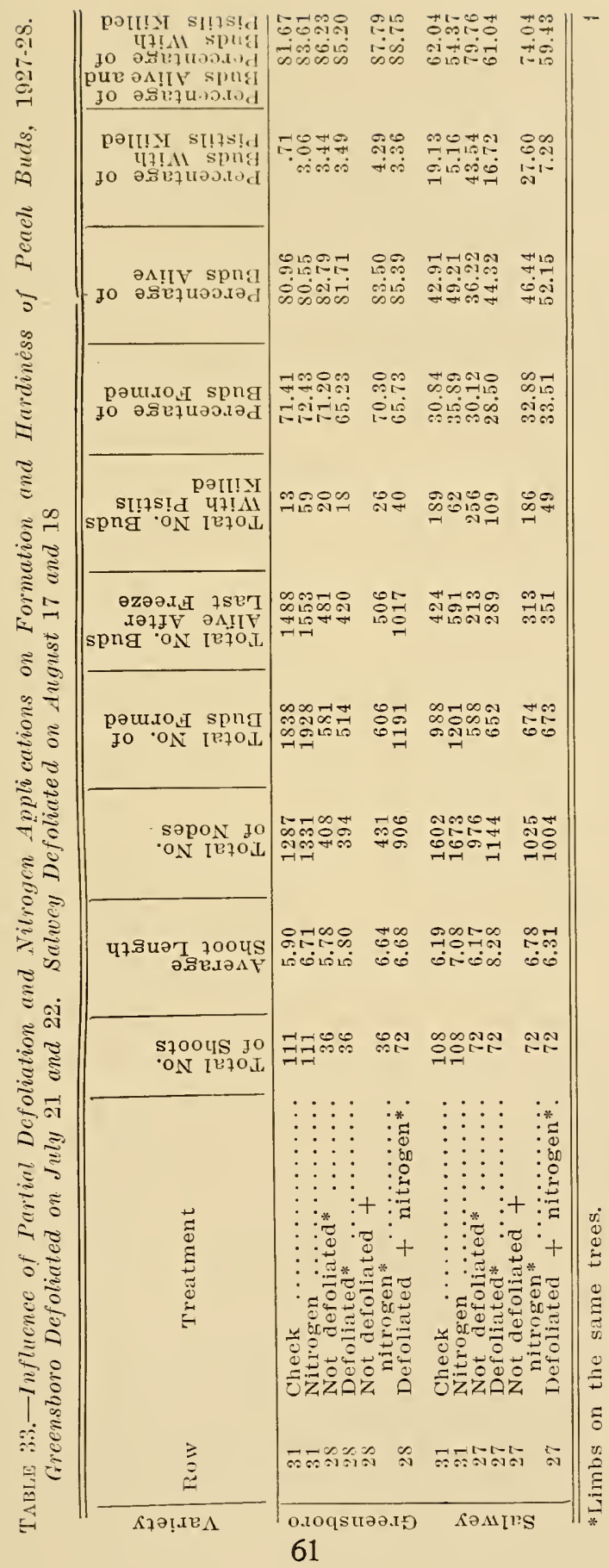


the pistils of this variety to be more susceptible to freezing injury than those of the checks.

\section{Dry Weight of the Fruit Buds}

In Table 34 are given the data on the percentages of dry weight and the dry weights of 100 fruit buds from the various treatments. These data show that partial defoliation decreased the percentage of dry weight of the fruit buds of both varieties, but more significantly in the case of the Greensboro than with the Salwey. It has been shown that nitrate of soda applications decreased the percentage of dry weight of the buds. In this respect defoliation had a similar effect. The percentage of dry weight of the fruit buds of the defoliated branches or of those not defoliated on the same trees was not influenced by the treatment with nitrate. It has been shown in Parts I and II that hardiness of the buds was negatively correlated with their moisture content. It would seem then that in winters of low temperatures the buds of the partially defoliated trees would be more susceptible to winter injury than those produced on trees bearing a normal leaf area.

A striking effect of partial defoliation was to reduce the weight of the fruit buds (Table 34). In all cases the buds produced on the partially defoliated limbs were significantly smaller than those borne on limbs of the same trees which carried a normal leaf area. These data emphasize the fact that the fruit buds depend to a considerable degree upon the leaf area subtending them for their food supply.

\section{Percentage of Total Nitrogen in the Fruit Buds}

In view of the vegetative condition of the partially defoliated limbs it was suspected that the fruit buds contained a high percentage of total nitrogen. Harvey and Murneek (45), working with dedefoliated apple spurs, found a narrow carbohydrates-nitrogen ratio which was due to an increase in the amount of nitrogen and reduction in the polysaccharides, although the amount of reducing sugars was increased to such an extent that the total carbohydrate content was but slightly altered by the defoliation.

When analyses were made of the fruit buds it was found that the buds borne on the partially defoliated limbs were lower in total nitrogen than those borne on the normal limbs of the same trees (Table 35). It should be pointed out that it is not entirely permissible to compare the results of the partially defoliated limbs or those of the same trees not defoliated with the checks, for the reason that the partially defoliated trees had been pruned each year before these studies were started. The data show, nevertheless, that partial defoliation reduced the percentage of total nitrogen in the buds as compared to that in the buds from limbs on the same trees not defoliated. This probably is due to the fact that the defoliated branches continued terminal growth too late in the fall. This would result in a utilization of the nitrogen in new leaf and shoot formation rather than in fruit-bud formation. 

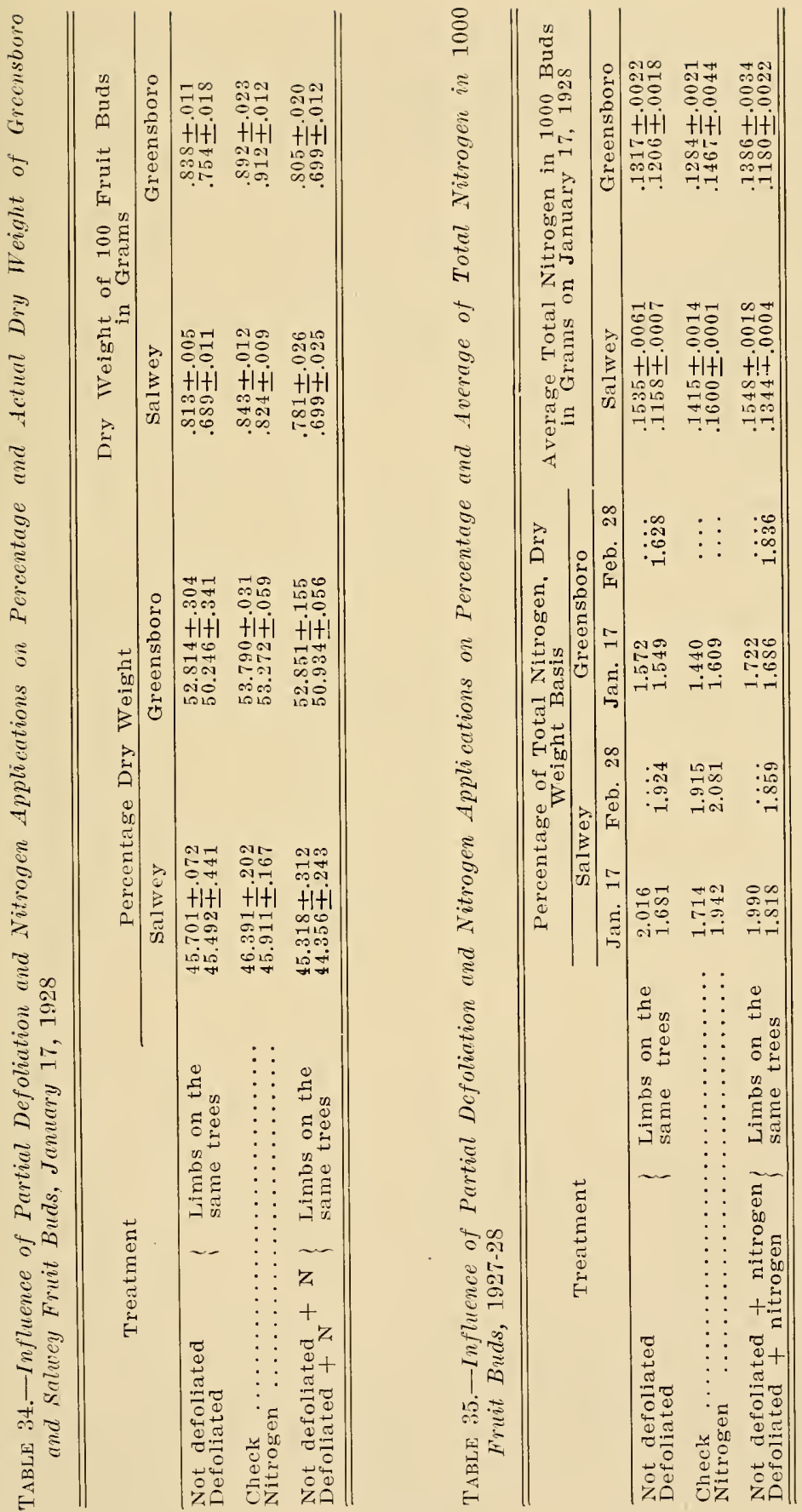


\section{Total Nitrogen in One Thousand Fruit Buds}

In order to show clearly the effects of partial defoliation on the total nitrogen content of the fruit buds, the amount of nitrogen contained in 1000 buds has been calculated and the data are given in Table 35. In every case the buds from the defoliated limbs contained significantly less total nitrogen on January 17 than the ones from the branches on the same trees which were not defoliated. The late growth of the partially defoliated branches had apparently used up the nitrogen, with the result that the buds were low in this material. The partial defoliation of a part of the branches on the trees influenced the amount of total nitrogen in the buds on the branches which had not been defoliated. In all cases the buds from the branches bearing a normal leaf area but from trees on which a part of the limbs were partially defoliated contained about the same amount of total nitrogen regardless of whether the trees had been fertilized or not. The amount of total nitrogen in the buds from these undefoliated branches was slightly less than in those from trees which received only nitrogen. These data show that defoliation of a part of the trees alters the nitrogen relations in the branches bearing a normal leaf area.

\section{Growth and Development of the Fruit Buds}

To determine the effects of partial defoliation and applications of nitrate of soda on the growth and development of the fruit buds during the winter months, samples of buds from the various treatments were collected for histological studies on November 29, 1927, and on February 6, 1928. To follow the changes that took place in the buds during this time two measures of growth have been used; the increase in the diameter of the naked fruit bud measured in that region where a straight line would bisect the ovules, and the development of pollen. These data are given in Tables 36 and 37.

\section{Increase in Diameter of the Naked Buds}

It has been shown that the buds produced on the partially defoliated branches weighed less than those borne on the same trees but on normal limbs. When the actual diameter of the naked buds is considered it was found that those borne on the partially defoliated shoots were as large on November 29 as those on the same trees produced by a normal leaf area (Table 36). By February 6 the buds of partially defoliated branches had increased in diameter until they were larger than the ones borne on the normal shoots. It is not possible to explain this difference in the size of the buds as measured by the two methods. The higher water content of the buds from the partially defoliated branches will not account entirely for this difference in size as determined by the two methods employed. The structure of the buds may have been changed by the partial defoliation, as observations in the field showed that these buds were the smallest, and in removing the scales from the buds there appeared to be fewer scales than when the buds were producd under normal conditions. 


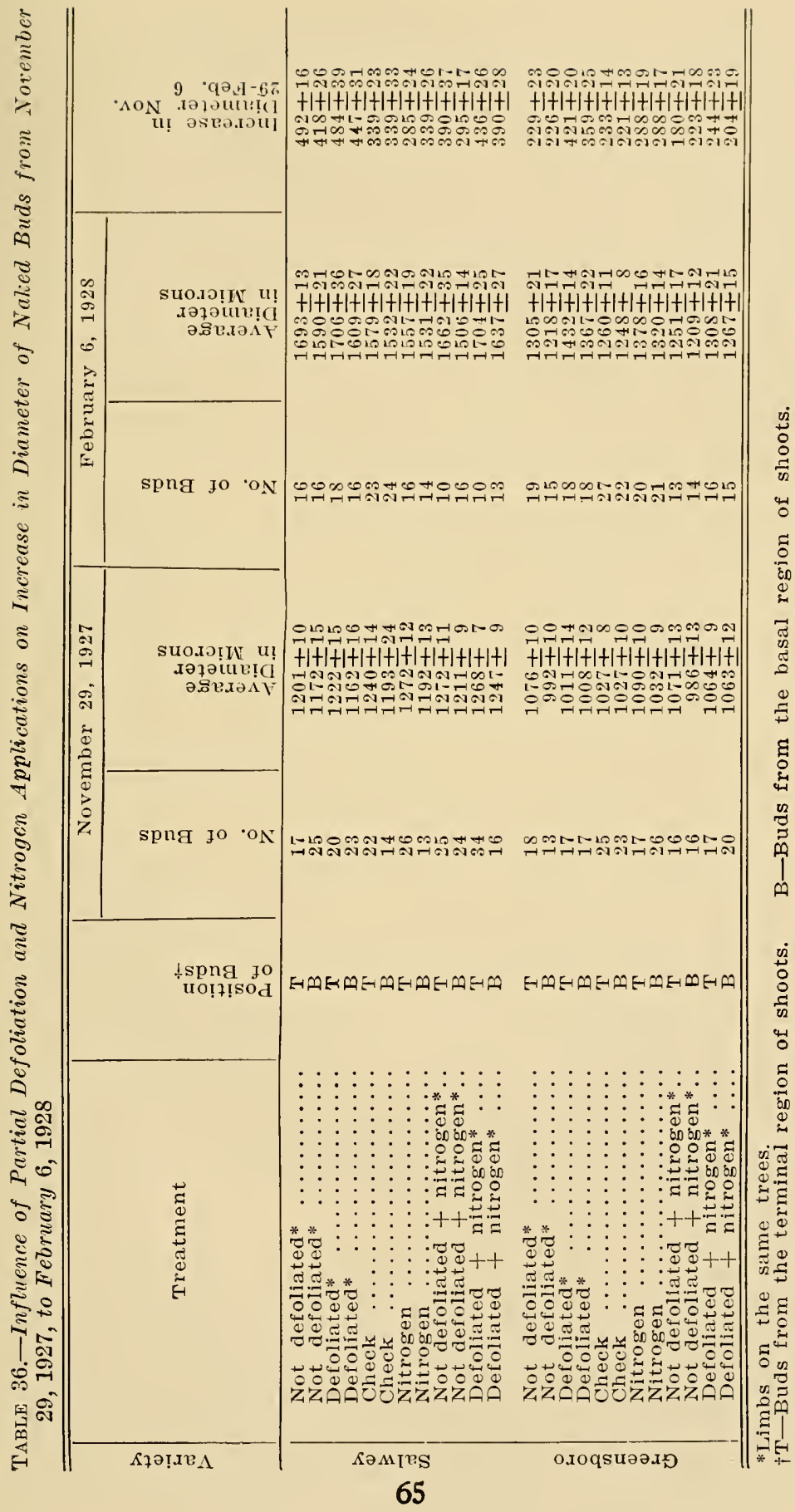


In no case was there any marked difference in the diameter of the buds from the various treatments on November 29. It seems that the buds borne on the terminal portions of the shoots were larger at this time than the basal buds. This is more clearly evident on February 6. In some instances the differences between the average diameters of the terminal and basal buds are too small to justify this statement, especially when the probable error is considered. The data would indicate that this was true, for in no instance was the mean diameter of the terminal buds smaller than that of the basal ones and in only three cases were they of approximately the same size.

There was a highly significant increase in the diameter of the naked buds of all treatments from November 29 to February 6. There were marked differences in the gains in diameter of the buds of Greensboro and Salwey. The Salwey buds made more growth than the Greensboro buds. This difference in the growth of the buds is very clearly one of the distinguishing varietal characteristics which accounts, in part, for the hardiness of the Greensboro.

Rather marked differences in the gain in diameter of the buds existed between the various treatments within the variety. The buds produced on the partially defoliated shoots of the Salwey made the greatest gain in diameter of all the treatments. When nitrogen was applied to similar trees there was some indication that the buds of both varieties made a smaller increase in diameter than when the trees were fertilized and the branches partially defoliated. It has been shown that the buds from partially defoliated branches contained a smaller percentage and less total nitrogen than the ones from the same trees but from limbs bearing a normal leaf area.

There is a relation between the nitrogen content of the buds and their gain in diameter as has been shown to exist between nitrogen content and the increase in dry weight. It seems that in the case of the branches partially defoliated on trees treated with nitrate that the food materials have been used in wood or leaf growth at the expense of the buds, which results in a smaller gain in diameter of the buds during the winter months. There is very little difference between the increase in diameter of the buds borne on the terminal or basal portions of the shoots. The data of Table 36 do not show, perhaps, the true differences that exist between the various treatments for the reason that when the samples were taken on- February 6 a considerable number of the buds produced on the terminal portions of the shoots were dead and had to be discarded.

\section{Development of Pollen}

Previous work has shown that the fruit buds of the peach are variable in size, in water, and in nitrogen content and that these characters are determined, in part, by the growth conditions of the trees during the season when the buds are formed. It has also been shown that the buds grow during the dormant season and that this growth of the buds as measured by the increase in dry matter and gain in total nitrogen is related to the nutritional conditions of the 


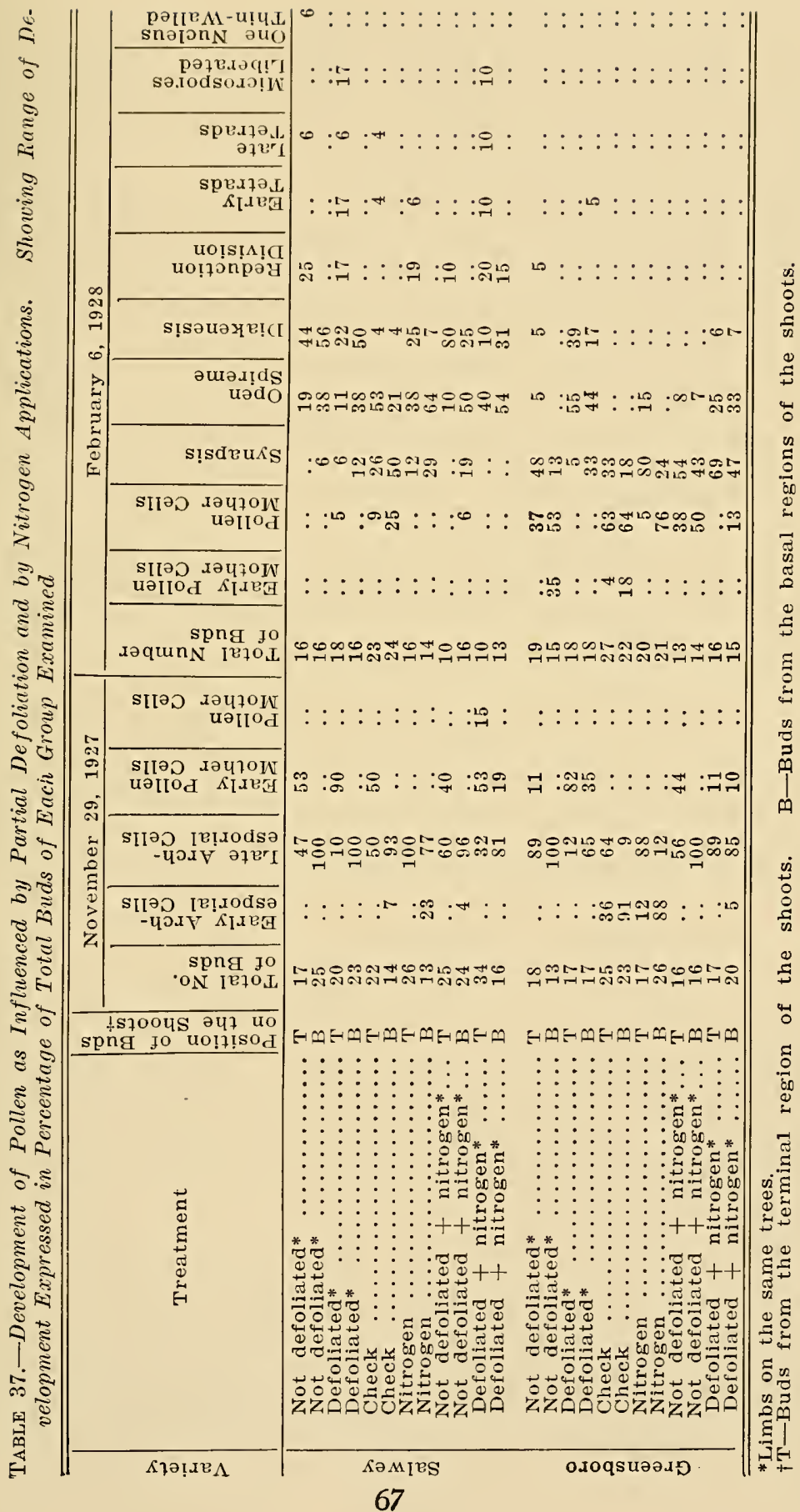


trees (Parts I and II). The effect of partial defoliation and nitrate applications upon the development of the pollen has been observed.

Realizing that only a relatively small number of buds could be examined by the tedious methods used, care was exercised in the collection of the samples so that they represented, as far as possible, the mean of the treatments. This was not possible with all of the samples taken on February 6, as there were many dead buds particularly on the shoots that had been partially defoliated. The largest number of dead buds were found on the terminal regions of the shoots, regardless of whether they had been fertilized or not.

Data for the development of the pollen in the buds from the various treatments are given in Table 37: These data show that the buds produced on the partially defoliated branches or on branches on the same trees not defoliated were the most advanced on November 29. The buds from the fertilized trees were slightly more advanced than those of the checks. In other words, the buds of the checks were the most retarded, and the pollen development of the buds of the other treatments followed rather closely the growth of the trees during the previous growing season. In general, the treatments that prolonged the growth of the trees hastened the development of pollen.

The buds borne near the terminals of the shoots were more advanced in pollen development than the basal ones. On November 29 the stage of pollen development of the two varieties was nearer the same than would be expected, considering the fact that the fruit buds of the Greensboro are initiated earlier than those of the Salwey. The Salwey buds on November 29 were slightly more advanced than those of the Greensboro. This shows that the buds of the Salwey develop much more rapidly than those of the Greensboro.

From November 29 to February 6 very significant changes took place in the pollen development in both varieties under all treatments. One of the most striking relations brought out by the data is the great difference in the development of the pollen of the Salwey as compared to that of the Greensboro. Although comparatively little difference between the two varieties was evident on the earlier date, by February 6 the buds of the Salwey were much farther advanced than those of the Greensboro. The rapid growth of the Salwey fruit buds explains, at least in part, the difference in the hardiness of the two varieties.

The data show marked differences between the various treatments within a variety in the development of the pollen. The buds from the partially defoliated trees were found to be more advanced than those from the checks. Partial defoliation of a part of a tree hastened the pollen development of the buds borne on the branches not defoliated but on the same trees. The buds produced on the defoliated branches were, however, more advanced than those from the same trees but borne on limbs that had not been defoliated, 
It has already been pointed out that fertilization with nitrate of soda accelerated the development of the buds. When branches on trees treated with nitrate were partially defoliated the buds were not as far advanced as those on trees that had not received the nitrogen. It has been shown that defoliation and nitrogen applications reduced the gain in diameter of the buds from November to February as compared with those from similar partially defoliated trees which were not fertilized. The only explanation that can be offered for the slower pollen development of the buds borne on partially defoliated branches on trees that had been nitrated is that, probably, the food reserves were used $u p$ in the late growth of these trees and there was less food stored at leaf fall than in the case of similar ones not fertilized. The nitrogen content of the buds of defoliated and fertilized trees was less than that of the ones not fertilized and in view of the relationship that has been shown to exist between the nitrogen content and the increase in dry weight of the buds, the slow development of the former may have been due to the smaller amount of nitrogen present.

The buds borne on the terminal portions of the shoots were more advanced in pollen development than those of the basal regions. This agrees with the results reported by Knowlton and Dorsey (56). Chandler (16) reports that the basal buds were more resistant to winter injury than those close to the terminals of the shoots. These relations indicate that the nutritional conditions existing in the various portions of the shoots influence the development of the pollen of the buds. The buds borne on the terminal portions of the shoots were generally more variable in development than those close to the base. It should be pointed out that the buds of the Salwey were more variable than those of the Greensboro. It appears that this variability in development is associated with susceptibility of the buds to winter injury.

\section{DISCUSSION}

Partial defoliation of certain branches, in July and August, after fruit bud formation had started resulted in renewed growth of the shoots of both varieties. These limbs retained their foliage late in the fall and the shoots were lacking in red pigments. The shoots were very slender and failed to increase in diameter, which is in accord with the results of Proebsting (\%4), working with defoliated apple shoots. Considerable winter injury to the tips of the partially defoliated shoots occurred,--probably the result of immaturity caused by the late growth.

Partial defoliation slightly reduced the formation of fruit buds on the Greensboro but had little effect on the Salwey. Fruit bud initiation had probably proceeded to a greater extent in the Salwey, as the buds were allowed to develop far enough to be seen before the trees were defoliated. 
The data presented show that partial defoliation had some effect on increasing the percentage of the buds that were injured by freezing temperatures. There were marked differences between the various treatments of the Salwey in the amount of winter injury to the pistils of the buds caused by a temperature of $23^{\circ} \mathrm{F}$. in March, following a warm period. The buds of the trees that had been fertilized with nitrate were injured to a less extent than those not fertilized. It seems that the greater resistance of the pistils of the buds of the fertilized Salwey trees toward injury by freezing was due to the advanced stage of development of these buds at the time the low temperature occurred.

Partial defoliation materially reduced the percentage of dry weight of the buds. In view of this and the degree of correlation that has been shown to exist between the percentage of moisture of the buds and their hardiness it is believed that the buds of the defoliated branches were susceptible to injury at least in part because of their high water content.

The growth of the buds, as measured by their increase in diameter, was accelerated by partial defoliation. When the trees were fertilized and some of the branches partially defoliated, the buds produced did not gain in diameter as rapidly as those from the limbs that had only been defoliated. This was associated with the low nitrogen content of the buds and possibly with a low supply of food materials essential for growth. It is to be expected that when subjected to low temperatures the buds of partially defoliated and fertilized branches would be injured more than those not fertilized because of a greater degree of immaturity.

Partial defoliation not only accelerated the growth of the buds but it hastened the development of the pollen during the winter months. The fruit buds borne on the terminal portions of the shoots were more advanced than those produced toward the base. Knowlton and Dorsey (56) found the same relation to exist between the basal and terminal buds of other varieties. Abbott (1) cites some unpublished work of Hooker, who found that the basal buds contained less nitrogen and phosphorus but more water than the distal buds, and that the nitrogen and phosphorus increased from a low percentage in early fall to considerable amounts by the last of January.

Anderson and Hooker (3), working with the cherry, showed that there was translocation of nitrogen from the other portions of the tree to the leaf and fruit buds. They found more nitrogen and water in the buds of the terminal region of the shoots than in those of the median or basal sections. Summers (80), using apple shoots in which he injected various sugar solutions, found that the development of the buds was accelerated in all instances and that the ones nearest the points of injection made the earliest response. 


\section{GENERAL DISCUSSION}

The data presented in the preceding pages on the influence of various practices on the formation, composition, and hardiness of the fruit buds of the peach show some irregularities which make the drawing of trustworthy conclusions difficult. During two of the three years in which these studies were made the winter conditions were so mild that there was comparatively little injury to the buds, and the data do not show, perhaps, the true difference in hardiness that existed between the various treatments. The data have, however, brought out some differences between the two varieties and between the various treatments within the variety which offer an explanation for some of the variations in hardiness of the fruit buds of the peach that are often observed in the field.

It has been shown that there is a wide difference between the Greensboro and Salwey varieties in the hardiness of the fruit buds, the former being much hardier than the latter. 'The hardiness of the buds is, in large part, determined by the moisture, nitrogen, and carbohydrate relationships which influence the growth of the buds during the dormant season. The buds of the Greensboro have been shown to be much lower in mosture, total nitrogen, and reducing and total sugars than the tender Salwey buds. Because of these relationships the buds of the former variety make less growth during the winter months than the Salwey.

It has been shown that the hardiness of the buds in both varieties is negatively correlated with the length of the shoot on which the buds are borne. The lack of hardiness is probably due to the more rapid growth during the winter of the buds on the long shoots as compared to those on the short ones. Knowlton and Dorsey (56) showed that the buds produced on long shoots are farther advancer during the winter than those borne on shoots less than six inches in length. The difference in the growth of the buds is determined, at least in part, by their water and nitrogen content, or by the nutritional conditions that made the long shoots grow long. On the same shoot the buds borne on the terminal portions are more tender than those of the basal regions. Data presented have shown that the buds borne near the terminals of the shoots are more advanced in development than are those near the base, which is in agreement with the results of Knowiton and Dorsey $(56)$. The more rapid the growth of the buds on the terminal portions of the shoots has been showil to be due probably to a higher moisture, nitrogen, and sugar content than that of the basal buds. 
It was not possible, with the methods employed in this study, to increase the hardiness of the Salwey fruit buds so that it even approached that of the Greensboro, although the various practices used appreciably influenced the harcliness of the buds within the variety. Neither was it possible to change the moisture, nitrogen, and carbohydrate relationships of the buds of the Salwey so that they approximated those of the Greensboro. The treatments that caused the trees to be vegetative increased the percentage of water and nitrogen in the fruit buds. The treatments that reduced the vegetative conditions of the trees decreased the percentage of water and nitrogen present in the buds. It was not possible to build up a nitrogen or water content in the Greensboro buds to equal that of the Salwey.

It is believed that the greater growth response of the Salwey was due to the higher moisture, total nitrogen, and sugar content of the buds as compared with that of the Greensboro. The practices that increased these materials in the buds accelerated their development and reduced their hardiness. It was not possible to retard the growth of the Salwey buds so that they made the same growth response as the Greensboro which is probably due to the difference in the chemical composition of the two varieties.

From the data presented it appears that the conditions which accelerate the growth of the trees during the season when the fruit buds are formed likewise increase the growth and development of the buds during the dormant season. In no instance was there any evidence that would support the idea that late growth of the trees, within a variety, delayed the entrance of the buds into and their coming out of the rest period which was thought by Chandler (15) to be associated with the hardiness of the buds. From the data presented it seems that the rest period does not have a controlling influence on the growth of the buds but that they continue to grow and develop throughout the winter.

It has been shown by several investigators that the rest period of the peach is short and easily broken and often ends by the last of December or the first of January. Knowlton and Dorsey ( 56 ) found that the buds of the varieties Belle and Rochester made a slower growth response during the winter than did those of Elberta, which they thought was due to the shorter rest period of the latter variety. This, however, is a question of varietal difference and not one of influencing the rest period of the variety. It has been shown that low moisture, total nitrogen, and sugars are associated with retarded development of the buds, which may be due to a longer rest period or to the inhibition of growth caused by the accumulatior. of carbohydrates or other agents influencing protoplasmic activity.

Some evidence was found that the production of a crop of fruit caused the buds to be tender. This is in agreement with the results reported by Chandler (16), who showed that removing the fruit by thinning increased the hardiness of the buds. The production of a crop of fruit apparently removes the carbohydrates and other food 
materials in the fruit which are not replaced before leaf fall and result in buds susceptible to injury from cold. It appears that tender buds may result from a small leaf area per unit of tissue that must be supported during the winter. In other words, within a variety and for winter conditions even as mild as those of West Virginia the greatest degree of hardiness of the fruit buds of the peach is to be secured through the elaboration and storage of large amounts of food reserves.

The results of these studies suggest some procedures that should be followed in peach orchard management in order to secure the maximum resistance of the buds to winter injury. Since the greatest degree of hardiness was found in those cases where there was the greatest storage of food reserves it follows that a large and healthy leaf area should be maintained late into the fall. This can be accomplished by judicious cultivation, pruning, applications of nitrogen, and by the adequate control of insects and disease. Cultivation or the application of nitrogen carrying fertilizers should be made early in the spring to stimulate a quick growth of the trees and to produce a thrifty leaf area. The trees should be pruned in the dormant season and it should be of such severity as to regulate the bearing area without producing a vegetative condition of the trees. Over-bearing of the trees should be avoided by the proper thinning of the fruit.

\section{SUMMARY}

The investigations reported here are concerned with the influence of summer and dormant pruning, ringing, and partial defoliation with or without the application of nitrate of soda on the formation, composition, and growth of peach fruit buds in relation to their hardiness.

The two varieties Greensboro and Salwey were used for these studies as the former is hardy and the latter tender in the bud. The Greensboro forms a high and the Salwey a low percentage of fruit buds.

The practices used in these investigations had very little or no influence on fruit-bud formation on the Greensboro. Applications of nitrate of soda increased and summer pruning decrcased fruit-bud formation on the Salvey. Ringing the branches about the middle of June or partial defoliation done in August had little effect on the formation of fruit buds on the Salwey. Fruit-bud formation had probably taken place before the trees were ringed or defoliated. Fruit-bud formation was found to be highly correlated with the length of the shoot on which the buds are borne. This correlation is positive with the Greensboro and negative with the Salwey.

There was a high degree of negative correlation between the hardiness of the fruit buds and the length of the shoots on which they were borne. The buds produced on the basal portions of the shoots 
were hardier than those near the terminals. The practices that stimulated the growth of the trees caused the buds to be tender.

The results show that it was not possible by the treatments used to increase the hardiness of the Salwey fruit buds so that they were as hardy as those of the Greensboro.

Dormant or summer pruning decreased the hardiness of the fruit buds. Fertilization with nitrate of soda alone or in addition to pruning in most instances caused the buds to be susceptible to winter injury. The resistance of the buds to low temperatures was increased by ringing the branches about the middle of June. The results showed that partial defoliation reduced the hardiness of the buds.

During the winter about one-third of the tips of the shoots of the partially defoliated branches were winter killed. This injury was more severe on the trees that had also been fertilized with nitrate of soda. These results show that the shoots were, in this case, as tender or even more susceptible to injury than the fruit buds.

Evidence presented has shown that the killing of the pistils of peach buds by low temperatures in late winter may seriously curtail the prospects of a fruit crop. In some instances the pistils of the buds of ringed peach trees were less subject to injury than was the case when the branches were not girdled.

Partial defoliation or dormant or summer pruning with or without the application of nitrate of soda increased the water content of the buds. The effect of ringing the main branches was to reduce the percentage of water in the buds above the rings. The percentage of moisture in the buds was not constant but varied with the weather conditions during the winter. In warm weather the buds gained and in freezing weather they lost water. There was a high degree of negative correlation between the percentage of moisture in the buds and their hardiness.

The practices of partial defoliation, dormant or summer pruning, and nitrate of soda applications increased the percentage of total nitrogen contained in the buds. There was some indication that the percentage of nitrogen increased in the buds as the winter advanced, as it was slightly higher in late winter than earlier. Ringing the main branches was very effective in reducing the percentage of total nitrogen in the buds during one of the two years in which this was studied. A high degree of negative correlation existed between the total nitrogen content of the buds and their resistance to freezing injury. The water content of the buds was positively correlated with the percentage of nitrogen contained in them.

The buds increased in dry weight and total nitrogen during the winter months. The practices that stimulate the growth of the trees in the summer in which the buds are formed in most instances accelerated the gain in dry weight and total nitrogen of the buds during the winter. Coefficients of correlation have been calculated for one year between the percentage of buds alive and their total moisture and nitrogen contents. These coefficients were found to be $-.864 \pm .032$ and $-.679 \pm .068$, respectively. 
Wide differences in the carbohydrate composition of the buds of the Greensboro and Salwey were found. The fruit buds of the Greensboro were low in reducing, non-reducing, and total sugars and starch but high in alcohol-soluble non-sugars and hemicellulose, while those of the Salwey were high in all sugars and starch but low in alcoholsoluble non-sugars and hemicellulose. Pruning or applications of nitrogen did not alter appreciably the carbohyclrate composition of the buds. Ringing reduced the percentage of total sugars largely through the effect on the non-reducing sugar and increased the percentage of alcohol-soluble non-sugars and hemicellulose. The buds from the ringed branches of the Salwey approached the carbohydrate composition of the normal Greensboro trees. The evidence points to the conclusion that the food reserves of the Salwey fruit buds are in forms more readily available for growth and metabolic processes than those of the hardy Greensboro.

Histological studies showed that the fruit buds of both varieties developed during the winter months. The buds of the Salwey made the more rapid development, not only in the diameter of the naked buds but also in the differentiation of the pollen. The buds from the ringed trees made the least and those from the partially defoliated branches the greatest gain in diameter during this period. In general, ringing retarded and partial defoliation accelerated the development of pollen, with the buds of the check trees taking an intermediate position. Buds from the terminal portions of the shoots were generally more advanced than those from the basal regions of the same shoots as measured by pollen differentiation. There appears to be a high degree of positive correlation between the growth of the buds and their water, nitrogen, and soluble carbohydrate content. This is the explanation offered for the differences in the growth of the buds taken from variously treated trees or from different regions on the same shoot.

The data indicate that the effect of producing a crop of fruit is to reduce the hardiness of the buds. This is believed to be due to the removal of food materials in the fruit which are not replaced before leaf fall.

The greatest degree of hardiness of peach buds within a variety was found in those cases where there was the greatest storage of food. 


\section{BIBLIOGRAPHY}

(i) Авво'т', $U$.

1923. CHEMICAL CHANGES AT BEGINNING AND ENDING OF REST PERIOD IN APPLE AND PEACH. Bot. Gaz. 76: 167-184.

(2) Akerman, Ake, and Johannson, H.

1917. BEITRAEgE ZUR KENNTNIS DER KAELTERESISTENZ DES WINTERWEIZENS. Ztschr. Pflanzenzucht. 5: 349-356.

(3) Anderson, A. G., and Hooker, H. D.

1927. SOLL TREATMENTS AND SEASONAL CHEMICAL CHANGES IN THE SOUR Cherry. Mo. Agr. Exp. Sta. Res. Bul. 108.

(4) APELT, A.

1909. NeUE UNTERSUCHUNGEN LEBER DEN KAELTETOD DER KARTOFFEL. Cohn's Beitr. Biol. Pflanz. $9: 215-262$.

(5) Askenasy, E.

1877. Ueber DIE JAEHRliche PERIOD DER KNOSPEN. Bot. Zeitung 35:793-846.

(6) AUCHTER, E. C.

1923. IS THERE NORMALLY A CROSS TRANSFER OF FOODS, WATER AND MINERal Nutrients in woody Plants? Md. Agr. Exp. Sta. Bull. 257.

(7) Beach, S. A., and Allen, F. W.

1915. HARDINESS IN THE APPLE AS CORRELATED WITH STRUCTURE AND composition. Iowa Agr. Exp. Sta. Res. Bul. 21.

(S) BLACKMAN, F. F.

1909. vegEtation AND Frost. New Phytol. 8:354-363.

(9) Blake, M. A., and Farley, A. J.

1911. Winter Killing of PEACH Buns. N. J. Agr. Exp. Sta. Rept. 32:66-68.

(10) - and Connors, C. H.

1916. RePort of the department of horticulture. N. J. Agr. Exp. Sta. Rept. $37: 71-72$.

(11) BRAdFord, F. C.

1922. OBSERVATIONS ON WINTER INJURY. 1. EARLY AND LATE WINTER INJury. Mo. Agr. Exp. Sta. Res. Bul. 56.

(12) - and Cardinell, H. A.

1926. eighty winters in michigan orchards. Mich. Agr. Exp. Sta. Spec. Bul. 149.

(13) CARrICK, D. B.

1920. RESISTANCE OF THE ROOTS OF SOME FRUIT SPECIES TO LOW TEMPERAtures. Cornell Univ. Agr. Exp. Sta. Mem. 36.

(I5) CHANDLER, W. H.

1907. THE WINTER KILLING OF PEACH BLDS AS INFLUENCED BY PREVIOUS treatment. Mo. Agr. Exp. Sta. Bul. 74.

(18) Cooper, J. R., and Wiggans, C. B.

1926. A PRELIMINARY REPORT ON EXPERIMENTS WITH FER'TILIZERS FOR PEACH Trees. Ark. Agr. Exp. Sta. Bul. 202.

(19) Craig, J.

1897. FRUIT BUDS OF PEACHES AND PLUMS-THEIR RELATIVE HARDINESS. Canada Exp. Farms Rept. 1896:153. 160. 
(20) Crane, H. L.

1924. EXPERIMENT's in FERTILIZING PEACII trees. W. Va. Agr. Exp. Sta. Bul. 183.

(21)

1927. Some results of top ReNewal of OLD PEACI Trees. Proc. Amer. Soc. Hort. Sei. $24: 248-252$.

(22) Curtis, O. F.

1920. THE UPWARD TRANSLOCATION OF FOOI IN WOODY PLANTS. I. TISSUES CONCERNED in translocation. Amer. Jour. Bot. $7: 101-124$.

1920. TIIE UPWARD TRANSLOCATION OF FOOD IN WOODY PLANTS. II. IS THERE NORMALLY AN UPWARD TRANSFER OF STORAGE FOOD FROM THE ROOTS OR TRUNK TO THE GROWING SHOOTS? Amer. Jour. Bot. $7: 286-295$.

1923. THE EFFECT OF RINGING A S'TEM ON THE UPWARD TRANSFER OF NITROGEN AND ASH constituents. Amer. Jour. Bot. 10:361-382.

(25) D'Arsonval, M.

1901. LA PRESSION OSMOTIQUE ET SON ROLE DE DEFENSE CONTRA LE FROID dans la cellule vivan'te. Comp. Rend. Acad. Sei. Paris 133:84-86.

(26) Davis, M. B.

1915. WINTER KILLING OF CHERRY BUDS. REPORT FROM THE DIVISION OF HORTICulture. Canada Dept. Agr. Rept. 1914:500-501.

(27) DeLong, W. A.

1928. PENTOSAN CONTENT IN RELATION TO WINTER HARDINESS IN THE APPLE. Sci. Agr. 8:512-523.

(28) Dorsey, M. J., and Strausbaugh, P. D.

1923. PLUM INVESTIGATIONS. I. WINTER INJURY TO PLUM DURING DORMANCY. Bot. Gaz. $76: 113-143$.

(29) Doyle, Joseph, and Clinch, Phyllis.

1926. THE PENTOSAN THEORY OF COLD RESISTANCE APPLIED TO CONIFERS. Sci. Proc. Roy. Dublin Soc. 18:219-235.

1926. THE DEHYDRATION RATES OF CONIFER LEAVES IN RELATION TO PENTOSAN Content. Sei. Proe. Roy. Dublin Soc. 18:265-275.

(31) Duifamel du Monceau, H. L., and Buffon, G. L. L.

1740. OBSERVATIONS DES DIFFERENTS EFFECTS QUE PRODUISENT SUR LES VEGETAUX LES GRANDES GEIEES D'IIIVER ET PETITES GELEES DU PRINTEMPS. Mem. Math et Phys. Acad. Roy. Soc. Paris 1737:237-29S.

(32) Dunn, Stuart, and Bakke, A. L.

1926. ADSORPTION AS A MEANS OF DLTERMINING RELATIVE IIARDINESS IN APPLE. Plant Physiol. I:165-178.

(33) EMERSON, R. A.

1903. eXPeriments in orchard culture. Neb. Agr. Exp. Sta. Bul. 79.

1906. Tite Relation of Early maturity to ilardiness in trees. Neb. Agr. Exp. Sta. Ann. Rept. 19:101-110.

(35) EMERY, S. M.

1899. Sixtil annual report. Montana Agr. Exp. Sta. Bul. 24.

(36) Gladwin, F. E.

1917. Winter injury of grapes. New York Agt. Exp. Sta. Bul. 433.

(37) GOEPPERT, H. R.

1830. UEBER DIE WARMENT'WICKELUNG IN DEN PFLANZEN:DEREN GEFRIEREN UND DIE SCHUTZMITTEL GEGEN DASSE? BE. Breslau. 
(38) GORKE, H.

1907. UEBER CHEMISChE VORGAENGE BEIM ERFRIEREN DER PFLANZEN. Landw. Versuch. Sta. 65:149-160.

(39) Green, W. J., and Ballou, F. H.

1904. Winter killing of PeAch trees. Ohio Agr. Exp. Sta. Bul. 157.

(40) Greene, L.

1918. Horticulture. Ind. Agr. Exp. Sta. Rept. 31:46.

(41) HaAs, A. R. C., and Halma, F. F.

1928. PHIYSICAL AND CHEMICAL CHARACTERISTICS OF EXPRESSED CITRUS LEAF SAP AND THEIR SIGNIFICANCE. Bot. Gaz. 85:457-461.

(42) Harris, J. A., and Poponoe, W.

1916. FREEZING POINT LOWERING OF TIIE LEAF SAP OF THE IIORTICULTURAL TYPES OF PERSEA AMERIC̣ANA. Jour. Agr. Res. 7:261-268.

(43) HARveY, R. B.

1918. HARDENING PROCESSES IN PLANTS AND DEVELOPMENTS FROM FROST INJURY. Jour. Agr. Res. 15:83-112.

(44) Harvey, E. M.

1923. A STUDY OF TIIE GROWTH IN SUMMER SHOOTS OF THE APPLE WITH S . ECIAL CONSIDERATION OF THE ROLE OF CARBOIIYDRATES AND NITROGEN. Ore. Agr. Exp. Sta. Bul. 200.

(45) - - a , and MurneeK, A. E.

1921. THE RELATION OF CARBOHYDRATES AND NITROGEN TO TIIE BEHAVIOR OF Apple spurs. Ore. Agr. Exp. Sta. Bul. 176.

(46) Hildreth, A. C.

1926. DETERMINATION OF HARDINESS IN APPLE VARIETIES AND THE RELATION of some factors to cold Resistance. Minn. Agr. Exp. Sta. Tech. Bul. 42.

(47) Hodson, F. R.

1923. OBSERVATIONS ON THE REST PERIOD OF DECIDUOUS FRUIT TREES IN A mild Climate. Proe. Amer. Soe. Hort. Sei. 20:151-155.

(48) HOOKER, H. D.

1920. PEntosan CONTENT in Relation to Winter haRdiness. Proc. Amer. Soc. Hort. Sei. $17: 204: 207$.

(50) Howard, W L.

1909. Protecting orciards against Frosts and freezes. Mo. Agr. Exp. Sta. Circ. 35.

1910. AN EXPerimental study of the Rest PERIOd in Plants. Mo. Agr. Exp. Sta. Res. Bul. 1.

1915. AN EXPERIMENTAI. STUDY OF THE REST PERIOD IN PLANTS. PHYSIOLOGical changes accompanying breaking of the rest Period. Mo. Agr. Exp. Sta. Res. Bul. 21.

(53) Johnson, E. S.

1919. AN INDEx OF IIARDINESS IN PEACH BUDS. Amer. Jour. Bot. 6:373-379.

(55) KnOwLton, H. E.

1923. MOISTURE RELATIONS OF PEACH BUDS DURING THE WINTER AND SPRING. Md. Agr. Exp. Sta. Bul. 255.

1921. A Preliminary report on inalf tree fertilization. Proc. Amer. Soc. Hort. Sei. $18: 148-149$.

(56) - and Dorsey, M. J.

1927. A STUDY OF TIIE HARDINESS OF THE FRUIT BUDS OF THE PEACH. W. V a. Agr. Exp. Sta. Bul. 211. 
(57) LepesciIKIN, W.

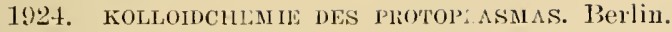

(5is) LibForss, B.

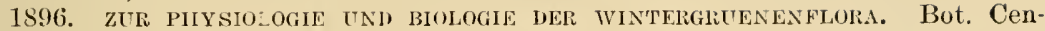
tralbl. $68: 33-44$.

(59) LoTT, R. V.

1926. CORRELATION OF CIIEMICAL COMPOSITION WITII IIARDINESS IN BRAMBLES. Mo. Agr. Exp. Sta. Res. Bul. 95.

(60) Macoun, W. T.

1907. REPORT OF THE horticulturist. Canada Dept. Agr. Central Exp. Farms 1906:110-112.

(61) Martin, JoHN H.

1927. Comparative studies of Winter hardiness in wheat. Jour. Agr. Res. $35: 493-535$.

(62) Maxinow, N. A.

1912. CMEMISCHE SCHUTZMITTEL DER PFLANZEN GEGEN ERFRIEREN. Ber. d. deut. Bot. Gesell. 30:52-65.

(63) MoLisch, H.

1897. UNTERSUCIIUNGEN UEBER DAS ERFRIEREN DER PFLANZEN. Jena.

(64) 1907. UEBER DAS GEFRIEREN IN KOLLOIDEN. Flora. 97:121-122.

(65) Mueller-Thurgau, $\mathrm{H}$.

18S0. UEBER DAS GEFRIEREN UND ERFRIEREN DER PF JANZEN. Landw. Jahrb. $9: 133-189$.

(66) 1886. UEBER DAS GEFRIEREN UND ERFRIEREN DER PFLANZEN. Landw. Jahrb. $15: 453-610$.

(67) NewTON, ROBERT

1922. A COMPARATIVE STUDY OF WINTER WHEAT VARIETIES WITII ESPECIAL REFERENCE TO Winter Killing. Jour. Agr. Sei. 12:1-19.

1924. COLLOIDAL PROPERTIES OF WINTER WHEAT PLANTS IN RELATION TO Frost IIARDINESS. Jour. Agr. Sci. 14:178-191.

1924. THE NATURE AND PRACTICAL MEASUREMENT OF FROST RESISTANCE IN Winter wheat. Univ. Alberta Col. Agr. Res. Bul. 1.

(70) OHLWEILER, W. W.

1912. THE RELATION BETWEEN THE DENSITY OF CELI, SAPS AND THE FREEZING POIN'T of LEaves. Mo. Bot. Gard. Rept. 23:101-131.

(71) Pearson, KarL.

1914. TABLES FOR STATISTICIANS AND BIOMETRICIANS. I-LXXXIII. 1-143.

(72) Pojarkova, Antonina. -

1924. RESERVESTOFFE UND KAELTERESISTENZ BEI IIOLZPFLANZEN. Ber. d. deut. Bot. Gesell. $42: 120-429$.

(73) POTTER, G. F.

1924. EXPERINIENTS ON THE RESISTANCE OF APPLE ROOTS TO LOW TEMPERAtures. New Hamp. Agr. Exp. Sta. Tech. Bul. 27.

(74) Proebsting, E. L.

1925. THE RELATION OF STORED FOOD TO CAMBIAL ACTIVITY IN THE APPLE. Hilgardia 1:81-106.

(75) REIN, R.

1908. UNTERSUCHUNGEN UTERER DEN KAELTETOD DER PFLANZEN. Ztschr, fuer Naturwiss. 80:1-38.

(76) RoBerts, R. H.

1917. Winter injury to cherry blossom buds. Proc. Amer. Soc. Hort. Sci. 14:105-110. 
(77) $\operatorname{RosA}$, J. T. JR.

1921. INVESTIGATIONS ON TIIE IIIRDENING PROCESS IN VEGETABIL PLANTS. Mo. Agr. Exp. Sta. Res. Bul. 48.

(T\&) SaCHS, J.

1860. UNTERSUCHUNGex UeBfr DAS ERFRIEREN DER PFLANZEN. Landw. Versuch. Sta. $2: 167-201$.

(79) Salmon, S. C., and Fleming, F. L.

1918. RELATION OF TIIE DENSITY OF TIIE CELL SAP TO WINTER IIARDINESS IN SMall grains. Jour. Agr. Res. 13:497-506.

(80) Schaffnit, E.

1910. STUDIEN UEBER DEN EINFLU iS NEIDERER TEMPERATUREN AUF DIE PFLANZELICIIE ZEJ.LF. Mitt. Kaiser Wilhelms Inst. Landw. Bomberg 3:93-144.

(81) Schander, R., and Schaffnit, E.

1918. UNTERSUCHUNGEN UEBER DAS AUSWINTER DES GETRIEBES. Landw. Jahrb. 52:1-66.

(82) ShutT, F. F.

1903. ON TIIE RELATION OF MOISTURE-CONTENT TO HARDINESS IN APPLE TWIGS. Proc. and Trans. Roy. Soc. Can. 9:149-153.

(83) Sinz, E.

1914. BEZIEIIUNGEN ZWISCIIEN TROCIIENSUBSTANZ UND WINTERFESTIGKEIT BEI VERSCHIEDEN WINTERWEIZEN-VARIETAETEN. Journ. fuer Landw. 62:301-¿35.

(84) Strausbaugh, P. D.

1921. DORMANCY AND HARDINESS in THE PLUM. Bot. Gaz. 71:337-357.

(85) Summers, F.

1923. FACTORS GOVEINING FRUIT BUD FORMATION. V. FURTIIER EXPERIMENTS UPON THE RINGING AND NOTCHING OF FRUIT TREES. Jour. Bath and West. and South. Counties Soc. $17: 140-144$.

(96) 1923. FACTORS GOVERNING FRUIT BUD FORMATION. VI. THE STIMULATION OF BUD GROWTII IN CUTTINGS BY INORganic AND ORganic solutions. Jour. Bath. and West. and South. Counties Soc. $17: 145-149$.

(87) Thayer, Paul.

1916. Winter killing of Peacil Buds. Ohio Agr. Exp. Sta. Mon. Bul. 1:311312 .

(8S) Webber, H. J., and others.

1919. A STUdy OF THE EFFECTS OF FREEZES ON CITRUS IN CALIFORNiA. Cal. Agr. Exp. Sta. Bul. 304.

(89) West, Frank L., and Edlefsen, N. E.

1921. FREEZING OF FRUIT BUds. Jour. Agr. Res. 30:655-662.

(90) WhitTen, J. C.

1899. THE RELATION OF COIOR TO TIIE GROWTII OF FRUIT BUDS OF TIIE PEACII ON SUnNy days in winter. Proc. Amer. Pom. Soc. $26: 44-48$.

(91) WiEgaND, K. M.

1906. THE OCCURRENCE OF ICE IN PLANT mssue. Plant World 9:25-39.

1906. SOME STUDIES REGARDING THE BIOLOGY OF BUDS AND TWIGS IN WINTER. Bot. Gaz. $41: 373-424$.

(93) WinkLeR, A.

1913. UEBER DEN EINFLUSS DER AUSSENBEDINGUNGEN AUF DIE KAETTERESISTENZ AUSDAUERNDER GEWAECIISE. Jahrb. Wiss. Bot. 52:467-506.

(94) Zacharowa, T. M.

1925. UEBER EINFLUSS NIEDRIGER TEMPERATUREN AUF DiE PFLANZEN. Jahrb.

Wiss. Bot. $65: 61-87$. 



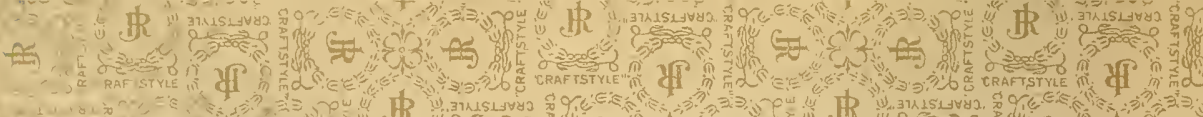
य.

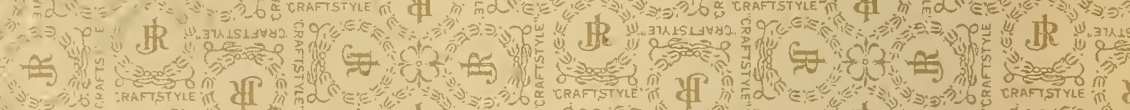
Th 2. 4 . one

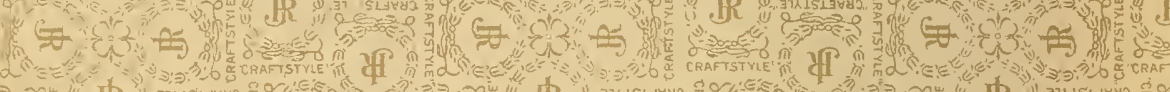

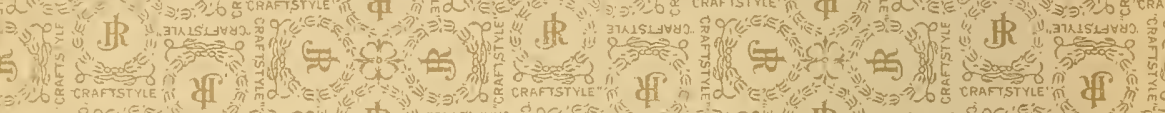
Gon P 20

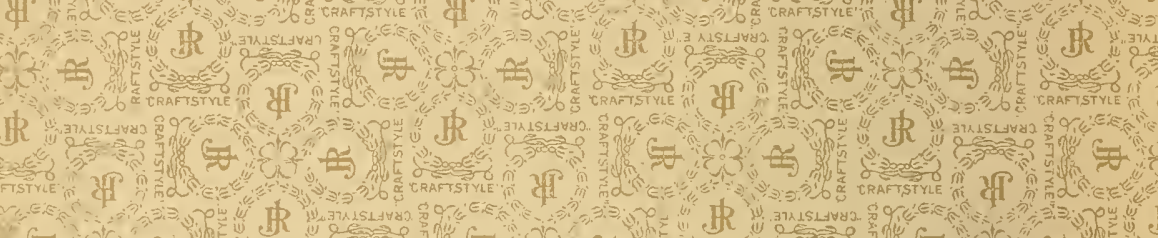

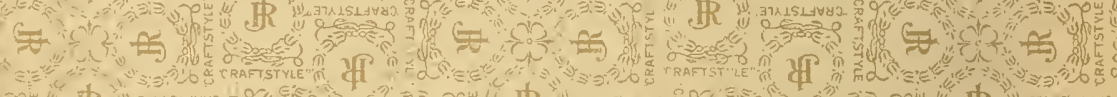

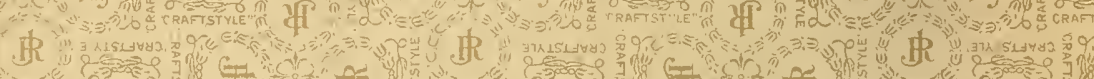

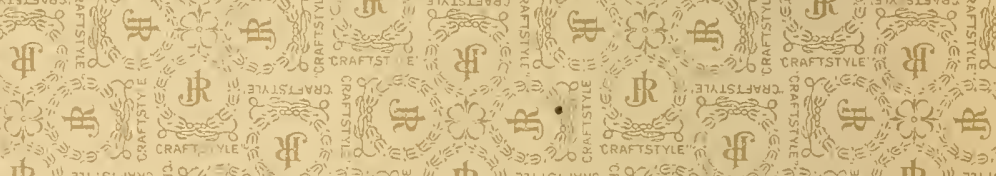
K

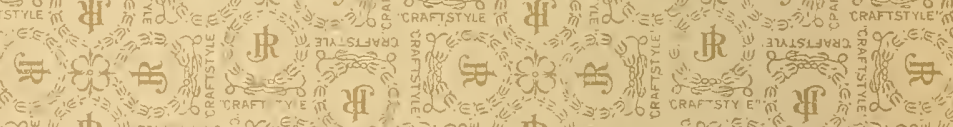

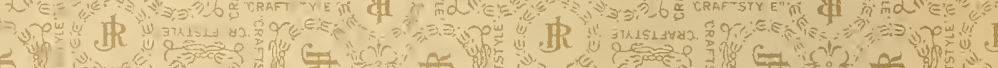

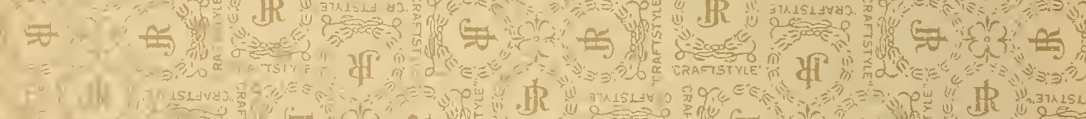

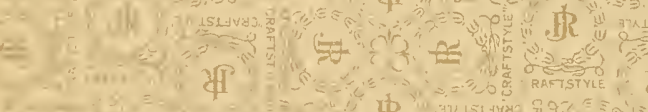

यi

if

$\Psi$

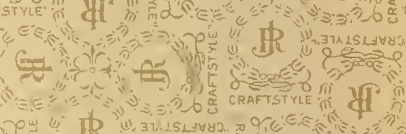

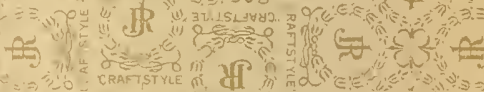

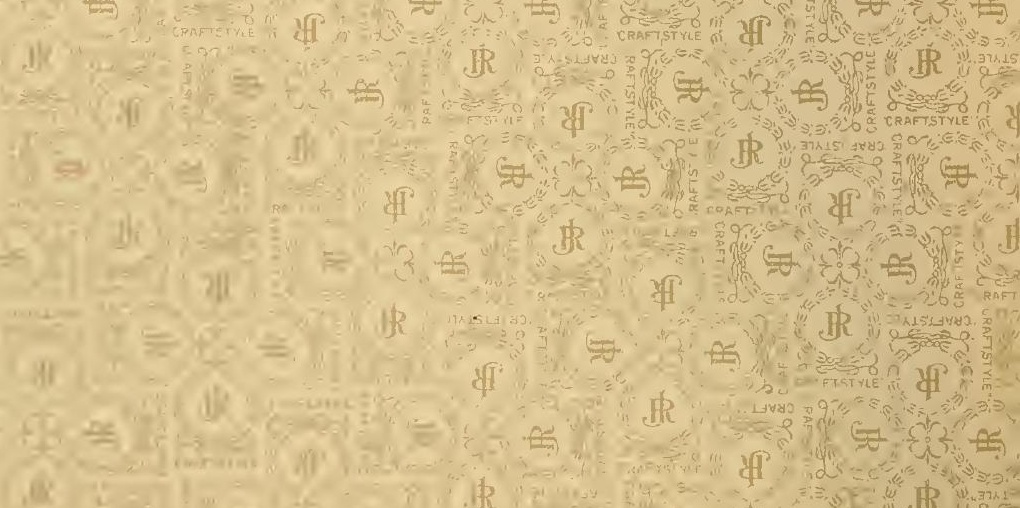

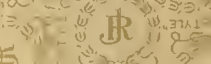




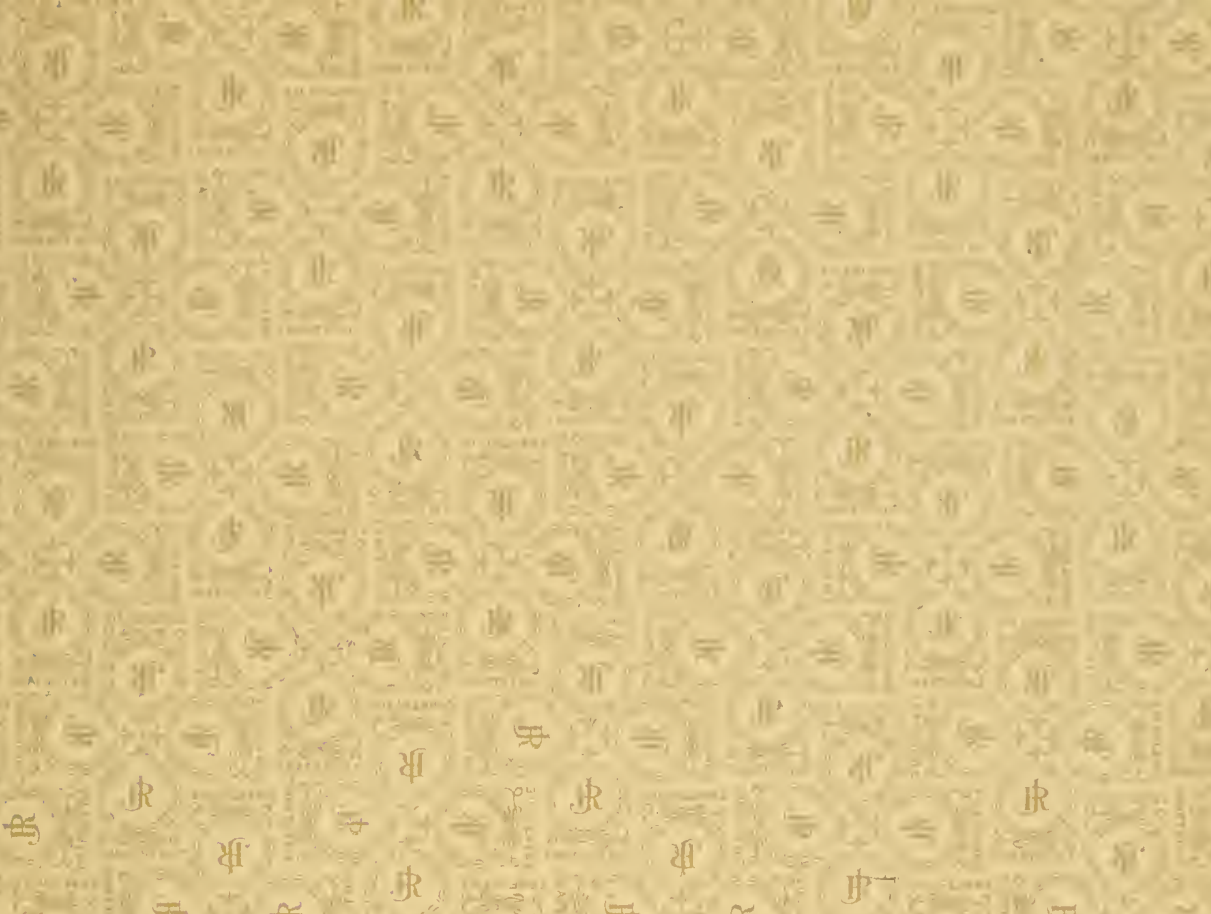

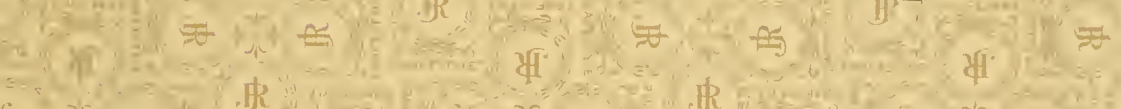
G.

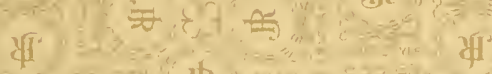

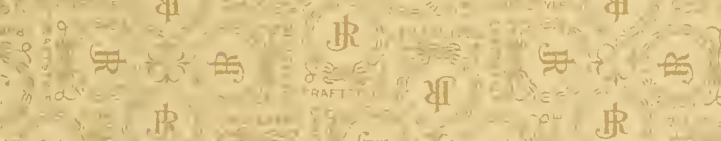

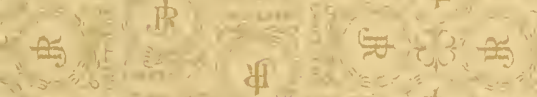
य. SE 边 $x^{3}+x^{2}-x^{2} \cdot y^{2}=$ 束 \& $\operatorname{son}^{2}$

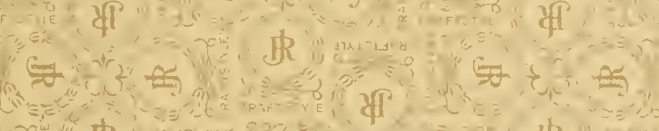

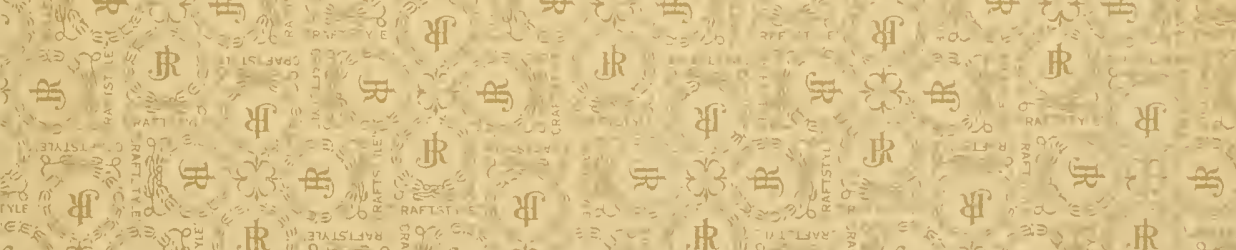

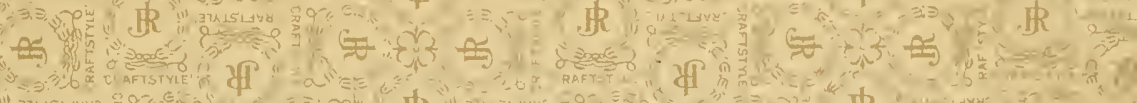

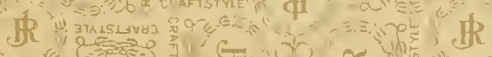
$5)^{2}+1$

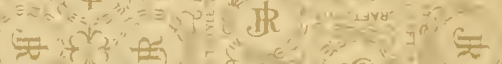


. 